\title{
Preliminary Analysis of \\ Treatment Strategies for \\ Transuranic Wastes from Reprocessing Plants
}

\author{
W. A. Ross \\ K. J. Schneider \\ J. L. Swanson \\ K. M. Yasutake \\ R. P. Allen
}

July 1985

Prepared for the U.S. Department of Energy under Contract DE-AC06-76RLO 1830

Pacific Northwest Laboratory

Operated for the U.S. Department of Energy by Battelle Memorial Institute 


\title{
DISCLAIMER
}

This report was prepared as an account of work sponsored by an agency of the United States Government. Neither the United States Government nor any agency thereof, nor any of their employees, makes any warranty, express or implied, or assumes any legal liability or responsibility for the accuracy, completeness, or usefulness of any information, apparatus, product, or process disclosed, or represents that its use would not infringe privately owned rights. Reference herein to any specific commercial product, process, or service by trade name, trademark, manufacturer, or otherwise, does not necessarily constitute or imply its endorsement, recommendation, or favoring by the United States Government or any agency thereof. The views and opinions of authors expressed herein do not necessarily state or reflect those of the United States Government or any agency thereof.

\author{
PACIFIC NORTHWEST LABORATORY \\ operated by \\ BATJELLE \\ for the \\ UNITED STATES DEPARTMENT OF ENERGY \\ under Contract DE-AC06-76RLO 1830
}

\begin{tabular}{|c|c|}
\hline \multicolumn{2}{|c|}{ Printed in the United States of America } \\
\hline \multirow{2}{*}{\multicolumn{2}{|c|}{$\begin{array}{l}\text { Available from } \\
\text { National Technical Information Service }\end{array}$}} \\
\hline & \\
\hline \multirow{3}{*}{\multicolumn{2}{|c|}{$\begin{array}{c}\text { United States Department of Commerce } \\
\text { 5285 Port Royal Road } \\
\text { Springfield, Virginia } 22161\end{array}$}} \\
\hline & \\
\hline & \\
\hline \multirow{2}{*}{\multicolumn{2}{|c|}{$\begin{array}{l}\text { NTIS Price Codes } \\
\text { Microfiche A01 }\end{array}$}} \\
\hline & \\
\hline \multicolumn{2}{|c|}{ Printed Copy } \\
\hline & Price \\
\hline Pages & Codes \\
\hline $001-025$ & $\mathrm{~A} 02$ \\
\hline 026-050 & $\mathrm{A} 03$ \\
\hline 051-075 & A04 \\
\hline 076-100 & A05 \\
\hline $101-125$ & $A 06$ \\
\hline $126-150$ & A07 \\
\hline $151-175$ & $A 06$ \\
\hline $176-200$ & $\mathrm{~A} 09$ \\
\hline $201-225$ & A010 \\
\hline $226-250$ & A011 \\
\hline $251-275$ & A012 \\
\hline $276-300$ & $A 013$ \\
\hline
\end{tabular}


PNL -5130

IJC-70

PRELIMINARY ANALYSIS OF TREATMENT STRATEGIES FOR

TRANSURANIC WASTES FROM REPROCESSING PLANTS
W. A. Ross
K. J. Schneider
J. L. Swanson
K. M. Yasutake
R. P. Allen

July 1985

Prepared for

the U.S. Department of Energy

under Contract DE-AC06-76RLO 1830

Pacific Northwest Laboratory

Richland, Washington 9935? 
$+$ 


\section{ACKNOWLEDGMENTS}

The authors would like to acknowledge the work completed in a related study funded by the II.S. Department of Energy's Office of Civilian Radioactive Waste Management (OCRWM) in the Waste Management Systems Studies at Pacific Northwest Lahoratory. A close working relationship was maintained between the two studies, and the waste characterization and economic cost data utilized in this study were produced in the OCRWM study.

We would also like to acknowledge the fine support provided hy Susan king and Donna Kuick in editing and coordinating the publication of the drafts and final document. The preparation of this report required many hours of extra effort on their part and on the part of Marlene Hale's word processing team. We would also like to thank those who took time from their husy scherules to review drafts of the report. 



\section{ABSTRACT}

This document provides a comparison of six treatment options for transuranic wastes (TRIJW) resulting from the reprocessing of commercial spent fuel. Projected transuranic waste streams from the Barnwell Nuclear Fuel Plant (BNFP), the reference fuel reprocessing plant in this report, were grouped into the five categories of hulls and hardware, failed equipment, filters, flourinator solids, and general process trash (GPT) and sample and analytical cell (SAC) wastes.

Six potential treatment options were selected for the five categories of waste. These options represent six basic treatment objectives: 1) no treatment, 2) minimum treatment (compaction), 3) minimum number of processes and products (cementing or grouting), 4) maximum volume reduction without. decontamination (melting, incinerating, hot pressing), 5) maximum volume reduction with decontamination (decontamination, treatment of residues), and 6) noncombustible waste forms (melting, incinerating, cementing). Schemes for treatment of each waste type were selected and developed for each treatment option and each type of waste. From these schemes, transuranic waste volumes were found to vary from $1 \mathrm{~m}^{3} / \mathrm{MTII}$ for no treatment to as $10 \mathrm{w}$ as $0.02 \mathrm{~m}^{3} / \mathrm{MTU}$.

Rased on conceptual design requirements, life-cycle costs were estimated for treatment plus on-site storage, transportation, and disposal of hoth highlevel and transuranic wastes (and incremental low-level wastes) from $70,000 \mathrm{MTU}$. For all treatment cases (0ptions 2 through 6), the additional costs for treatment were more than compensated for by the reduced cost of transportation and disposal in amounts ranging from $\$ 0.1$ hillion to $\$ 1.7$ hillion (in 1983 undiscounted dollars).

The study concludes that extensive treatment is warranted from both cost and waste form characteristics considerations, and that the characteristics of most of the processing systems used are acceptable. The study recommends that additional combinations of treatment methods or strategies he evaluated and that in the interim, melting, incineration, and cementing he further developed for commercial TRIJW. 


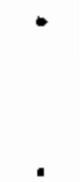




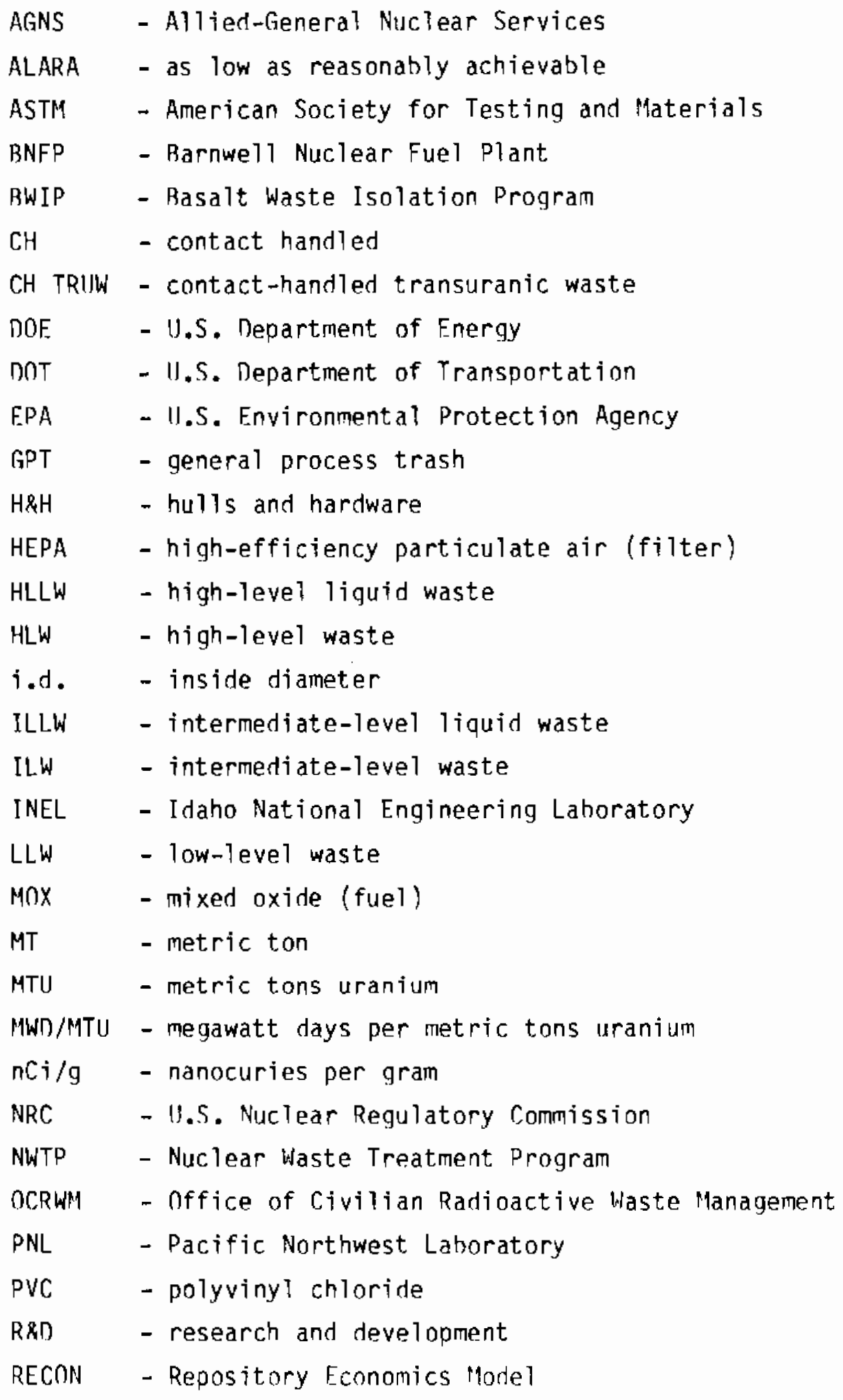




$\begin{array}{ll}\text { RH } & \text { - remote handled } \\ \text { RH TRUW } & \text { - remote-handled transuranic waste } \\ \text { SAC } & \text { - sample and analytical cell (waste) } \\ \text { TRII } & \text { - transuranic } \\ \text { TRIJW } & \text { - transuranic waste } \\ \text { TRIJPACT } & \text { - Transuranic Package Transporter } \\ \text { WAC } & \text { - Waste Acceptance Criteria } \\ \text { WIPP } & \text { - Waste Isolation Pilot Plant }\end{array}$


ACKNOWLFDGMENTS

iji

ARSTRACT $\ldots \ldots \ldots \ldots \ldots \ldots \ldots \ldots \ldots \ldots \ldots \ldots \ldots \ldots \ldots \ldots \ldots \ldots \ldots \ldots \ldots \ldots \ldots \ldots$

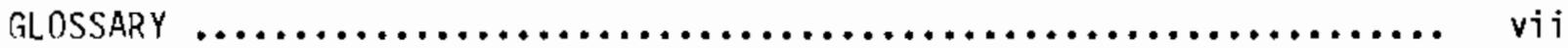

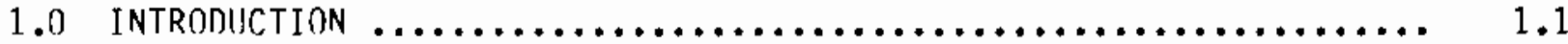

1.1 REFERENCE.................................. 1.2

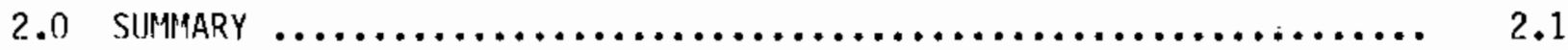

2.1 REFERENCES $\ldots \ldots \ldots \ldots \ldots \ldots \ldots \ldots \ldots \ldots \ldots \ldots \ldots \ldots \ldots \ldots \ldots \ldots \ldots \ldots \ldots \ldots$

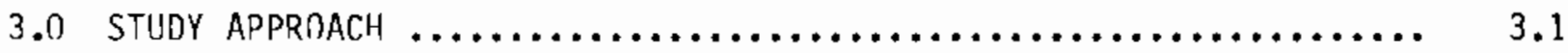

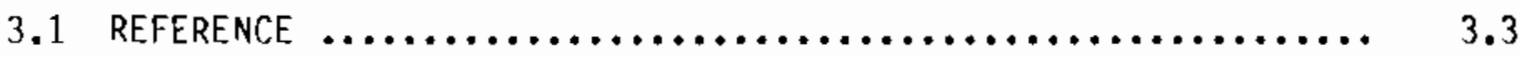

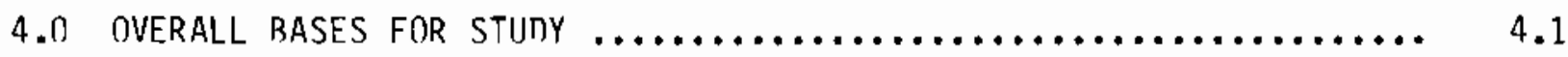

4.1 TECHNICAL BASES AND ASSUMPTIONS $\ldots \ldots \ldots \ldots \ldots \ldots \ldots \ldots \ldots \ldots \ldots \ldots \ldots \ldots \ldots \ldots$

4.2. REGILLATORY BACKGROUNI $\ldots \ldots \ldots \ldots \ldots \ldots \ldots \ldots \ldots \ldots \ldots \ldots \ldots \ldots \ldots \ldots \ldots \ldots \ldots \ldots$

4.2.1 Generally Applicable Regulations ............... 4.4

4.2.2 Regulations Relating to Release Rates from Repositories .............................. 4.5

4.2.3 Regulations Related to Other waste Form Characteristics

4.3 REFERENCES $\ldots \ldots \ldots \ldots \ldots \ldots \ldots \ldots \ldots \ldots \ldots \ldots \ldots \ldots \ldots \ldots \ldots \ldots \ldots \ldots . \ldots \ldots \ldots$

5.0 DEFINITION OF TRIW STREAMS $\ldots \ldots \ldots \ldots \ldots \ldots \ldots \ldots \ldots \ldots \ldots \ldots \ldots \ldots \ldots . . \ldots \ldots$

5.1 ORIGIN OF GENERAL TRIJW TYPES AT THE REFERENCE FIJEL REPROCESSING PLANT

5.2 BASES FOR TRIJ DESCRIPTIONS $\ldots \ldots \ldots \ldots \ldots \ldots \ldots \ldots \ldots \ldots \ldots \ldots \ldots \ldots$

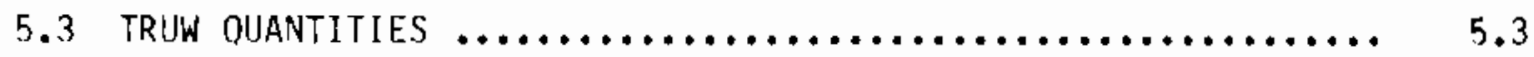

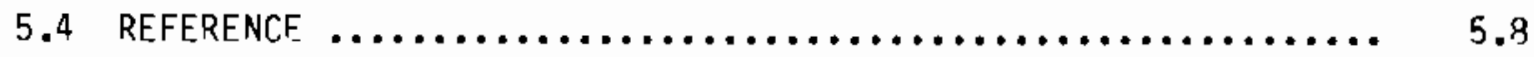

6.0 SELECTION OF WASTE TREATMENT OPTIONS $\ldots \ldots \ldots \ldots \ldots \ldots \ldots \ldots \ldots \ldots \ldots \ldots$

6.1 TREATMENT PROCESSES .......................... 6.1 
6.2 SELECTION OF tREATMENT BBJECTIVES $\ldots \ldots \ldots \ldots \ldots \ldots \ldots \ldots \ldots, \quad 5.4$

6.2.1 Option 1 -- No Treatment $\ldots \ldots \ldots \ldots \ldots \ldots \ldots \ldots \ldots \ldots \ldots \ldots \ldots, 6.4$

6.2.? Option 2 -- Minimum Treatment $\ldots \ldots \ldots \ldots \ldots \ldots \ldots \ldots . .6 .6 .6$

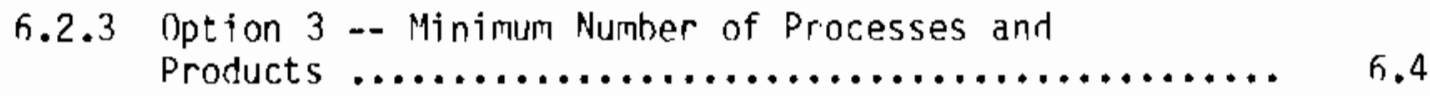

6.2.4 Option 4 -- Maximum Volume Reruction Without
Decontamination $\ldots \ldots \ldots \ldots \ldots \ldots \ldots \ldots \ldots \ldots \ldots \ldots \ldots \ldots \ldots \ldots \ldots$

6.2.5 Option 5 -- Maximum Volume Reduction with
Decontamination $\ldots \ldots \ldots \ldots \ldots \ldots \ldots \ldots \ldots \ldots \ldots \ldots \ldots \ldots \ldots \ldots \ldots \ldots$

6.2.6 Option 6 -- Noncomhustihle Waste Forms ............ 6.6

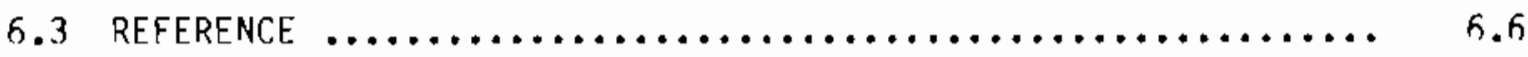

7.0 PROCESS DESCRIPTIONS AND WASTE OUANTITIES FOR THE SIX RASIC

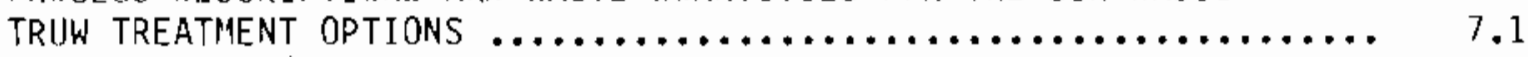

7.1 OPTION 1 - NO TREATMENT $\ldots \ldots \ldots \ldots \ldots \ldots \ldots \ldots \ldots \ldots \ldots \ldots \ldots \ldots \ldots \ldots \ldots \ldots \ldots . .1$

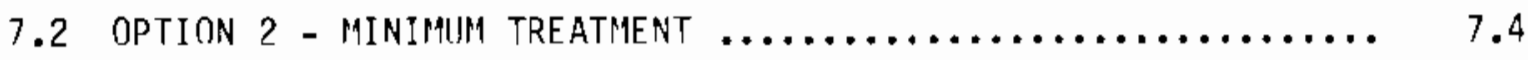

7.3 OPTION 3 - MINIMUM NIMABER OF PROCESSES AND PRODICTS $\ldots \ldots \ldots .7 .6$

7.4 DPTION 4 - MAXIMUM VOLLIME REDUCTION WITHOUT
DECONTAMINATION $\ldots \ldots \ldots \ldots \ldots \ldots \ldots \ldots \ldots \ldots \ldots \ldots \ldots \ldots \ldots \ldots$

7.5 OPTION 5 - MAXIMUM VOLIMME REDUCTION WITH DECONTAMINATION .... 7.13

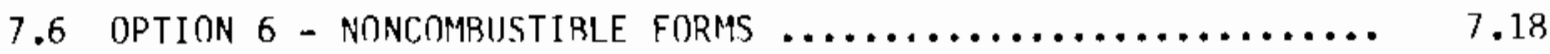

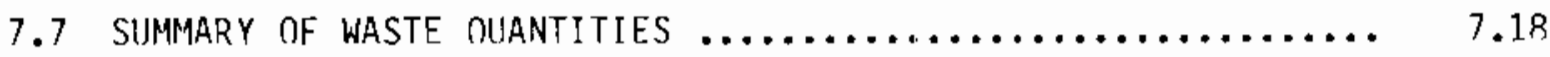

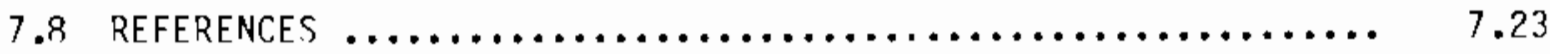

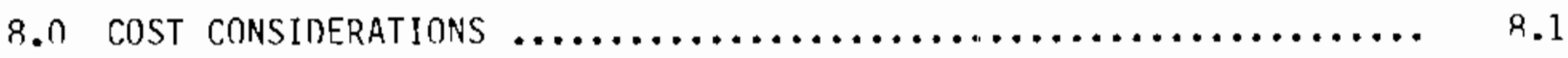

8.1 COST OF TRIJW TREATMENT FACILITIES $\ldots \ldots \ldots \ldots \ldots \ldots \ldots \ldots \ldots, 8.1$

8.1.1 Capital Costs for TRUW Treatment: Facilities ......... 8.1

8.1.2 Operating Costs for TRIJW Treatment Facilities ....... 8.3

8.1.3 Summary of TRIJ Treatment Facility Costs ........... 8.3

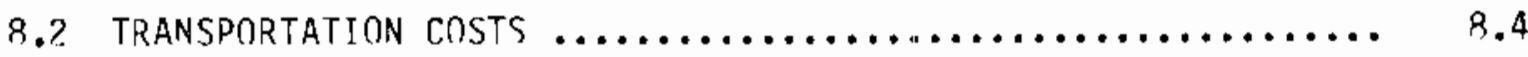


8.3 DISPOSAL COSTS $\ldots \ldots \ldots \ldots \ldots \ldots \ldots \ldots \ldots \ldots \ldots \ldots \ldots \ldots \ldots \ldots \ldots \ldots \ldots \ldots, 8.5$

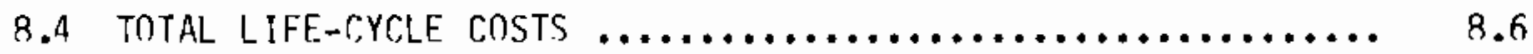

8.5 REFERENCES $\ldots \ldots \ldots \ldots \ldots \ldots \ldots \ldots \ldots \ldots \ldots \ldots \ldots \ldots \ldots \ldots \ldots \ldots \ldots \ldots, 8.8$

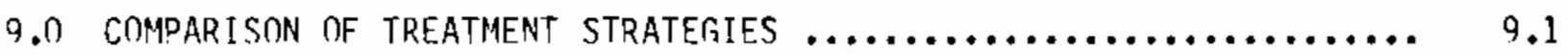

9.1 WASTE FORM CHARACTERISTICS $\ldots \ldots \ldots \ldots \ldots \ldots \ldots \ldots \ldots \ldots \ldots . . . .1$

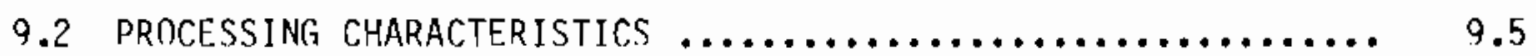

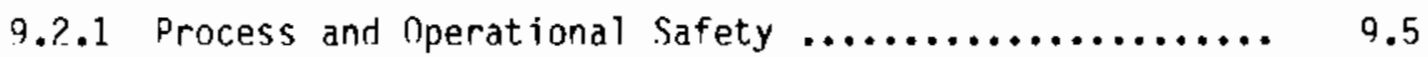

9.?.? Complexity of the Treatment System $. . . \ldots \ldots \ldots \ldots . . .6 .6$

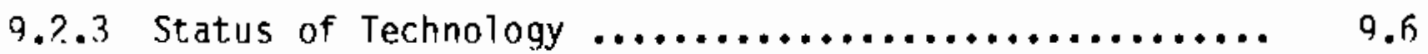

9.2.4 Flexibility of the Processes $\ldots \ldots \ldots \ldots \ldots \ldots \ldots \ldots . .9 .6$

9.2.5 Overall Evaluation of Processing Characteristics ..... 9.8

9.3 OVERALL COMPaRISON DF TREATMENT OPTIONS $\ldots \ldots \ldots \ldots \ldots \ldots . . .9 .9$

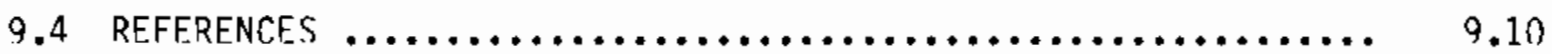

10.0 CONCLUISIONS ANO RECOMMENDATIONS $\ldots \ldots \ldots \ldots \ldots \ldots \ldots \ldots \ldots \ldots \ldots, 10.1$

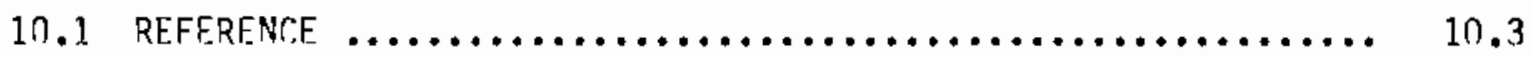

APPENIIX A - TRIWW CHARACTERISTICS BY WASTE TYPE $\ldots \ldots \ldots \ldots \ldots \ldots \ldots \ldots$ A.1

$\begin{aligned} \text { APPENDIX B } & \text { DETAILS OF THE ESTIMATION OF FINAL PROCESSEN } \\ \text { TRIJW DUANTITIES } \ldots \ldots \ldots \ldots \ldots \ldots \ldots \ldots \ldots \ldots \ldots \ldots \ldots \ldots \ldots \ldots \ldots \ldots \ldots & \text { B. } 1\end{aligned}$

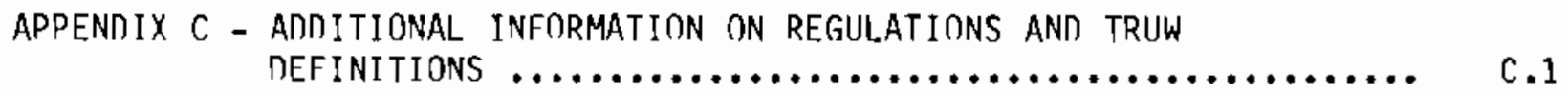

APPENNIX D - PROCESSING, TRANSPORTATION, ANO DISPOSAL

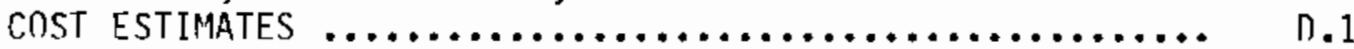

APPENDIX E - BARNWELL LOW-LEVEL RADIOACTIVE WASTE MISPOSAL FACILITY RATE SCHEOIULE EFFECTIVE JANUARY $1,1984 \ldots \ldots \ldots$... E.1

APPENIIX F - ADRITIONAL INFORMATION ON THE EVALUATION OF PROCESSING CHARACTERISTICS 


\section{FIGIJRES}

3.1 Major Steps in the TRtw Treatment Development Program .......... 3.1

3.2 Flow Chart for Strategy Evaluation $\ldots \ldots \ldots \ldots \ldots \ldots \ldots \ldots \ldots \ldots \ldots . . . \ldots$

7.1 Overall Process Flow Diagram for TRIJW Treatment $\ldots \ldots \ldots \ldots \ldots \ldots \ldots .3$

7.2 Process Flow Diagram for Option 1 - No Treatment ............ 7.4

7.3 Process and Equipment Flow Diagram for Option ? - Minimum

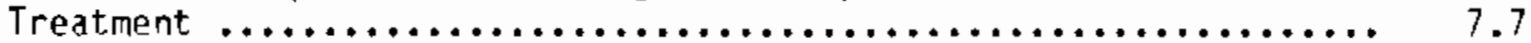

7.4 Process and Equipment Flow Diagram for Option 3 - Minimum

Number of Processes and Products ....................... 7.9

7.5 Equipment and Process Flow Diagram for Option 4 - Maximum Volume

Reduction Without Decontamination ...................... 7.12

7.6 Process and Equipment Flow Diagram for 0ption 5 - Maximum

Volume Reduction with Decontamination $\ldots \ldots \ldots \ldots \ldots \ldots \ldots \ldots \ldots . . .14$

7.7 Process and Equipment Flow Diagram for Option 6 - Noncombustible Waste Forms 
TARLES

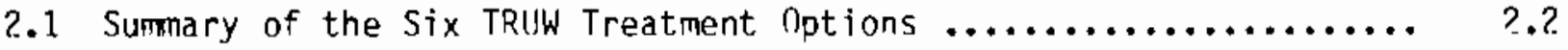

2.2 Annual Volumes of Treated Wastes from a $1,500 \mathrm{MTH} / \mathrm{yr}$

Reprocessing Plant for the Six TRLWW Treatment Options ........... 2.3

2.3 Costs for Treatment, Transportation, and nisposal of

TRIJW and Incremental LLW from 70,000 MTU of Reprocessed

Spent Fuel

2.4 Costs for Treatment, Transportation and nisposal of HLW, TRIJ, and Incremental LLW from 70,00ก MTU of Reprocessed Spent Fuel.... 2.5

2.5 Summary Ranking of the Selected TRUW Treatment Options ......... 2.6

4.1 Summary of the Regulations/Criteria Related to TRUW

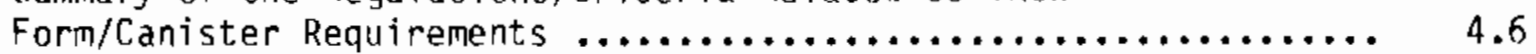

5.1 Containers per Year of Intreated TRUW $\ldots \ldots \ldots \ldots \ldots \ldots \ldots \ldots \ldots \ldots . \ldots . \ldots$

5.2 Annual Volumes of Containers of Intreated TRIJW ............. 5.6

5.3 Unit Volumes of Untreated TRIJW Before Containerization $\ldots \ldots \ldots \ldots .5 .7$

5.4 Unit Weights of Intreated TRIJW Before Containerization ........ 5.9

5.5 Comparison of IIntreated TRIJW Ouantities $\ldots \ldots \ldots \ldots \ldots \ldots \ldots \ldots \ldots \ldots . \ldots \ldots$

5.6 Maximum Possible Variation in Initial Waste nuantities Resulting from Plus or Minus Three-Fold Incertainties in TRU Radionuclide Concentrations

5.1 Applicability of Treatment Method to Waste Types ............. 6.2

7.1 Description of Each Treatment Option by waste Type ........... 7. ?

7.2 Weights, Volumes, and Containers of TRIJ from Option 1 -

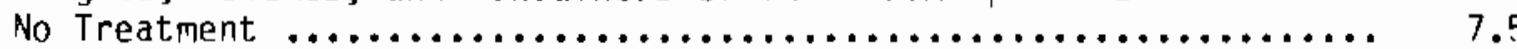

7.3 Weights, Volumes, and Containers of Treated TRIJW from Option 2 Minimum Treatment

7.4 Weights, Volumes and Containers of Treated TRUW from Option 3 Minimum Number of Processes and Products .................. 7.10

7.5 Weights, Volumes and Containers of Treated TRUW for Option 4 Maximum Volume Reduction Without Decontamination 
7.6 Weights, Volumes, and Containers of Treated TRIIW from Suboption 5A - Maximum Volume Reduction with Decontamination ..... 7.16

7.7 Weights, Volumes, and Containers of Treated TRIIW from Suhoption 5R - laximum Volume Reduction with necontamination ..... 7.17

7.8 Weights, Volumes, and Containers of Treated TRlw from nption 6 -

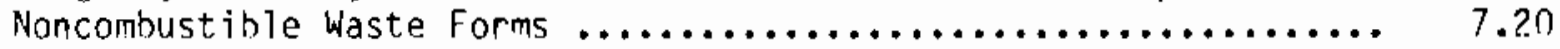

7.9 Initial and Final Volumes of Packaged Waste from Fach

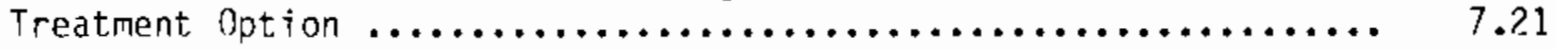

7.10 Number of Canisters/Drums Produced from Each TRIW Treatment

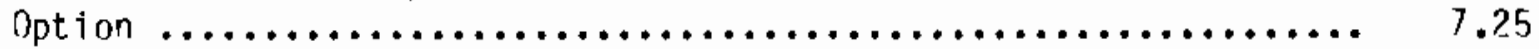

8.1 Amortized Capital Costs for the Six TRIW Treatment Options ...... 8.2

8.2 Operating Costs for the Six TRlw Treatment notions ........... 8.3

8.3 Summary of TRtJW Facility Amortized Capital and Operating Costs for the Six TRlw Treatment Options ................... 8.4

8.4 Transportation Costs for the Six TRIW Treatment Options ........ 9.5

8.5 Disposal Costs for the Six TRllw Treatment Options ........... 8.6

8.6 Total Life-Cycle Cost for llanagement of TRLIW, HLW, and LLW ...... 8.7

9.1 Comparison of Likely Waste Form Characteristics for the Six TRIIW Treatment Options, with Potential Requirements ......... 9..?

9.2 Overal1 Dualitative Comparison of Processing Characteristics for the Six TRIJW Treatment Options ........................ 9.7

9.3 Summary Ranking of the Six TRIJW Treatment Options ............ 9.9 


\subsection{INTRODUCTION}

Transuranic waste (TRIJ) will be generated during the spent fuel reprocessing and fuel refabrication steps of the nuclear fuel cycle, in which fissionable uranium and plutonium are recovered and recycled for beneficial use. Transuranic wastes can also be generated in the handing and storage of spent fuel, particularly if any of the fuel cladding is failed. Defense activities in the processing of plutoniur for weapons have generated TRU wastes as well.

Transuranic waste consists of unusable material contaminated with transuranic radionuclides in concentrations greater than $100 \mathrm{nCi} / \mathrm{g}$ of waste. Transuranic waste can originate in a wide variety of forms. Original commercial TRUW forms can include failed equipment, fuel cladding and hardware, ventilation filters, process solids, and general process and laboratory operational scrap (which includes paper, rags, wood, glass, metals, plastics, and ceramics). (a) The final type of disposal of commercial TRU wastes has not been determined, but it is expected to be deep geologic disposal with commercial HLW. In this case the TRU wastes, plus the other engineered barriers in the repository, may be required to meet the 11.S. Nuclear Regulatory Comission (NRC) requirement for control of the annual fractional release rate of radionuclides to less than $10^{-5}$. It is likely that most of the wastes will need some type of treatment to meet this limit. Tests of the selected products will be needed to confirm their acceptability.

Because of the possible need for a number of treatment processes for the wide variety of original TRIW forms, it is appropriate to study the potential treatment strategies and their impacts on the waste management system. Fuel reprocessing will generate TRUW that includes the full range of original waste forms. These wastes will also have a broad range of beta-gamma radioactivity levels, which will require that significant amounts be shielded and remotely handled. Mixed oxide (MOX) fuel refabrication will generate TRUW with a much

(a) Original TRUW forms can also include organic and inorganic liquids, and process sludges, but these are assumed in this study to be intermediatelevel wastes. 
narrower range of forms and with generally little heta-garma radioactivity content. It was thus helieved that an analysis of potential waste treatment strategies for TRIJW from fuel reprocessing of spent fuel would he hroad enough to cover most of the waste management concerns for hoth fuel cycle steps.

The study documented in this report was performed for the II.S. Department of Energy (DOE) as part of the Nuclear Waste Treatment Program (NWTP) heing conducted by the Pacific Northwest Laboratory ( $\left.P N_{-}\right)$. The study was also conducted in collahoration with related work being carried out for DOE's Office of Civilian Radioactive Waste Management (OCRWM) in the Waste Management Systems Studies at PNL (Mckee et al. 1984). The objectiva of this study is to provide analyses of various TRUW treatment options at a fuel reprocessing plant and the cost impacts of these options on the total waste nanagement system. Six options with differing fundamental objectives were studied. The results of the study will provide DOE with a hasis for decisions concerning the scope, schedule, and budget for the transuranic waste stadies of the NucTear Waste Treatment Program. This study represents the first step in the development of an integrater TRIJW treatment technology (discussed in Section 3).

This report is divided into 10 sections. Section? is a summary of the results and conclusions. Section 3 describes the plans for development of overall TRIJ treatment technology and the approach for this study, and Section 4 provides the overall bases for the study. The characterization of TRIJW streams is given in Section 5. Section 6 presents the definition of the six basic treatment options evaluated, the logic for their derivation, and initial screening. Section 7 presents the detailed process descriptions of the six basic treatment options, and Section 8 presents an evaluation of waste management costs. An overall evaluation and a comparison of results are given in Section 9, and conclusions and recommendations are provided in Section 10. References and supporting appendixes follow.

\subsection{REFERENCE}

Mckee, R. W., L. L. Clark, P. M. naling, J. F. Nesbitt, and J. L. Swanson. 1984. "Fconomic Analys is of Waste Management System Alternatives for Reprocessing Wastes." Waste Management 1984, pp. 383-393. University of Arizona, Tucson. 


\subsection{SUMMARY}

Transuranic waste (TRUW) treatment strategies have been prepared based on the treatment, transportation, and disposal of high-level waste (HLiW) and TRIW from a reference reprocessing plant. The Barnwell Nuclear Fuel Plant (BNFP) was the reference facility selected for this study. The potential waste streams from this facility have been well characterized and reviewed previously (Marr 1983). The streams were grouped into the five categories of hulls and hardware, failed equipment, filters, fluorinator solids, and general process trash (GPT) plus sample and analytical cell (SAC) wastes. These wastes are composed of a wide variety of materials including meta?, cellulose, plastics, and rubber.

Six potential treatment options, including the option of no treatment, were selected for the five categories of waste and are summarized in Table 2.1. These options were selected to represent different ohjectives and potential methods for ohtaining them. Reducing waste volumes was found in all cases to reduce waste management system costs. Several of the options consider different ways to reduce waste volumes (e.g., compaction, incineration, melting, and decontamination). The ability of each of the options to reduce the volume of waste is shown in Table 2.2. The options demonstrate that it is possible to reduce the TRUW volumes by a factor greater than 10, using selected processing methods. Ass shown, Option 5 (decontamination) includes the incorporation of some TRUW into the HLW stream and the removal of TRIJ contamination to convert some TRUW to low-level waste (LLW). Decontamination has the potential to provide the greatest reduction in the volumes of TRliW plus HLW, but it also generates a large volume of $\mathrm{LLW}$.

Since some of the TRUW is converted to $H L W$ in one of the treatment options evaluated (Dption 5), and since the disposal costs for HLW and TRINW in the same deep geologic repository are interdependent, the total costs for hoth HLW and TRUW are considered in this evaluation. Incremental costs for LLW resulting from TRUW treatments are also included.

The calculated costs for treatment, transportation, and disposal of the treated TRUW (and incremental LLIV) from reprocessing 70 , n0ก $14 T U$ of spent fuel 
TABLE 2.1. Summary of the Six TRIJW Treatment Options(a)

\begin{tabular}{|c|c|c|}
\hline Option & Title & Ohjective \\
\hline 1 & No treatment & No treatment of wastes \\
\hline 2 & Minimum treatment & $\begin{array}{l}\text { Reduce volume with } \\
\text { simple technology }\end{array}$ \\
\hline 3 & $\begin{array}{l}\text { Minimum number of } \\
\text { processes and } \\
\text { products }\end{array}$ & $\begin{array}{l}\text { Treat wastes in similar } \\
\text { manner to produce one type } \\
\text { of simple waste form }\end{array}$ \\
\hline 4 & $\begin{array}{l}\text { Maximum volume } \\
\text { reduction without } \\
\text { decontamination }\end{array}$ & $\begin{array}{l}\text { Treat wastes to produce } \\
\text { minimum final waste volumes }\end{array}$ \\
\hline 5 & $\begin{array}{l}\text { Maximum volume } \\
\text { reduct ion with } \\
\text { decontamination }\end{array}$ & $\begin{array}{l}\text { Decontaminate TRIJW } \\
\text { to produce LLW }\end{array}$ \\
\hline 6 & $\begin{array}{l}\text { Noncombustible } \\
\text { waste forms }\end{array}$ & $\begin{array}{l}\text { Reduce volume and } \\
\text { eliminate combustibles }\end{array}$ \\
\hline
\end{tabular}

Primary Treatments
Assay to certify TRU content
and whether contact or remote
handled

A1l wastes are mechanically compacted to reduce volume

All wastes are mixed with cement or grouted

Metals are melted, cellulose combustibles are incinerated, rubber and plastics are hot pressed, and residues are melted

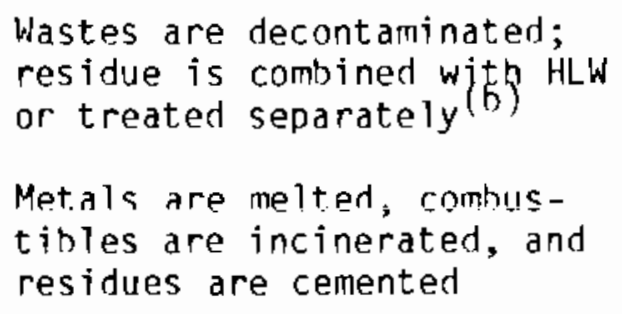

Wastes are decontaminated; residue is combined with $\mathrm{HLW}$ or treated separately $(b)$

Met.als are melted, combustibles are incinerated, and residues are cemented

(a) HLW is treated by vitrification in all options. A more detailed description of TRUW treatments is given in Table 7.1.

(b) Suboption 5A vitrifies decontamination solutions with HLW glass, while Suboption 5B dries the decontamination solution and hot presses the solids from hull treatment. 
TARLE 2.?. Annual Volumes of Treated Wastes from a 1,5n0 MTU/yr Reprocessing Plant for the Six TRUW Treatment Options

\begin{tabular}{|c|c|c|c|c|c|}
\hline \multirow[b]{2}{*}{ Option } & \multirow[b]{2}{*}{$\begin{array}{c}\text { Contact-Handled } \\
\text { TRIW, } \mathrm{m}^{3} \\
\end{array}$} & \multicolumn{3}{|c|}{ Increase in } & \multirow[b]{2}{*}{$\begin{array}{r}\text { Total TRUW } \\
\text { and HLW, } \mathrm{m}^{3} \\
\end{array}$} \\
\hline & & $\begin{array}{c}\text { Remote-Handiled } \\
\text { FRUW, } \mathrm{m}^{3} \\
\end{array}$ & $\begin{array}{c}\mathrm{HLW}, \\
\mathrm{m}^{3} \\
\end{array}$ & $\begin{array}{l}\operatorname{LLW}, \\
\mathrm{m}^{3} \\
\end{array}$ & \\
\hline 1 & 480 & 980 & -- & - & $1,46 n$ \\
\hline 2 & 55 & $3 n 0$ & -- & -- & 355 \\
\hline 3 & 89 & 860 & - & -- & 949 \\
\hline 4 & 7 & 110 & -- & -- & 117 \\
\hline $5 A$ & 4 & 14 & 79 & 530 & 97 \\
\hline $5 B$ & 4 & 23 & 4 & 530 & 31 \\
\hline 6 & 28 & 110 & -- & 57 & 138 \\
\hline
\end{tabular}

are shown in Table 2.3. All other treatment options have costs lower than those for Option 1 (no treatment), and these incrementally lower costs range from $\$ 0 . ?$ billion for Option 3 (minimum number of processes and products) to $\$ 2.0$ billion for 0ption 6 (noncombustible waste forms). The increase in treatment costs for Options ? through 6 over those for Option 1 are more than compensated for by significant reductions in transportation and disposal costs. It should he added that the largest contribution to disposal costs in Suhoptions $5 \mathrm{~A}$ and 59 (maximum volume reduction with decontamination) comes from incremental LLW disposal costs.

Table 2.4 includes the same costs given in Table 2.3, with the addition of HLW management costs. These costs show the total costs for the system defined in this study. (Treatment R\&D and decommissioning costs and repository selection and development costs are excluded in this study.) Again, all the other treatment options have a lower overall cost than nption 1 (no treatment). A significant reduction in transportation and disposal costs can be noted by comparing the costs for Options 2 through 6 with the costs for Option 1 . These cost differences demonstrate the major impact of volume reduction on overal? system costs.

Comparison of Tables 2.3 and 2.4 shows various reductions in the cost incentives for the treatment options (Option ? through 6) when incremental HLW 
TABLE 2.3. Costs for Treatment, Transportation, and nisposal of TRIIW and Incremental LLW from 70,000 MTU of Reprocessed Spent Fuel (undiscounted $1983 \$$ billions) (a)

Cost Reduction

Relative.

\begin{tabular}{|c|c|c|c|c|c|}
\hline nption & Treatment & Transportation & Disposal & Total & to Option 1 \\
\hline 1 & 1.2 & 1.4 & $2 . ?$ & 4.8 & - \\
\hline 2 & 1.5 & 0.3 & 1.4 & 3.2 & 1.6 \\
\hline 3 & 1.5 & 1.? & 1.9 & 4.6 & $n .2$ \\
\hline 4 & 2.2 & 0.1 & 0.6 & 2.9 & 1.9 \\
\hline $5 A^{(b)}$ & 2.6 & 0.05 & 0.7 & 3.4 & 1.4 \\
\hline${ }_{5 B}(b)$ & 3.0 & 0.06 & 0.7 & 3.8 & 1.0 \\
\hline $6^{(b)}$ & 2.2 & 0.1 & 0.6 & 2.9 & 2.0 \\
\hline
\end{tabular}

(a) Treatment costs include amortized capital and operating costs; transportation costs assume commercial general freight costs plus cask leasing plus security costs; disposal costs include construction and operation costs of a hasalt repository for TRUW and HLW, and commercial burial ground charges for LLW disposal.

(b) Includes incremental costs for LLW treatment, transportation, and disposal, which are incurred in this option.

management costs are added to derive the system costs. However, these system cost reductions are still significant in some cases (0ptions ?, 4, and 6), ranging from $\$ 0.1$ billion in Option 3 (minimum number of processes and products) to $\$ 1.7$ hillion in 0ption 6 (noncombustible waste forms). Option 2 (minimum treatment) has a cost incentive of $\$ 1.5$ hillion and Option 4 (maximum volume reduction without decontamination) has a cost incentive of $\$ 1.6 \mathrm{hillion}$.

The strategy analysis in this study also took into consideration the requirements for waste forms and canisters and waste processing characteristics. The waste form considerations included recognition that the requirements being developed include those for defense TRIW to he sent to the waste Isolation Pilot Piant (WIPP), the Class C LLW requirements in 10 CFR 61 (U.S. NRC 1984a), and the HLW and TRlJW requirements in 10 C.FR 60 (U.S. NRC 1984b) for geologic disposal. Since the detailed disposal method for TRUw has not yet been estabiished and detailed characterization data for the respective waste 
TABLE 2.4. Costs for Treatment, Transportation, and Disposal

of HLW, TRUW, and Incremental LLW from 70,000 "1TII

of Reprocessed Spent Fuel (undiscounted

$1983 \$$ billions) (a)

\begin{tabular}{|c|c|c|c|c|c|}
\hline Opt i on & Treatment & Transportation & Disposal & Total & $\begin{array}{l}\text { Cost Reduction } \\
\text { Relative } \\
\text { to Option } 1 \\
\end{array}$ \\
\hline 1 & 3.7 & 1.7 & 4.9 & 10.3 & -- \\
\hline 2 & 4.0 & 0.6 & 4.2 & 8.8 & 1.5 \\
\hline 3 & 4.0 & 1.5 & 4.6 & 10.2 & 0.1 \\
\hline 4 & 4.7 & 0.4 & 3.5 & 8.7 & 1.6 \\
\hline $5 A^{(b)}$ & 5.5 & 0.6 & 3.9 & 10.0 & 0.3 \\
\hline${ }_{5 B^{(b)}}(b)$ & 5.5 & 0.4 & 3.9 & 9.8 & 0.5 \\
\hline$\sigma^{(b)}$ & 4.7 & 0.4 & 3.6 & 8.6 & 1.7 \\
\hline
\end{tabular}

(a) Treatment costs include amortized capital and operating costs; transportation costs assume commercial general freight costs plus cask leasing plus security costs; disposal costs include construction and operation of a hasalt repository for TRllw and HLW, and commercial hurial ground charges for LLW disposal.

(h) Includes incrementa $\}$ costs for LLW treatment, transportation, and disposal, which are incurred in this option.

forms have not heen obtained, the acceptability of waste forms cannot be fully judged. However, it seems likely that waste forms will be required to provide some immobilization of particulates, high chemical durability, and elimination of any pyrophoric and combustible materials. In comparing the probable waste form characteristics in the treatment options with these potential requirements, Option 6 was judger to be the most likely to be acceptable under the anticipated requirements. Options 3, 4, and 5 were considered likely to be generally acceptahle. However, there are concerns about the particulate, potentially pyrophoric, and combustible materials present in Options 1 and ?. The relative ranking of the process options relative to waste form requirements is given in column 3 of Table ?.5.

Processing characteristics such as operational safety, process complexity, technology status, and process flexibility were evaluated qualitatively by the 
authors. The aggregate results are shown in column 4 of Table 2.5. The simpler treatment options (Options 1 and 2) possess the more favorable processing characteristics. Options 4 and 5 were judged to have the least favorable processing characteristics of the six options, and 0ptions 3 and 6 were judged to be intermediate.

By combining the rankings of the options studied relative to waste form characteristics and processing characteristics with those for system economics (given in Column? of Table 2.5 and hased on the costs in Table 2.4), an approximate overall ranking is given in Column 5 of Table ?.5. This overall ranking, obtained by addition of the values in Columns ?, 3, and 4, assumes that the values are equally weighted. It should he noted that processing would have to he given greater weight than the combined categories of system economics and waste form characteristics to change the results.

This simple comparison provides some valuable insights. The ranking indicates that Option 6 is the most favorable and Options 1 and 5 are the least favorable. Although waste form requirements may not he known currently, they may well provide "go/no-go" hases for evaluating the waste forms for the

TABLE 2.5. Summary Ranking of the Selected TRUW Treatment Options

\begin{tabular}{|c|c|c|c|c|}
\hline Option & $\begin{array}{r}\text { System } \\
\text { Economics }\end{array}$ & $\begin{array}{c}\text { Waste Form } \\
\text { Characteristics (a) }\end{array}$ & $\begin{array}{c}\text { Processing }(a) \\
\text { Characteristics }\end{array}$ & $\begin{array}{c}\text { Approximate } \\
\text { Overall } \\
\text { Ranking }\end{array}$ \\
\hline 1 & 6 & 6 & 1 & 13 \\
\hline 2 & 3 & 5 & $?$ & 10 \\
\hline 3 & 5 & 4 & 3 & $1 ?$ \\
\hline 4 & 2 & 2 & 5 & 9 \\
\hline 5 & 4 & 3 & 6 & 13 \\
\hline 6 & 1 & 1 & 4 & 6 \\
\hline
\end{tabular}

(a) Ranking of from 1 (most favorable) to 6 (least favorable of the group).

(h) Approximate overall ranking is hy addition of the prior three values for each option, with the lower numbers heing the most favorable. 
various strategies. In that case, the options with the poorer waste form ranking (higher numbers) could well be eliminated, and the hetter waste forms would have a better chance of meeting the requirements. The more extensive treatment options (Options 4, 5, and 6) are ranked the most desirable in the waste form category, with the ranking for Option 6 as the most favorable. Option 6 also presents the most favorable system economics and has the most favorable processing characteristics of the more extensive treatment options (0ptions 4 , 5 , and 6). Option 5 appears to he the least favorable of the more extensive treatment options.

Rased on these evaluations, it appears that Option 6 potentially may have the most favorable characteristics of all the options studied. Option 4 appears to have the next most favorable characteristics of the more extensive treatment options, and ranks least favorahly only in processing characteristics.

Implementation of Options 1,?, and 3 would require little or no R\&n, but these options rank relatively poorly. Option 6 appears to offer significant potential advantages over the other options, and Ren for this option appears to be warranted. Next in 1 ine for potential improvements in the waste management system is option 4 .

nther options could be constructed for further evaluation based on the selection and evaluation of specific treatments from the six options presented here. For example, a simplified decontamination option that would decontaminate the hulls and leave the remaining wastes to he treated by other methods could be examined. Hulls are of special interest hecause they are the largest volume stream and have high radiation levels.

In constructing the treatment options evaluated in this study, it was recognized that high-efficiency particulate air (HEPA) filters comprise a relatively large volume of waste that is apparently difficult to treat. It should also be recognized that the treatment of polyvinyl chloride (PVC) plastics presents process difficulties, and that the development or utilization of alternative materials (to eliminate PVC, and halogen-containing materials from TRUW) would simplify TRIJW incineration. 
This study demonstrated that there are significant opportunities for combining wastes for treatment. Therefore, future Rin should consider all the waste streams, as we have done in this study. Metal melting, incineration of combustibles, and cementing of residues are cantidates for further development based on the six basic options studied. These processes have the capabilities to reduce waste volume and waste management system costs, to handle a large variety of wastes, and to produce good quality waste forms.

\subsection{REFERENCES}

Darr, D. G. 1983. Waste Model Characteristics Study: Evaluation of Reprocessing Waste Estimates. D0E/3156/FR-01, ATlied-Gieneral Nuclear Services, Barnwell, South Carolina.

U.S. Nuclear Regulatory Commission. 1984a. Code of Federal Regulations, Title 10, Energy; Part 61, Licensing Requirements for Land Disposal of Radioactive Waste, Final Rule. IJ.S. Federal Register, V01. 47, December 27, 1982 (Effective January 26, 1983), p. 57463. 1f.5. NRC, washington, D.C.

11.S. Nuclear Regulatory Commission. 1984b. Code of Federal Regulations, Title 10, Energy; Part 60, Disposal of High-Level Radioactive Wastes in Geologic Repositories (Subpart E, Technical Criteria). Final Rule, II.S. Federal Register, Vol. 4R, No. 120, June ?.1, 1983, pp. 28194-28?29. I.5. NRC, Washington, D.C. 


\subsection{STUDY APPROACH}

This study represents the first step in the development of an integrated TRUW treatment technology, as illustrated in Figure 3.1. Following this strategy analysis are three activities: 1) more detailed selection of processes

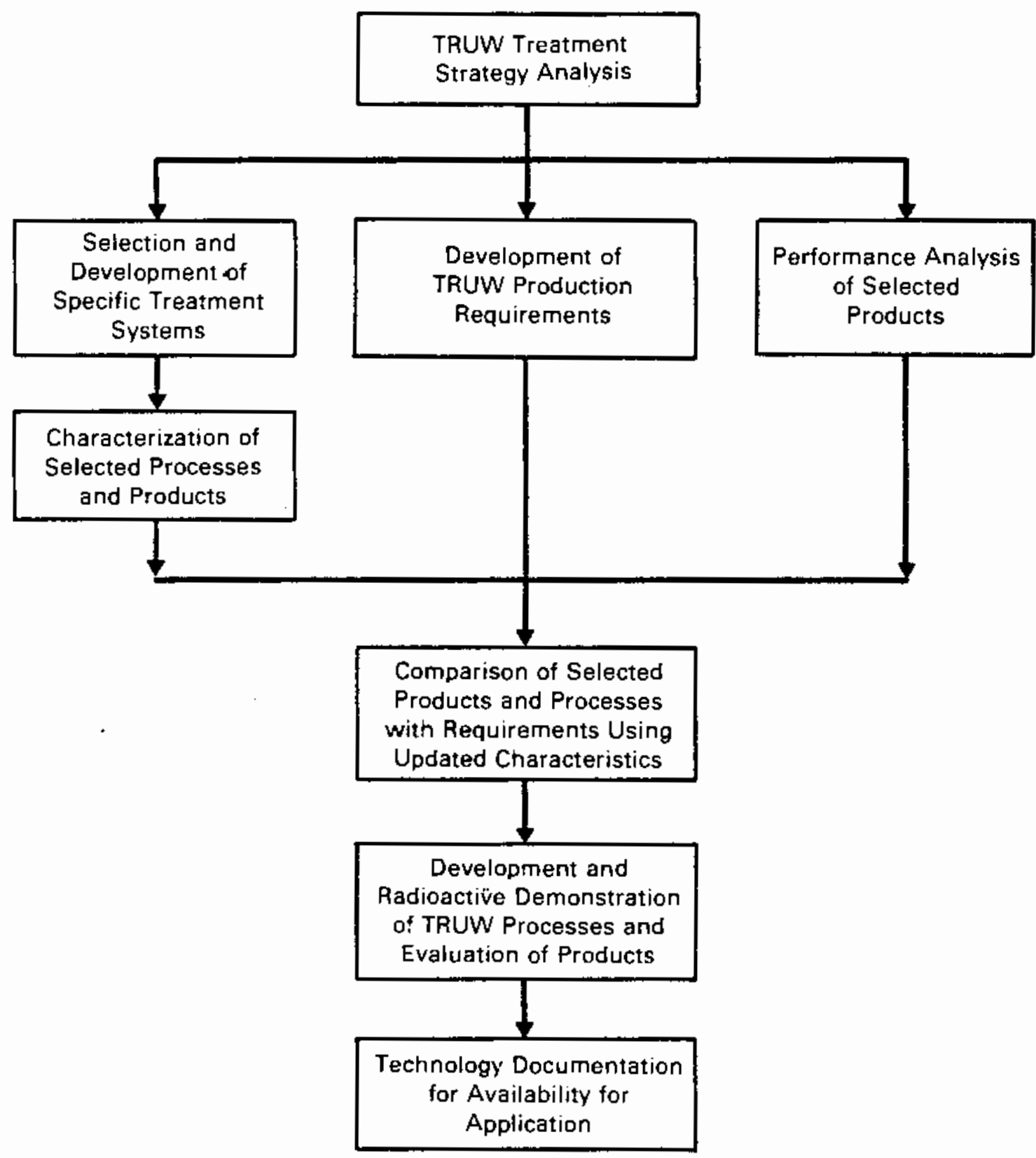

FIGURE 3.1. Major Steps in TRIWW Treatment Development Program 
(e.g., what type of incinerator?) and their development, if needed; 2) development of TRU waste production requirements (i.e., citeria) with concurrence from the repository program staff to ensure that the products will be compatible with the repository systems (e.g,. the limits on size and weight of the containers); and 3) completion of a performance assessment of the selected products in repository environments. After the processes are selected and actual products made, characterization of the selected processes and products can be accomplished. With actual product data, production requirements, and performance analyses completed, a final determination can be mate on the appropriateness of the conclusions reached in this document. With confirmation of the conclusions, major development and demonstration activities can be completed to provide the technology to future users with a fulty documented technology.

The approach used in this study is illustrated in Figure 3.2. The first step was to identify the study hases, described in Section 4 . Data from the Barnwell Nuclear Fuel Plant (BNFP) were used as the primary source for waste type and waste volume information (Marr 1983). Minor modifications in the primary data were made hased on data in the literature and the experience of the authors. Waste volumes and waste descriptions are covered in Section 5 . The possible treatment options for each type of waste were then considered, as described in Section 6 . Six objectives were established for selecting treatment processes: no treatment (Option 1), minimum treatment (Option 2), treatment by one immohilization process (0ption 3), maximum volume reduction (0ption 4), maximum use of decontamination (Option 5), and preparation of waste forms without combustibles (0ption 6).

These objectives were then used to select treatment options. This selection resulted from numerous meetings of the authors in which the effects of various processing combinations were considered; the results of these discussions are described in Section 6. After the selection of the options to be evaluated, the volume of wastes that would he shipped for disposal to the repository or to a LLW facility was determined for each option. Using these volumes, the costs of transportation and disposal were determined and treatment costs were estimated and are included in Section 8 . Considerations other than costs are addressed in Section 9. With these data, general recommendations 


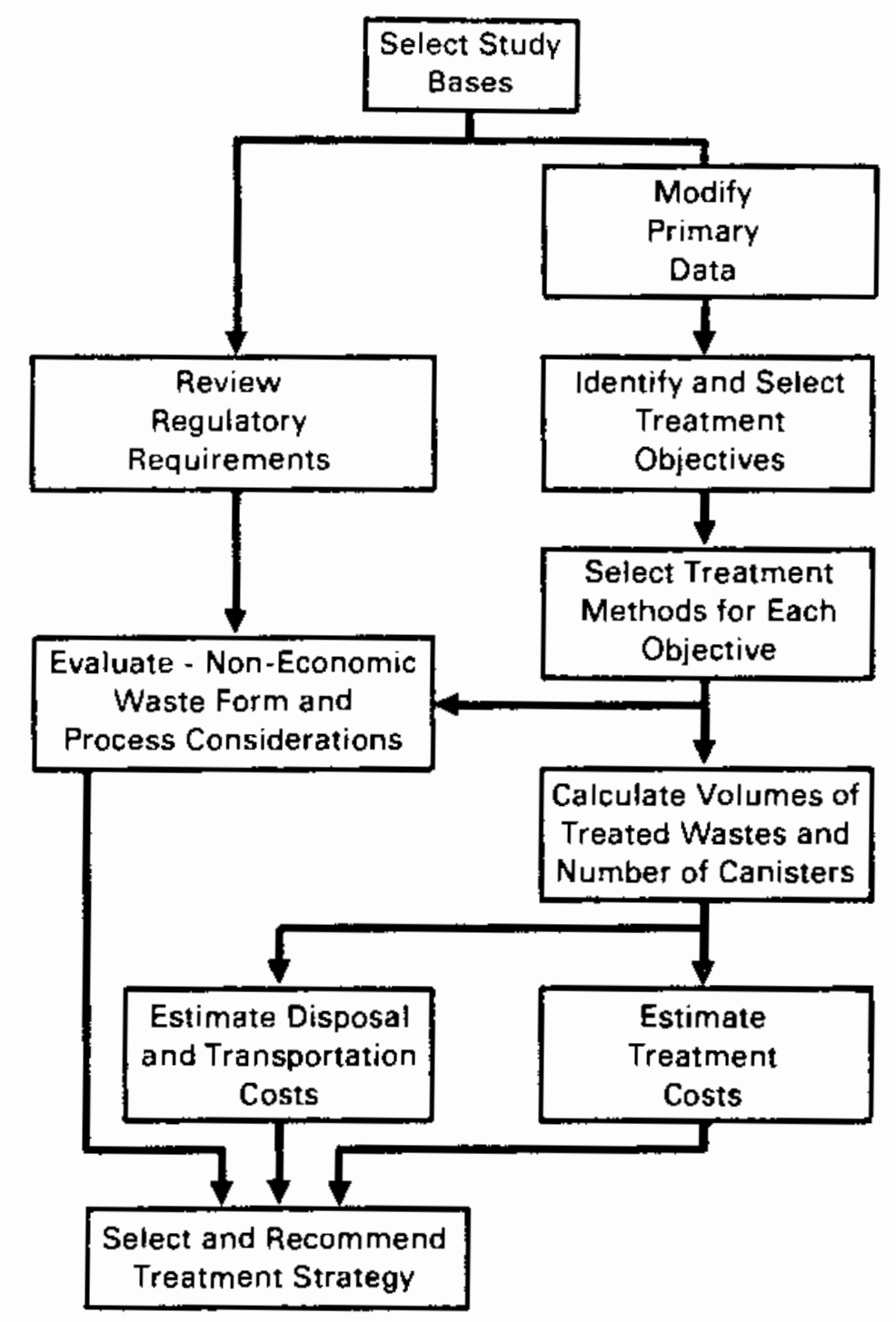

\section{FIGURE 3.2 Flow Chart for Strategy Evaluation}

were selected for the treatment strategy discussed in Section 9. Finally, the resulting recommendations for further treatment technology considerations and for the selected treatment options are provided in Section 10.

\subsection{REFERENCE}

Darr, D. G. 1983. Waste Model Characteristics Study: Evaluation of Reprocessing Waste Estimates. DOE/3156/FR-01, Allied-General Nuclear Services, Barnwel1, South Carolina. 
- 


\subsection{OVERALL BASES FOR STUDY}

This section identifies the major technical hases and assumptions used in the study, including regulatory hases. The bases are applied to the overall study approach described in Section 3 and are used for developing the detailed data and analyses in the subsequent sections.

\subsection{TECHNICAL BASES AND ASSUMPTIONS}

The major technical hases and assumptions used in the study are given below.

- The BNFP is the reference reprocessing plant for this study. The BNFP includes 1) a fuel receiving and storage station, ?) a separations facility, 3) a plutonium dioxide conversion facility, 4) a waste processing facility, 5) waste storage, and 6) a physically separate uranium hexafluoride conversion facility. Although there are no commercial reprocessing plants currently operating in the U.S., the construction of the RNFP was nearly complete when it was discontinued, and the plant is helieved to he reasonably representative of the state-of-the-art design of commercial-scale fuel reprocessing plants. In addition, the BNFP staff performed waste management studies specific to that plant for noE from 1979 to 1983 (Anderson et al. 1979, Anderson and Fvans 1983, Boone and Ehel 1983, Darr 1983); these reports provided useful information for this study. This study aiso used information from a related ongoing study on Waste Management Systems Analyses for DOE's Office of Civilian Radioactive Waste Management (OCRWM).

- A11 TRUW treatment is assumed to he at the reprocessing plant, not at a central treatment, storage, or repository facility.

- High-level liquid waste (HLLW) and raffinates from downstream solvent extraction cycles are combined in the normal plant flowsheet and are converted to a borosilicate glass as HLW. Thus HLW is excluded from this study, except in the cases where some of the TRIJ is combined 
with HLW. In these cases, the incrementa? impacts of the TRIIW addition to HLW are identified and evaluated.

- Existing information is used for characterizing the TRUW from the reference reprocessing plant. Most of the information used is taken from the Darr (1983) study and from DOE/ET-IIN28 (U.S. DOE 1979); these sources are helieved to be the most comprehensive analyses related to the needs of this study. Appropriate adjustments have been made here to some of the information from these sources.

- All waste streams in the reference fuel reprocessing plant that could potentially he designated as TRIJW are considered in this study. However, all streams that are indicated hy Darr (1983) to be non-TRuw are excluded as TRIN here. This assumes that an efficient assay system is in place in the facility to discriminate accurately between waste streams that are TRIM and those that could he, but are not, TRIIW. Some sensitivity analyses were conducted to determine whether factors of \pm 3 in TRIJ nuclide concentrations in waste streams would change the classification of the wastes.

- The definition of TRIJ used here is from the fourth working draft of the proposed regulation 40 CFR 191 (11.S. F.PA 1984a): "'Transuranic wastes', as used in this Part, means wastes containing more than 100 nanocuries of alpha-emitting transuranic isotopes, with half-lives greater than twenty years, per gram of waste." Corrections are applied, as described in 10 CFR 60 (1I.S. NRC 1984a) and 10 CFR 61 (1I.S. NRC 1984h), for the allowable amount of beta-emitting ${ }^{241} \mathrm{Pu}$ (a factor of 35 is applied to allow for alpha recay of its daughters), and for short-1ived alpha-emitting ${ }^{242} \mathrm{Cm}$ (a factor of 200 is applied to allow for alpha decay of its long-lived daughters). Additional definitions of TRUW are discussed in Appendix $C$.

- Transuranic waste is assumed to be disposed of in a deep geologic repository concurrently with HLW. The impacts of various TRIJW strategies on waste disposal would thus be incremental to the disposal of other wastes resulting from spert fuel recycling. Some of the disposal requirements for TRUW are identified in the 
regulations, if it is emplaced in a deep geologic repository. Since TRIW is excluded from shallow-land hurial, the use of deep geologic disposal appears to he a reasonable assumption for this study.

- Detailed waste form requirements at a repository are currently unknown. The treatments studied inclide a broad range of waste form characteristics.

- Processing concepts within the reference reprocessing plant for the various treatment systems are hased primarily on work hy former RNFP staff, with modifications made by the authors of this study to ensure consistency.

- Costs of the treatment processes within the reference reprocessing plant are hased primarily on those provided by Mckee et a7. (1984), with modifications made for differences in hases. Research and development and decommissioning needs and their costs are not evaluated. Costs are based on undiscounted 1983 dollars.

- Oniy one reference transportation system is defined and used for TRUW. The system assumed is that used in the Mckee et al. (1984) study. Transportation costs are based on information from the same source as the Mckee report.

- The reference repository is located in basalt, using the RWIP design (Kaiser Engineers Inc./Parsons, Rrinkerhoff, Duade, and Douglas, Inc. 1983). Disposal costs are determined using the Repository F.conomics (RECON) model (Clark et al. 1983).

- Costs for LLW disposal are hased upon the cost schedule of ChemNuclear Systems dated January 1, 1984 (Chem-Nuclear Systers, Inc. 1984).

- Reprocessed fuel is assumed to have received an average integrated exposure of 28,500 megawatt rays per metric ton heavy metal (MWD/ MTU). Wastes are assumed to be from spent fuel that is 9 years outof-react or (Darr 1983). 
- No extended interim onsite storage of TRIW is considered in this study, except for lag storage needed before and after processing. The impacts of various onsite lag storage strategies would require a separate evaluation.

\subsection{REGIILATORY BACKGROINN}

The final treated waste form and its canister will have to meet federal regulations for interim storage, transportation, and ultimate disposal. This section sumarizes the major regulations concerning TRUW management with respect to their potential impact on the selection of TRIJW treatment strategies and subsequent waste management steps. Additional details are given in Appendix C.

\subsubsection{Generally Applicable Regulations}

The basic federal regulation for environmental radiation protection for the operation of uranium nuclear fuel cycle facilities is stated in 40 CFR 190 (U.S. EPA 1984a). This regulation applies to the waste management steps of waste generation, treatment and storage, and the filling and presealing of waste disposal repositories. It does not, however, apply to disposal. The basic federal regulation for radioactive waste disposal is stated in draft 40 CFR 191 (1).S. EPA 1984b, 1985); however, the part of this regulation dealing specifically with waste form/repository performance requirements has not been finalized.

The basic NRC regulation, "Standards for Protection Against Radiation," is stated in 10 C.FR 20 (1I.S. NRC 1983C). This regulation gives some dose limits and references 40 CFR 190 . The 10 CFR 20 regulation also states that anticipated doses should be reduced to as low as reasonably achievable (ALARA).

The basic regulations regarding radiation protection of the public during transportation of radioactive materials are also covered in 10 CFR 20 . Specific regulations have been issued by the U.S. Department of Transportation (DOT) in 49 CFR 171-178 (1).S. DOT 1984) and by the NRC in 10 CFR 71 (1).S NRC 1984d). These latter two regulations specify packaging requirements, radiation limits, labeling requirements, handling procedures, and security procedures. 
The principal performance requirement for transportation of TRIJ concerns containment, which is generaliy provided by the outer transportation packaging [i.e., the cask for remotely handled TRUW (RH TRIW), or the Transuranic Package Transporter (TRUPACT) packaging for contact-handled TRUW (CH TRUW)].

\subsubsection{Regulations Relating to Release Rates from Repositories (i.e.. regulations that may be related to waste forms)}

Detailed regulations and requirements for commercial TRIJ forms are not currently available. However, regulations have been developed for HLW (10 CFR 60) and LLW (10 CFR 61) by NRC, and have been proposed for waste disposal by EPA (40 CFR 191). The Nuclear Waste Policy Act of 1982 (NWPA) provides direction for the disposal of $\mathrm{HLW}$ and spent fuel but does not specifically address TRUW. However, TRUW could be interpreted as HLW in the NWPA by the following definition of HLW: "other highly radioactive material that the Commission, consistent with existing law, determines by rule requires permanent isolation." Detailed requirements and specifications have been prepared for defense TRUW to be sent to the Waste Isolation Pilot Plant (WIPP) (Westinghouse 1984).

In anticipating requirements for commercial TRUW, a range of possibilities has been considered. The minimum requirements would likely be those which are applied to wastes going to the WIPP and/or those for commercial LLW Class C. The maximum requirements would be those applied to commercial HLW, if TRUW is to be disposed of in a commercial geologic repository. It is the purpose of this section to identify all of the potential requirements which could be applicable to TRUW forms and canisters. Table 4.1 has been constructed to provide a perspective of the potential disposal requirements for TRUW. It is recognized that some of the requirenents (e.g., those that are concerned with subsidence on the LLW site) may not be applicable to deep geologic repository disposal. We have therefore not selected strategies for evaluation based solely on their ability to meet the most stringent requirements. A discussion of the waste form needs as they relate to release rates from repositories is provided in the following subsections. 


\section{TABLE 4.1. Summary of the Regulations/Criteria Related to TRIW Form/Canister Requi rements $(a)$}

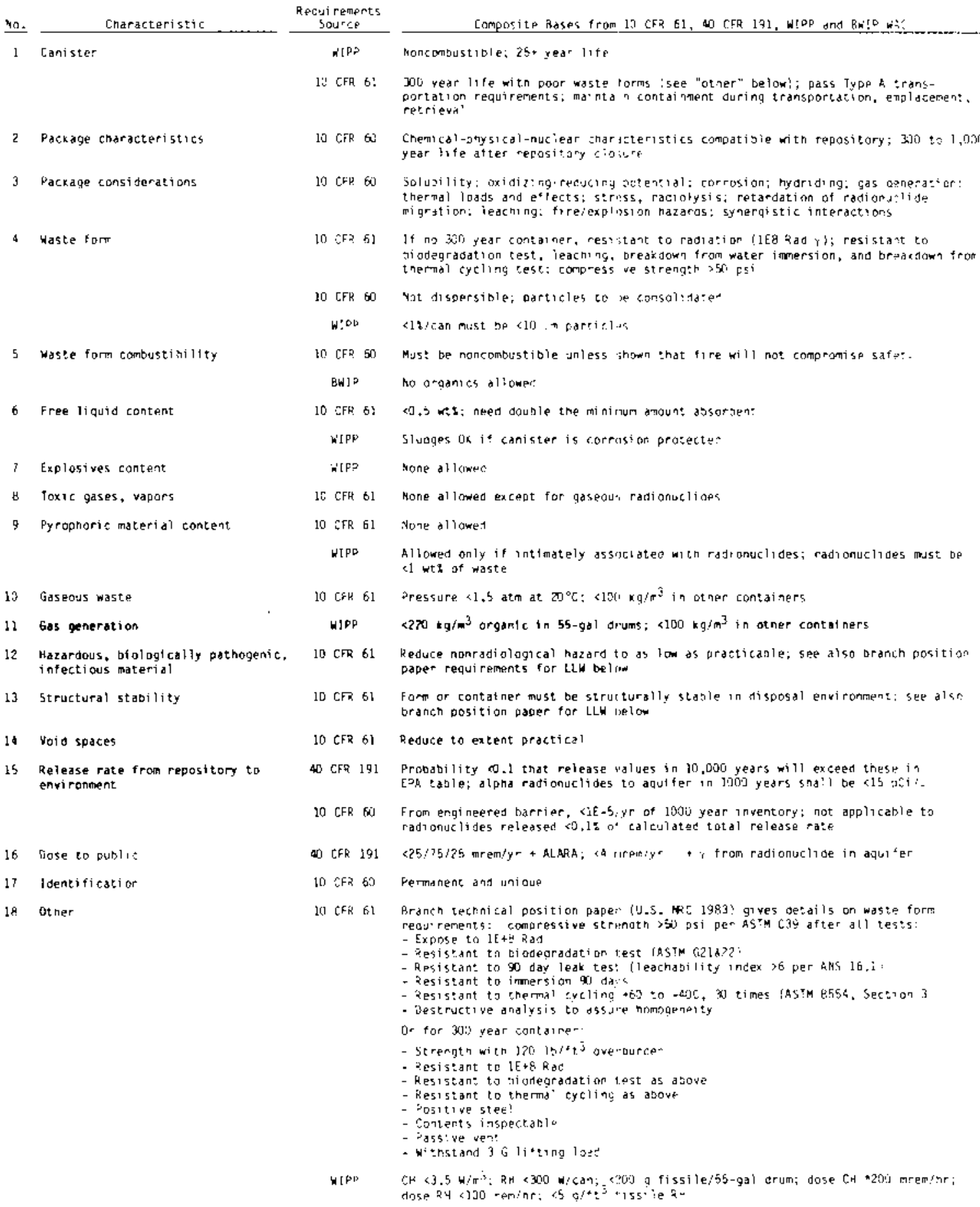

(2) See Table c.l for more tnformatior. 


\subsubsection{EPA Requirement for TRUW}

The fifth working draft of 40 CFR 191 specifies the minimum concentrations of radionuclides in radioactive waste required to classify it as HLW. These values are identical to the maximum limits for wastes acceptable for shallow land burial, provided in 10 CFR 61 , and also include some radionuclides not specifically identified in 10 CFR 61. It should be noted, however, that the fourth working draft of 40 CFR 191 deletes the table that gives numerical concentrations for classifying HLW.

The EPA requirements for disposal of TRUW and $H L W$ do not directly state waste form or canister requirements; instead, they specify the limits of amounts of TRUW constituents that can be released per 1 million curies of TRU nuclides present in TRUW to the accessible environment over a period of 10,000 years. From calculations in this study, 1 million curies of TRU nuclides in TRIJW result from reprocessing 84,000 MT of the reference spent fuel, and TRUW from reprocessing plants contains about $0.225 \%$ of the TRU nuclides present in the original spent fuel. Based on information in DOE/ET-0028, Volume 1 , the TRU nuclides in TRUW from MOX fuel refabrication plants are about $0.12 \%$ of the TRU nuclides present in spent fuel. By including the amount of TRU nuclides in TRUW from both fuel reprocessing and MOX fuel reprocessing, 1 million curies of TRU nuclides in TRUW will result from 55,000 MT of original spent fuel. Note that the amount of TRU nuclides in spent fuel is about $1 / 0.00345$, or 290 times that in the equivalent amount of TRUW produced from reprocessing of spent fuel. However, the EPA-proposed regulations recognize a factor of only 55 . Thus the proposed 40 CFR 191 is a factor of about 290/55, or 5.3 times more conservative for allowable release rates from equivalent amounts of TRU nuclides in TRUw compared with those in spent fuel. (See Item 15 in Table 4.1.) This factor of 55 for the performance requirements of TRUW forms in a repository is lower than the factor for spent fuel and only applies to the waste form portion of the series of barriers that retard releases of waste constituents from a repository.

The same kind of reasoning can be applied to the fission and activation products in TRUW. The total fraction of fission products in TRIIW from fuel reprocessing (there are essentially no fission products in TRUW from 10X fuel 
refabrication plants) is about $0.71 \%$ of the amourit in spent fuel (based on Darr 1993). Thus the performance requirement for the waste form plus canister and for other barriers could be reduced by a factor of about 140 for the fission products in TRIlw.

Essentially all of the activation products in irradiated fuel eventually are in the TRIJW (fuel cladding and hardware); these activation products comprise about 1.5 times the number of curies of fission products present in TRlow. Carbon-14 is the only activation product that appears in EPA's list of specific isotopes of concern; thus all other activation products can be put into EPA's category of all other non-TRI nuclides. The EPA's limit for releases of these other non-TRI nuclides is the same as for the fission products ${ }^{135} \mathrm{Cs},{ }^{137} \mathrm{Cs}$, ${ }^{90} \mathrm{Sr}$, and ${ }^{126} \mathrm{Sn}$. Thus the performance requirement for the waste form plus canister for the activation products could be reasoned to be higher by a factor of about 1.5 than those for fission products in TRIJw. Application of this factor of 1.5 to the inverted factor of 140 derived in the previous paragraph implies that the performance requirement for the waste form plus canister for the activation products in TRUW is a factor of ahout 140/1.5, or 93 times lower than that for fission products in spent fuel. For ${ }^{14} \mathrm{C}$, there are about 0.74 and $0.11 \mathrm{Ci} / M T$ of spent fuel in the fuel itself and in the fuel cladding hulls (TRIJ), respectively, for a total of about $850 \mathrm{Ci} / 1,000 \mathrm{MT}$ of spent fuel. The allowable release rate of $100 \mathrm{Ci} / 1,000 \mathrm{MT}$ in the proposed 40 CFR 191 would allow about $12 \%$ of the ${ }^{14} \mathrm{C}$ to be released to the accessible environment from the waste form and canister and from the repository and geologic barriers.

\subsubsection{NRC Requirements for TRUW}

The NRC has not developed regulations specific to TRUW form or disposal requirements, hut their regulations relating to $H L W$ in 10 CFR 60 are stated to be applicable to all radioactive wastes that are disposed of in a geologic repository. It is further emphasized in the discussion of the bases for the NRC requlations that release requirements for radionuclides in TRIJ that are disposed of in a geologic repository are the same as those for high-level waste.

Regulation 10 CFR 60 states that containment. within the waste packages will be substantially complete for a period of at least 300 but no more than 
1,000 years after closure of a repository. In addition, the release rate from the engineered barrier system (which includes any canister overpack, backfill materials, and the entire underground facility) shall not exceed 1 part in 100,000 per year of the inventory of each radionuclide calculated to be present at 1,000 years following permanent closure. (This limit does not apply to any radionuclide that is released from the engineered barrier at a rate of less than $0.1 \%$ of the calculated total release rate limit.)

\subsubsection{Requirements Regarding Release Rates from Waste Forms}

Fractional release rate requirements directly from the waste forms cannot be obtained directly from the existing NRC or the proposed EPA regulations. This is because the EPA regulations specify maximum releases to the accessible environment, and the NRC regulations specify maximum releases from the engineered barrier system in the repository. Thus, allowable release rates are related to the combined performance of a number of barriers and may not necessarily be di rectly related to waste form durability. However, by extrapolating from currently proposed EPA regulations, it can be concluded that, for the equivalent amount of spent fuel, allowable fractional release rates to the accessible enviroment from TRIJ are as follows: for TRL nuclides, about 50 times higher than those from spent fuel; for fission products, about 140 times higher than those from spent fuel; and for activation products, about 90 times higher than those from spent fuel. The NRC release rate limit from the engineered barrier system of 1 part in $100,000 / y r$ may be taken to be applicable to TRU nuclides in TRUW in a deep geologic repository.

\subsubsection{Repository Waste Acceptance Requirements}

High-level waste acceptance requirements for the Basalt Waste Isolation Project (BWIP) have been drafted and provide some additional indications on requirements for the waste going to the repository. Specifically, BWIP, in its concern for the potential of organic complexes forming in the repository and enhancing the migration of actinides, has included in its requirements the following: "The waste form and the internal volume of the waste form container shall not contain organic materials" (Randklev 1983). Thus if the TRUW were to go to the BWIP or another repository with this requirement, it may well be expected that the TRLIW would have to meet this requirement as well. 


\subsubsection{Regulations Related to Other Waste Form Characteristics}

Other considerations related to waste form characteristics are given in the composite of waste form/canister characteristics shown in Table 4.1 . In addition to release rates, the characteristics are related to the following:

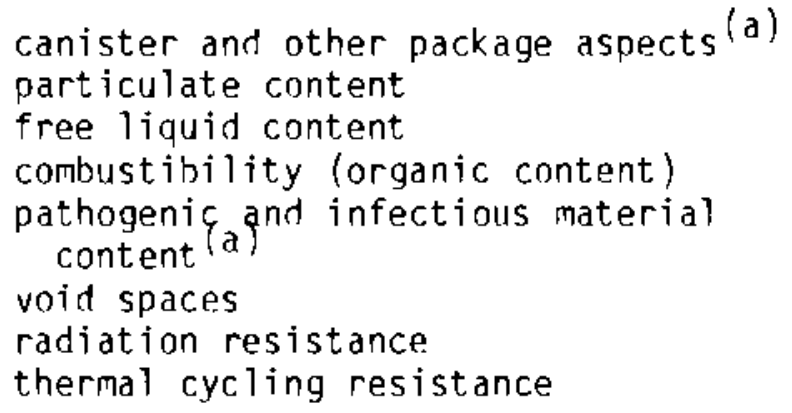

toxic vapor content explosive and pyrophoric material content gaseous radionuclide content gas generation rate structural resistance overa? 1 leach resistance homogeneity

(a) Not directly of interest in this study.

The considerations in Table 4.1 are based primarily on the assumption that minimum requirements for TRUW would he somewhat equivalent to those of $H L W$ and LLW Class $\therefore$. Additional considerations are those in 40 CFR 191 for TRIJ, the WIPP Waste Acceptance Criteria (WAC) for defense "RIJW (Westinghouse Electric Company 1984), and the draft HLW acceptance requirements for RWIP (Randlev $1983)$.

Some of the requirements given in Table 4.1 are related to the canister or waste package characteristics. However, 10 CFR 6! states that for LLW, high integrity canisters can be used to substitute for some of the required characteristics of waste forms. Although this potent:al is recognized, the evaluation of canister characteristics is not within the scope of this study.

Section 9 provides additional discussion of the requirements shown in Table 4.1 as they relate to the specific waste forms considered in this study. Additional related material is presented " $n$ Appendix $C$.

\subsection{REFERENCFS}

Anderson, K. J., et al. 1979. Engineering Evaluation of Waste Handling and Storage Facilities. AGNS-35907-4.2-26, Allied-General Nuclear Services, BarnweT, South Carolina. 
Anderson, K. J. and T. A. Evans, 1983. An Evaluation of General Process Trash Disposal by Compaction. ONI/3142/RD-03, ATlied-General Nuclear Services, Barnwel1, South Carolina.

Boone, F. W. , and P. E. Fbel. 1983. Feasibility Evaluation of Disposing of Spent Fuel and Fittings at a Shallow-Land Burial Site. ONI/3141/RD-01, Allied-Generat Nuclear Services, Barnwell, South Carolina.

Chem-Nuclear Systems, Inc. 1984. Barnwell Low-Level Radioactive Waste Disposal Facility Rate Schedule. Chem-Nuclear Systems, Inc., Barnwell, South Carolina.

Clark, L. L., et at. 1983. RECON: A Computer Program for Analyzing Repository Economics. PNL-4466, Pacific Northwest Laboratory, Richland, Washington.

Darr, D. G. 1983. Waste Model Characteristics Study: Evaluation of Reprocessing Waste Estimates. D0E/3156/FR-01, Allied-General Nuclear Services, BarnwelT, South Carolina.

Kaiser Engineers Inc./Parsons, Brinkerhoff, Quade, and Douglas, Inc. 1983. Conceptual System Design Description, Nuclear Waste Repositories in Basalt, Project B-301. BWI-SD-006, RockwelT Hanford Operations, Richtand, Washington.

Mckee, R. W., L. L. Clark, P. M. Daling, J. F. Nesbitt, and J. L. Swanson. 1984. "Economic Analysis of Waste Management System Alternatives for Reprocessing Wastes." Waste Management 1984, pp. 383-393. University of Arizona, Tucson.

Randk lev, E. H. 1983. Draft Waste Acceptance Requirements for the Basalt Waste Isolation Project. SD-BWI-CR-018, Rockwell Hanford Operations, Richland, Washington.

U.S. Department of Energy. 1979. Technology for Commercial Radioactive Waste Management. DOE/ET-0028 in 5 volumes, U.S. DOE, Washington, D.C.

U.S. Department of Transportation. 1984. Code of Federal Regulations, Tit7e 49, Transportation (subchapter C - Hazardous Material ReguTations); Part 171, General Information, Regulations and Definitions; Part 172, Hazardous Materials Table and Hazardous Materials Communications Regulations; Part 173, Shippers General Requirements for Shipments and Packagings; Part 174, Carriage by Rail; Part 177, Carriage by Public Highway; Part 178, Shipping Container Specifications. Revised January 1, 1982. IJ.S. DOT, Washington, D.C. 
U.S. Environmental Protection Agency. 1984a. Code of Federal Regulations, Title 40, Protection of Environment; Part 190, Environmental Protection Standards for Nuclear Power Operations. Revised Jarıuary 1, 1984. U.S. EPA, Washington, ח.C.

II.S. Environmental Protection Agency. 1984b. Fourth Working Draft. Code of Federal Regulations, Tit\}e 40, Protection of Environment; Part 191, Environmental Radiation Protection Standards for Management and Disposal of Spent Nuclear Fuel, High-Level, and Transuranic Radioactive Wastes. April 17, 1984. U.S. EPA, U.S. Public nocument Room, Washington, n.C.

U.S. Environmental Protection Agency. 1985. Fifth Working Draft. Code of Federal Regulations, Title 40, Protection of Environment; Part 191, Fnvironmental Radiation Protection Standards for Management and Disposal of Spent Nuclear Fuel, High-Level and Transuranic Radioactive Wastes. March 21, 1985. U.S. EPA, U.S. Public Document Room, Washington, N.C.

U.S. Nuclear Regulatory Commission. 1983. Low-Level Licensing Branch Technical Portion on Radioactive Waste Classification. May 1983, Revision D. U.S. NRC, Washington, D.C.

U.S. Nuclear Regulatory Commission. 1984a. Code of Federal Regulations, Title 10, Energy; Part 60, Disposal of High-Level Radioactive Wastes in Geologic Repositories (Subpart E, Technical Criteria). Final Rule, U.S. Federal Register, Vol. 48, No. 120, June 21, 1983, pp. 28194-28229. U.S. NRC, Washington, ก.C.

U.S. Nuclear Regulatory Commission. 1984b. Code of Federal Regulations, Title 10, Energy; Part 61, Licensing Requirements for Land Disposal of Radioactive Waste, Final Rule. II.S. Federal Register, Vol. 47, necember 27, 1982 (Effective January 26, 1983), P. 57463. II.S. NF.C, Washington, D.C.

U.S. Nuclear Regulatory Commission. 1984C. Code of Federal Regulations, Title 10; Energy; Part 20, Standards for Protection Against Radiation. Revised January 1, 1983. U.S. NRC, Washington, D.C.

U.S. Nuclear Regutatory Commission. 1984d. Code of Federal Regulations, Title 10, Energy; Part 71, Packaging and Transportation of Radioactive Material. U.S. Federal Register, Vol. 48, p. 35607, August 5, 1983; p. 38449, August 24, 1983. U.S. NRC, Washington, D.C.

Westinghouse Electric Company. 1984. TRU Waste Acceptance Criteria for the Waste Isolation Pilot Plant. WIPP-D0E-069, Rev. 2 , Draft C, Albuquerque, New Mexico. 


\subsection{DEFINITION OF TRUW STREAMS}

The TRUW quantities and radionuclide contents used in this report are primarily as estimated by Allied-General Nuclear Services (AGNS) personnel for operation of the BNFP (Darr 1983). Those estimates that were modified by the authors of this report are discussed later in this section. The wastes and the containers that the BNFP staff planned to use are briefly described and the quantities are summarized in a series of tables. Only the waste streams in Darr (1983) that are indicated to be TRUW are taken as such. This assumes that an efficient assay system is in place in the existing facility to discriminate accurately between streams that are IRUW and those that could be, but are not, TRUW.

\subsection{ORIGIN OF GENERAL TRUW TYPES AT THE REFERENCE FUEL REPROCESSING PLANT}

The hulls and hardware are the metallic (Zircaloy, Inconel, and stainless steel) portions of the spent fuel elements; these portions remain after the elements are sheared and the uranium dioxide fuel is dissolved out with nitric acid during reprocessing. The hulls and hardware are not only the most voluminous and heaviest TRUW type, they are also the most highly radioactive.

The general process trash (GPT) waste contains both combustible (e.g., paper, cloth, plastics, rubber) and noncombustible (e.g., metal, glass, cement) materials. The sample and analytical cell (SAC) waste is similar to the GPT waste.

Used HEPA filters comprise a large volume waste stream that presents some challenging treatment problems. The filters have either wooden or metallic frames and noncombustible (e.g., glass, asbestos) or combustible (e.g., filter paper) filter media. They also contain an appreciable amount of organic materials in the form of adhesives and rubber gaskets. Some filters also contain separators made of aluminum.

Failed equipment comprises another metallic (primarily stainless steel) waste stream. Darr's (1983) estimates indicate that this is a low volume waste stream. The BNFP staff planned to store large pieces of failed equipment 
onsite until the plant was decomissioned, at which time the failed equipment wotld he treated along with (and considered as) decommissioning waste.

Fluorinator solids are a residue of fluorination of the uranium product of the reprocessing plant. This waste stream is composed primarily of alumina and calcium fluoride particulates.

\subsection{BASES FOR TRUW DESCRIPTIONS}

The Darr study (1983) described 18 different waste streams that are classified as TRIJW. Many of these were further categorized according to container size, TRU content, and surface dose rate. The study also descrihed other streams of similar wastes that did not contain enough TRIl activity to be classed as TRUW; these streams are not addressed here.

For our study it was necessary to determine the relative amounts of combustible and noncombustihle materials in the wastes. A clear distinction of these two types was difficult to obtain from the Darr study for GPT and SAC wastes. Most of the difficulty came from the distinctions made by the BNFP staff between the fraction of the waste containers in which at least a portion of the waste is combustihle, and the fraction of the contained waste which is comhustible. Unless the waste is segregated, these fractions are not necessarily the same. The information listed in Appendix $C$ of the Darr stury does not provide all of the information needed to evaluate alternative waste treatment options.

The following hases for the GPT and SAC wastes were adopted based on some of the values from the Darr study, compined with the authors" knowledge of waste compositions and handling practices:

- The GPT wastes are segregated at the point of origin, so that the fraction of the combustible waste is equal to the fraction of the CPT containers that contain combustihle wastes. All of the GPT wastes are 80 vol\% combustible and 20 vol\% noncombustible materials. Oniy for the GPT from the Plutonium Product Facility do these hases give quantities different from those given in the Darr study. 
- The SAC wastes are not segregated at the point of origin, so all of the containers contain both combustible and noncombustible wastes, as indicated in Appendix $C$ of the Darr study. Each SAC waste container holds a mixture of 60 vol\% combustible and 40 vol\% noncombustible waste; these somewhat arbitrary fractions are based on the authors' interpretation of information for SAC waste stream 23 in Appendix $B$ of the Darr study. These bases give different quantities than those in Darr's Appendix C for both of the SAC waste streams.

- The weight percentages of the combustible and noncombustible portions of the GPT and SAC streams are the same as the volume percentages. This basis is admittedly arbitrary but should be fairly appropriate, since Darr applied the same weight per drum to all of the drums of GPT waste, even though he appears to have assumed that segregation had occurred.

Another important consideration not evident in the BNFP staff estimates is that all HEPA filters, even those with metal frames, contain an appreciable amount of organic material. All of this waste stream must therefore be considered partially combustible, even though Darr applied that designation only to the wood-framed filters.

These bases/assumptions have no effect on the Darr estimates of initial waste volumes and numbers of containers. However, they are important for the considerations of alternative waste treatment processes in this study.

\subsection{TRUW QUANTITIES}

The tables presented in this section summarize the number of containers for the wastes and the volumes, weights, and radiation levels of the TRUW. These sumaries were derived from the detailed values given in Appendix A, which were modified as indicated above from the Darr study.

The wastes are divided into contact-handled $(\mathrm{CH})$ and remotely handled (RH) categories. Contact-handled waste is waste having a radiation dose rate below $200 \mathrm{mR} / \mathrm{hr}$ at the surface of the container. The remotely handled TRUW is also characterized in several dose rate ranges. 
The containers planned for the BNFP wastes as they were generated were 50-, 80-, and 600-gal drums (see Appendix $B$ for physical measurements of these drums). The standard 55-gal drum was planned to he used extensively. Because the standard HEPA filters do not fit into a 55-gal drum, standard 80-gal drums (military specification 27683) were to be used to contain most of these wastes. Specially designed 600-gal stainless steel containers equipped for rerlote handling were to be used to contain the hulls and hardware, the larger pieces of failed equipment, the SAC wastes, and the most highly radioactive HEPA filters.

Table 5.1 contains a summary of the Darr estimates of the numbers of initial waste containers produced each year to reprocess spent fuel at a rate of 1,500 MTU/yr. The initial containers are those in which the wastes are collected and moved from the part of the facility where they were generated. The results are tabulated by container size and type of waste and are allocated among several dose rate ranges. These values are based on the data contained in Darr (Appendix C), without including the container weight in defining the TRU level. (Note that if the weight of the container had been included, there would have been some decrease in the quantity of TरUW and a corresponding increase in the quantity of C,lass C. LLW. The overall effect of this change, however, would he small.)

The wastes from the iodine retention operations are excluded from Table 5.1 and from subsequent consideration, since technically they are not TRUw because of the special disposal requirements for such wastes and because of their small volume. The use of appropriate operating practices, including waste assay techniques, is assumed in this study to support this basis.

Table 5.2 contains a summary of the volumes occupied by the initial containers, again using values provided by Darr. In this and subsequent tables the quantities are given per MTU processed. The volumes in this table represent the volumes of waste to be disposed of if disposal in the initial containers is possible.

The volumes of untreated wastes before they are placed in the injtial containers are given in Table 5.3. These values represent the starting volumes 
TABLE 5.1. Containers per Year of Untreated TRUW(a)

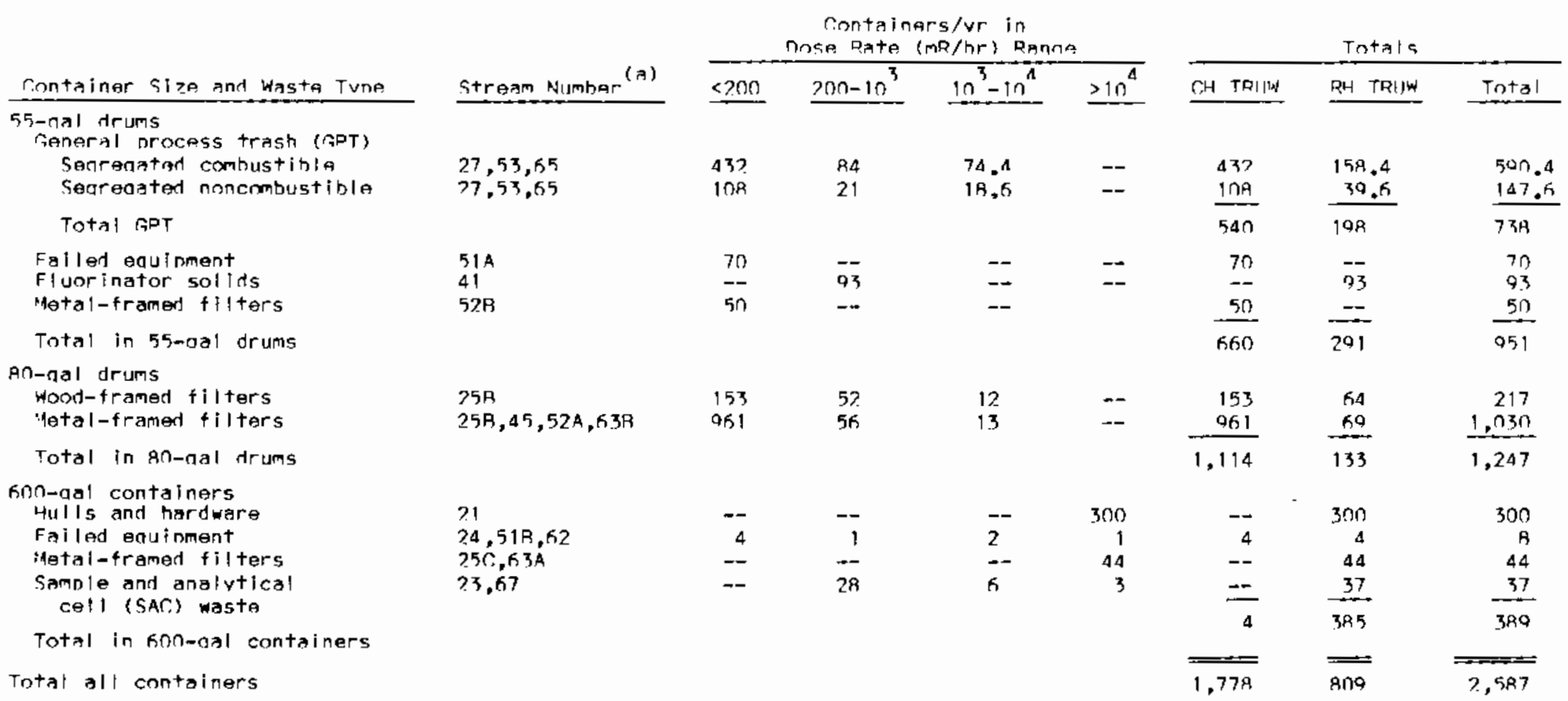

(a) nata and stream numbers are taken from narr (1983) for reorocessina 1,50n kTIJ/vr. rontainer weiahts not included in rafininn TRIlw lovel. Wastes from intine retantion onerations not included (7h 55-nal. drums/vr). Values mav be converted to drums/MTli be tividing be 1,500 . 


\section{TABLE 5.2. Annual Volumes of Containers of Untreated TRUW (a)}

\begin{tabular}{|c|c|c|c|c|c|c|c|c|}
\hline \multirow[b]{2}{*}{ Contbiner Size and Waste Type } & \multirow[b]{2}{*}{ Stream Number ${ }^{(a)}$} & \multicolumn{4}{|c|}{$\begin{array}{l}\text { Volume of TRIlw in indicated } \\
\text { Dose Rate (mR/hr) Range, } \mathrm{m}^{3} / \mathrm{MTl}\end{array}$} & \multicolumn{3}{|c|}{ Totals } \\
\hline & & 200 & $200-10^{3}$ & $10^{3}-10^{4}$ & $>10^{4}$ & CH TRIJW & $\mathrm{RH}$ TR! IW & Total \\
\hline $\begin{array}{l}\text { 55-nal drums } \\
\text { Ganaral orocess trash (GPT) }\end{array}$ & $\begin{array}{l}27,53,55 \\
27,53,65\end{array}$ & $\begin{array}{l}0.074 \\
0.010\end{array}$ & $\begin{array}{l}0.014 \\
0.0036\end{array}$ & $\begin{array}{l}0.013 \\
0.0032\end{array}$ & -- & $\begin{array}{l}0.074 \\
0.019 \\
\end{array}$ & $\begin{array}{l}0.027 \\
0.0068 \\
\end{array}$ & $\begin{array}{l}0.101 \\
0.026 \\
\end{array}$ \\
\hline Total Rat & & & & & & 0.003 & 0.034 & 0.127 \\
\hline $\begin{array}{l}\text { Fafled equinment } \\
\text { Fluor Inator solids } \\
\text { Metal-framed filters }\end{array}$ & $\begin{array}{l}51 A \\
41 \\
57 B\end{array}$ & $\begin{array}{l}0.017 \\
0.0 n 86\end{array}$ & $\begin{array}{l}0.016 \\
--\end{array}$ & $\begin{array}{l}-- \\
-- \\
--\end{array}$ & $\overline{--}$ & $\begin{array}{l}0.012 \\
-0.0086 \\
\end{array}$ & $\begin{array}{l}-- \\
- \\
-\end{array}$ & $\begin{array}{l}0.012 \\
0.016 \\
0.0086 \\
\end{array}$ \\
\hline Total in 55-oal drums & & & & & & 0.114 & 0.050 & 0.164 \\
\hline $\begin{array}{l}\text { gn-aal drums } \\
\text { woon-framed filters } \\
\text { Matal-framed filters }\end{array}$ & $\begin{array}{l}25 \mathrm{~A} \\
25 \mathrm{~A}, 45,52 \mathrm{~A}, 63 \mathrm{~B}\end{array}$ & $\begin{array}{l}0.036 \\
0.225\end{array}$ & $\begin{array}{l}0.012 \\
0.013\end{array}$ & $\begin{array}{l}0.002 \mathrm{R} \\
0.0030\end{array}$ & 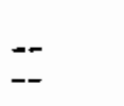 & $\begin{array}{l}0.036 \\
0.225 \\
\end{array}$ & $\begin{array}{l}0.015 \\
0.016 \\
\end{array}$ & $\begin{array}{l}0.051 \\
0.241 \\
\end{array}$ \\
\hline Total in 8 n-qal drums & & & & & & 0.261 & 0.031 & 0.292 \\
\hline $\begin{array}{l}\text { 600-aal containers } \\
\text { Hulls and hardware } \\
\text { Falled eaufoment } \\
\text { hetal-framed filters } \\
\text { Samnle and analvtical } \\
\text { cell (SAC) waste }\end{array}$ & $\begin{array}{l}21 \\
24,51 \mathrm{~B}, 62 \\
25 \mathrm{C}, 63 \mathrm{~A} \\
23.67\end{array}$ & $\begin{array}{l}-- \\
0.0064 \\
--\end{array}$ & $\begin{array}{l}- \\
0.0016 \\
-0.045\end{array}$ & $\begin{array}{l}-0 \\
0.0032 \\
0.010\end{array}$ & $\begin{array}{l}0.482 \\
0.0016 \\
0.071 \\
0.0048\end{array}$ & $\begin{array}{l}-\infty \\
0.0064 \\
-- \\
\end{array}$ & $\begin{array}{l}0.482 \\
0.0064 \\
0.071 \\
0.059 \\
\end{array}$ & $\begin{array}{l}0.482 \\
0.013 \\
0.071 \\
0.059 \\
\end{array}$ \\
\hline Total in 600 -aal drums & & & & & & 0.0064 & 0.618 & 0.625 \\
\hline Total all containers & & & & & & 0.381 & 0.599 & $1 . \cap 81$ \\
\hline
\end{tabular}

(a) Data and stream numbers are taken from narr (1983).

Volume values wers obtained from:

intainars/yr from Table 5.1.

Volumes ocopied reprocissing rata.

55-gal drum accupias $0.258 \mathrm{~m}_{3}^{3}(9.1 \mathrm{ft} 3)$.

Bo-gal drim occupies $0.351 \mathrm{~m}^{3}\left(12.4 \mathrm{ft}^{3}\right)$.

- 500-jal containar occupias $2.41 \mathrm{~m}^{3}\left(95 \mathrm{ft}^{3}\right)$. 
TABLE 5.3. Unit Volumes of Untreated TRUW Before Containerization (a)

\begin{tabular}{|c|c|c|c|c|c|c|c|c|}
\hline \multirow[b]{2}{*}{ Container size and waste Type } & \multirow[b]{2}{*}{ Stream Number ${ }^{(a)}$} & \multicolumn{4}{|c|}{$\begin{array}{l}\text { volume of TRIIW in Indicated } \\
\text { Dose Rate (mR/hr) Range, } \mathrm{m}^{3} / M T U\end{array}$} & \multicolumn{3}{|c|}{ Totals } \\
\hline & & 200 & $200-10^{3}$ & $10^{3}-10^{4}$ & $>10^{4}$ & $\mathrm{CH}$ TRIJW & RH TRUWW & Total \\
\hline $\begin{array}{l}\text { 55-qat drums } \\
\text { Seneral orocess trash ((FDT) } \\
\text { Searanated combustible } \\
\text { Seareaated noncombustible }\end{array}$ & $\begin{array}{l}27,53,65 \\
27,53,65\end{array}$ & $\begin{array}{l}0.056 \\
0.0140\end{array}$ & $\begin{array}{l}0.0113 \\
0.00283\end{array}$ & $\begin{array}{l}0.0100 \\
0.00251\end{array}$ & $\begin{array}{l}-- \\
--\end{array}$ & $\begin{array}{l}0.056 \\
0.0140 \\
\end{array}$ & $\begin{array}{l}0.0214 \\
0.00534 \\
\end{array}$ & $\begin{array}{l}0.0774 \\
0.0193 \\
\end{array}$ \\
\hline Total GDT & & & & & & 0.070 & 0.0267 & 0.0967 \\
\hline $\begin{array}{l}\text { Failed equinment } \\
\text { Jarticulate solids } \\
\text { Hetal-framed filters }\end{array}$ & $\begin{array}{l}51 \mathrm{~A} \\
41 \\
52 \mathrm{~B}\end{array}$ & $\frac{0.00944}{0.00283}$ & $\vec{n} .0117$ & $\begin{array}{l}-- \\
--\end{array}$ & $\begin{array}{l}z \\
z\end{array}$ & $\begin{array}{l}0.00944 \\
-0.00283 \\
\end{array}$ & $\begin{array}{l}-0.0117 \\
-\end{array}$ & $\begin{array}{l}0.0094 \\
0.0117 \\
0.0028 \\
\end{array}$ \\
\hline Total in 55-aal drums & & & & & & 0.0823 & 0.0384 & 0.121 \\
\hline $\begin{array}{l}\text { 80-aal drums } \\
\text { itood-framed filters } \\
\text { 'fotal-framed filters }\end{array}$ & $\begin{array}{l}25 B \\
25 R, 45,52 A, 63 R\end{array}$ & $\begin{array}{l}0.0102 \\
0.0555\end{array}$ & $\begin{array}{l}0.00347 \\
0.00363\end{array}$ & $\begin{array}{l}0.00054 \\
0.00087\end{array}$ & -- & $\begin{array}{l}0.0102 \\
0.0655\end{array}$ & $\begin{array}{l}0.00401 \\
0.00449 \\
\end{array}$ & $\begin{array}{l}0.0142 \\
0.0700 \\
\end{array}$ \\
\hline Total in 80-qal Arums & & & & & & 0.0757 & 0.0085 & 0.0842 \\
\hline $\begin{array}{l}\text { fon-dal containers } \\
\text { tulls and hardware } \\
\text { Failes anuloment } \\
\text { Metal-tramed filters }\end{array}$ & $\begin{array}{l}21 \\
24,51 \mathrm{~A}, 62 \\
25 \mathrm{C}, 53 \mathrm{~A}\end{array}$ & $\begin{array}{l}-- \\
0.0037 \mathrm{~A}\end{array}$ & $\begin{array}{l}-- \\
n .00094\end{array}$ & $\begin{array}{l}-- \\
n .00227\end{array}$ & $\begin{array}{l}0.425 \\
0.00094 \\
0.0113\end{array}$ & $\overline{0.00378}$ & $\begin{array}{l}0.425 \\
0.0042 \\
0.0113\end{array}$ & $\begin{array}{l}0.425 \\
0.0080 \\
0.0113\end{array}$ \\
\hline cell (SAC) waste & $2.3,67$ & -- & 0.0107 & 0.00529 & 0.00215 & $\underline{--}$ & 0.0191 & 0.0191 \\
\hline Total in fonn-nal containers & & & & & & 0.00378 & 0.460 & 0.463 \\
\hline Total all wastes & & & & & & 0.1618 & 0.507 & 0.66 .8 \\
\hline
\end{tabular}

(a) nata and stream numbers are taken from Darr (1983). 
for waste treatment processes and are occasionally much smaller than the volumes of the initial containers because of inefficient packing; this is especially important with filters that are packaged individually in drums. These volumes of untreater wastes were ohtained by calculating the volumes of untreated wastes per container from the data in Appendix $B$ of the Darr study and by multiplying those values hy the number of containers filled per MTIs processed.

Table 5.4 contains the weight of the various wastes. These data also come directly from the Darr study.

Table 5.5 presents a summary comparison of the volumes of the initial waste containers containing the different types of wastes. Because of their initially high volumes and low packing density, the potential volume reductions are the greatest for the hulls and hardware, the filters, and the GPT.

The potential impact of a plus-or-minus threefold uncertainty in the Darr radionuclide content estimates on the TRIJ quantities is addressed in Table 5.6. This uncertainty range, chosen arbitrarily, has relatively little effect on the volume of the various classes of most of the waste types. However, the fluorinator solids provide a case in which a large degree of variability could occur; the quantity of TRUW of this zype could vary from zero to 4 times the quantity that is based on the ASNS eszimate. This large a variability should he kept in mind when designing and evaluating alternative treatment processes for this waste.

\subsection{REFERENCE}

Darr, D. G. 1983. Waste Model Characteristics Study: Evaluation of Reprocessing Waste Estimates. D0E/3156/FR-01, Allied-General Nuclear Services, Rarnwe11, South Carolina. 
TABLE 5.4. Unit weights of Untreated TRUW Before Containerization(a)

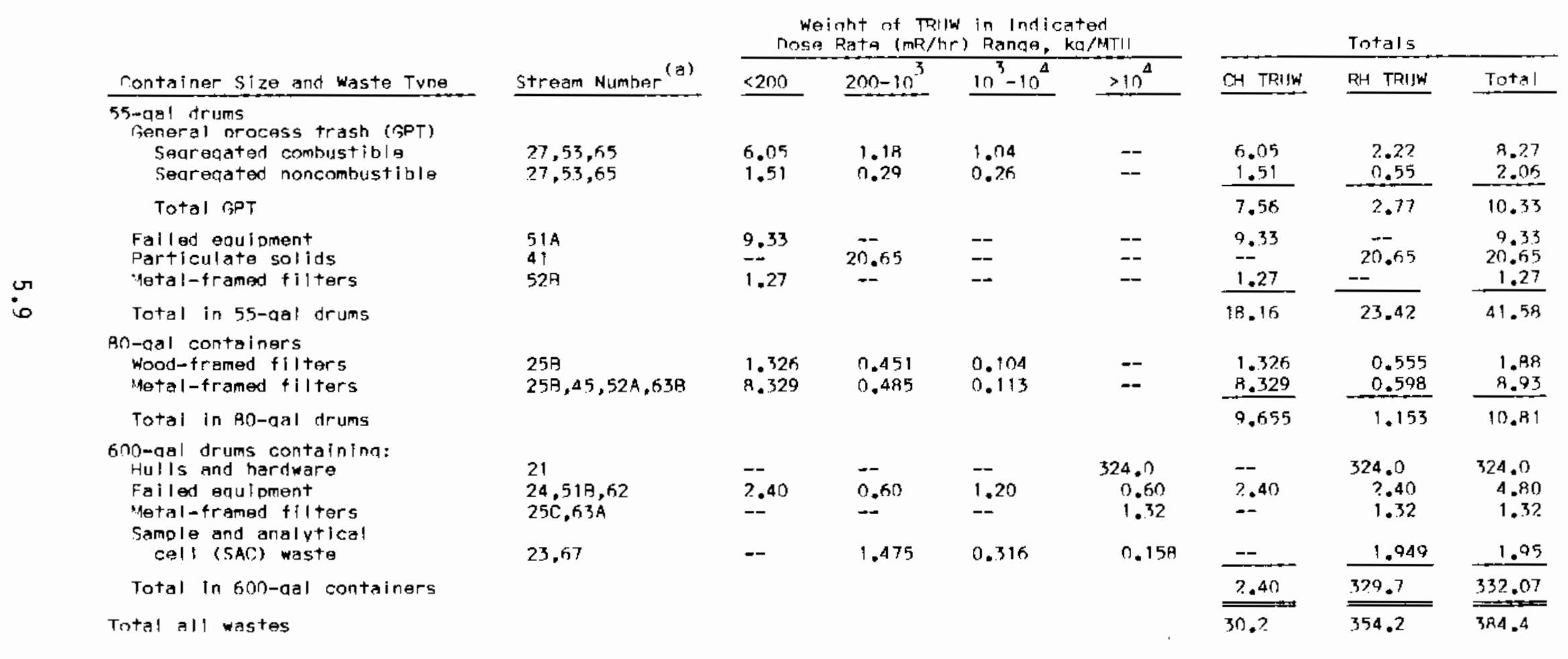

(a) Data and stream numbers are taken from narr (1993). 
TABLE 5.5. Comparison of Untreated TRUw Quantities

\begin{tabular}{|c|c|c|c|c|c|c|}
\hline \multirow[b]{2}{*}{ Waste } & \multicolumn{3}{|c|}{$\begin{array}{c}\text { Volume of Init|fal waste } \\
\text { Packanes, m3/MTHM }\end{array}$} & \multirow{2}{*}{$\begin{array}{c}\text { Volum of waste } \\
\text { Retore Packanina, } \\
m^{3} / M^{-H M} \\
\end{array}$} & \multirow{2}{*}{$\begin{array}{l}\text { Injtial } \\
\text { Packaninn } \\
\text { Factor } \\
\end{array}$} & \multirow{2}{*}{$\begin{array}{c}\text { Mensitv of waste } \\
\text { Refore Packaninn, } \\
\mathrm{kn} / \mathrm{m}^{3}\end{array}$} \\
\hline & C.H TR: & RH TRIJW & Total TRIJw & & & \\
\hline Hulls and hardware & -- & $0.48 ?$ & $0.4 \mathrm{A2}$ & 0.425 & 0.9 & 760 \\
\hline Filters & 0.270 & 0.102 & 0.372 & 0.099 & 0.3 & 130 \\
\hline GPT & 0.093 & 0.034 & 0.127 & $0.09^{-1}$ & 0.9 & 100 \\
\hline SAC waste & - & ก. .5999 & $0.059 R$ & 0.018 & 0.3 & 100 \\
\hline Failer enuinment & 0.0184 & 0.0064 & 0.0732 & $0.01 \div 4$ & $n \cdot R$ & $60 n-7 n n$ \\
\hline Fluorinator solids & $r-$ & 0.015 & 0.016 & 0.017 & 0.7 & 1800 \\
\hline Total & 0.381 & 0.700 & 1.09 & 0.565 & & \\
\hline
\end{tabular}

\section{TABLE 5.6. Maximum Possible Variation in Initial Waste Quantities Resulting from Plus or Minus Three-Fold Uncertainties in TRU Radionuclide}

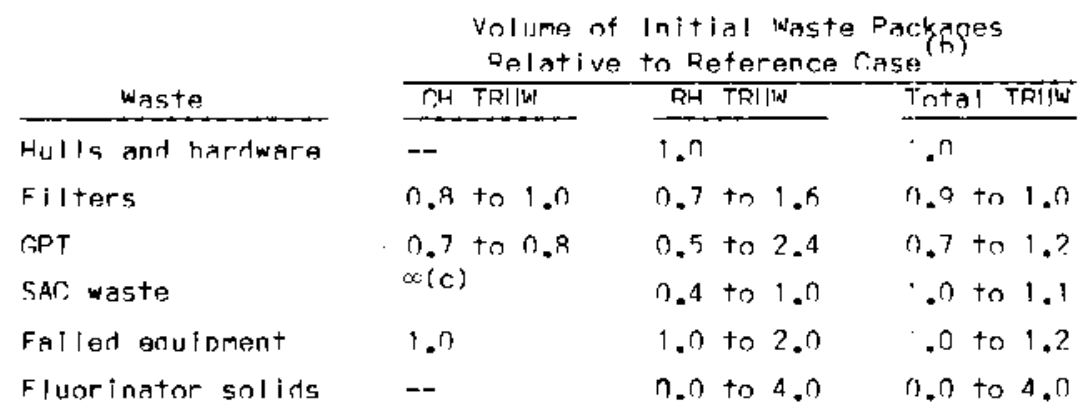

(a) Assuming that all containers for which classification could be chanaed in a ilven direction by a three-fold channe in radionuclide concentration were chanoed in that direction.

(b) Values for the reference case are given in Table 5.5 .

(c) There is no $\mathrm{CH}$ TRIlw in the reference case. 


\subsection{SELECTION OF WASTE TREATMENT OPTIONS}

Both the types of wastes and the types of treatment processes need to be considered in the selection of waste treatment options. The types of wastes were described in Section 5. In this section the types of treatment and a selection of treatment methods for each waste type are presented for the six options identified in Section 3.

\subsection{TREATMENT PROCESSES}

The treatment processes that could be applied to each of the wastes were considered. The results are summarized in Table 6.1 and discussed briefly below. They are grouped by pretreatment, intermediate treatment, and immobilization. The no treatment option is also included. As shown, the treatment processes can be used for more than one type of waste, and several processes are available for each waste type. For pretreatment,

- all wastes will be assayed at least once (and possibly several times) as they are processed to allow sorting between TRUW and LLW and between $\mathrm{CH}$ and $\mathrm{RH}$

- segregation of the wastes will be required for some processing techniques such as incineration--segregation could be performed at the waste generation point or at a central point

- size reduction or shredding of the wastes will be necessary for several of the processes.

Several intermediate methods for preparing the wastes for immobilization or further treatment were considered:

- Decontamination can be used to concentrate contamination in a smaller mass of decontamination residues and thus allow a change in classification of the majority of the waste from TRUW to LLW.

- Metallic wastes can be oxidized and then treated as a ceramic for incorporation into cement, glass, or other forms. oxidation could also he used to reduce the volume of odd shapes and sizes to allow higher bulk densities. 
TABLF. 6.1. Applicability of Treatment Method To Waste Types

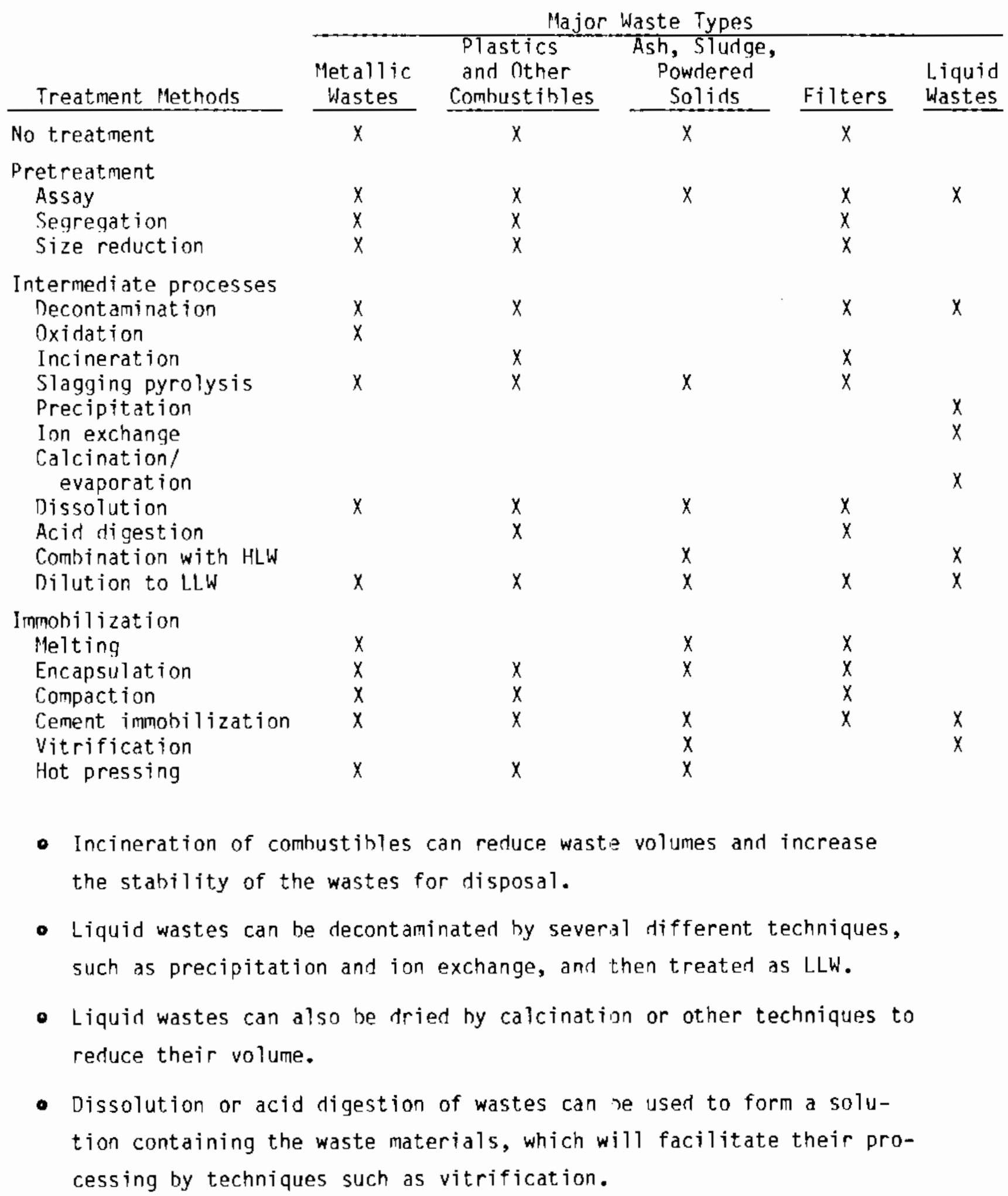


- A small volume waste stream can be incorporated into another waste stream (such as HLW) if the two streams are chemically compatible.

- If the wastes are slightly over the $100 \mathrm{nCi} / \mathrm{g}$ limit for low-level classification, they may become LLW if they are immobilized for disposal by cementation or some other technique that increases their mass. Intentional dilution for reducing the classification of wastes is not expected to be politically acceptable on a large scale, but it may be appropriate for some streams, i.e., those in which conversion to a better final form is indicated, and in which the conversion process itself provides dilution.

The final immobilization processes prepare the wastes for transportation, interim storage, and disposal. Some of these processes are listed below.

- Melting provides the highest volume reduction. Most materials can be me1ted, although processing at very high temperatures can be difficult and/or complex, and the volatility of some radionuclides may cause secondary processing difficulties.

- Wastes can be encapsulated in a variety of materials with or without size reduction.

- Compaction of the wastes is a simple technique to provide volume reduction, but it does not improve the durability of the wastes.

- Waste may be immobilized in cement, either by encapsulation or by incorporation of waste ions into the cement microstructure.

- Slagging pyrolysis has been considered for TRUW, since it can potentially treat all waste types in one unit. However, it was not given serious consideration in this study because of previous unresolved problems (Tait 1983).

- The potential use of hot pressing for metals, oxides, or selected plastic and rubber has also been recognized but has not been tested for many of these wastes. A process unit could have very different characteristics, depending on the wastes to be treated. 


\subsection{SELECTION OF TREATMENT DBJECTIVES}

As shown in Table 6.1, most treatment methods are only applicable for specific waste types. Even if applicable, treatment may not be optimal for certain waste types. A goal of this study was to include as many of the treatment options as possible for preliminary evaluation. To allow this and to provide a focus for the study, several potential overall strategy ohjectives were identified, and these are summarized below.

6.2.1 Option 1 - No Treatment

In this option the waste generator (reprocessor) generally prefers to minimize treatment costs, even if doing so increases transportation and disposal costs. Wastes are disposed of as they are generated, without considering their chemical durability, combustibility, or final packaged volumes. The wastes are packaged in containers of the size appropriate to the waste size and to allow efficient handling. Containers of 55-, 80-, and 600-gal capacity were expected to he used at BNFP.

\subsubsection{Option 2 - Minimum Treatment (compaction)}

For this treatment option the major objective is simple volume reduction. This is to he accomplished with compaction (using pressures of ahout 1000 psig) in several different systems to save disposal and transportation costs. Supercompaction (using pressures of ahout 10,000 psig to ohtain greater volume reduction) is a similar process but is considered a variation of the primary method. Supercompaction may warrant further evaluation for those cases in which compaction appears to he an attractive treatment method. Some types of wastes, e.g., failed equipment, are not amenable to normal compaction processes. However, it is helieved that compaction could he applied to all solid waste types with some success.

\subsubsection{Option 3 - Minimum Number of Processes and Products (cementing)}

The objectives of this option are to reduce the volume of the wastes, to treat them to limit combustibility and increase chemical durability, and to accomplish hoth with one major treatment process. The henefits of having only one treatment process include minimizing the capital and operating costs of treatment facilities, and simplifying the characterization and qualification of 
the wastes for repository disposa1. Cementing was chosen as the sole process in this option because it is a simple and well-developed process that is applicable to all waste types and hecause it improves the disposal characteristics of the wastes as well. A major disadvantage of the process is its lack of significant volume reduction. Slagging pyrolysis is another potential option, but it is much more complex than cementing; it could he considered for cases in which further improvements to the cement waste form characteristics are needed. Recent experience with slagging pyrolysis at the Idaho National Engineering Laboratory (INEL) has not been very encouraging (Tait 1983). Cementing of the wastes would require that some wastes he pretreated by size reduction or shredding to allow them to be mixed with the cement.

\subsubsection{Option 4 - Maximum Volume Reduction Without Decontamination (melting)}

One of the major cost factors in waste disposal is the repository disposal cost. Since the repository disposal cost is a function of the volume of the wastes, minimizing the volume of TRUW should be a worthwhile objective. Thus volume reduction is the primary objective of this option; however, it is recognized that this type of processing would also significantly increase the chemical durability of the waste form, particularly if some effort were made to control and adjust compositions. To obtain the minimum volumes in this study, the combustible wastes were assumed first to be incinerated to reduce their volume and mass. Then the residual (ash and scrubber solids) and other wastes were assumed to be processed to maximum theoretical density by incorporation into metal or ceramic melts. Extensive sorting of some wastes would be necessary to facilitate processing.

\subsubsection{Option 5 - Maximum Volume Reruction with necontamination}

The primary objective of this option is to reduce the amount of material classified as TRIJW. As with Option 4, the major incentive in reducing the TRUW volume is to achieve volume and cost reductions for transportation and disposa1. Volume reduction is accomplished by removing surface contamination so that the wastes can be reclassified as LLW after careful assay. It is recognized, however, that disposal of "hotter" LLW may not be less costly than disposal of comparable levels of TRUW. The removed contamination must be disposed 
of and should be of low volume. It was therefore determined that the concentrated contamination should he combined with the HLW for vitrification. Such action will reduce the waste treatment units required in the facility (potentially reducing treatment capital and operating costs) while incorporating the wastes into a more durahle form. While most wastes could be treated hy decontamination, certain fractions of the waste that could not he decontaminated on a practical basis would need to be treated hy other processes. Hot pressing of the decontamination sludge from hulls is also considered an alternative to HLW vitrification.

\subsubsection{Option 6 - Noncombustible Waste Forms}

The objective of Option 6 is to process all wastes into forms that are expected to he acceptable for disposal. A wide variety of disposal criteria have been considered for TRUW; some of the more restrictive criteria would eliminate combustibles from the repository and would require good chemical durability (see Section 4). For this option, all metals would be melted, all combustibles eliminated by incineration, and all residual noncombustible wastes cemented with the incinerator ash and incinerator off-gas scrubber solids to make them resistant to chemical attack and dispersion.

\subsection{REFFRENCE}

Tait, T. D. 1983. Demonstration Test Assessment of the Slagging Pyrolysis Incinerator for Processing INEL Transuranic Waste. EGlG-TF-6192, Idaho Nationa? Engineering Laboratory, Idaho Falls, Itaho. 


\subsection{PROCESS DESCRIPTIONS AND WASTE NUANTITIES FOR THE SIX BASIC TRUW TREATMENT OPTIONS}

Each of the six treatment options identified in Section 6 is evaluated here, primarily in terms of its effectiveness in processing TRUW and its processing and disposal costs. Costs are discussed in Section 8 , and other processing considerations are discussed in Section 9. The effectiveness of the treatment options depends upon the waste volume reduction achieved and on the final quality of the processed waste form. Table 7.1 summarizes each treatment option for the five TRUW types (described in Section 5): hulls and hardware $(H \& H)$, failed equipment, filters, fluorinator solids, and GPT-SAC waste. For the treated and untreated waste forms, $C H$ waste is defined as waste with a surface dose rate less than $200 \mathrm{mR} / \mathrm{hr}$; waste types with surface dose rates greater than $200 \mathrm{mR} / \mathrm{hr}$ are categorized as $\mathrm{RH}$ waste. Specific surface dose rate calculations were not performed in this study; they were approximated from other analyses.

Each of the treatment options is discussed in the following section, and process and equipment flow diagrams and a summary of the final waste quantities and types are presented. The estimates of the final processed TRUW quantities are given in Appendix $B$.

Figure 7.1 depicts the overall TRUW processing operations. The block labeled "TRIW Treatment" represents the six TRIJW treatment options discussed in subsequent subsections. A new container size (160 gal) was introduced to improve the handling needs for some treated wastes. Characteristics of the various containers are given in Appendix $B$.

\subsection{OPTION 1 - NO TREATMENT}

This option involves simply packaging the TRUW as it is generated, holding it in surge storage for a short time, and then shipping it from the reprocessing plant to the waste disposal site. Figure 7.2 shows the steps involved in this option in addition to those given in Figure 7.1. Table 7.2 gives the unpackaged net weights, the unpackaged and packaged waste volumes, and the 
TABLE 7.1. Description of Each Treatment Option by Waste Type

\begin{tabular}{|c|c|c|c|c|c|c|}
\hline Ipt ' un indiste wo & 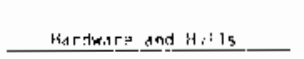 & [siler1 F.quipiner.t. & Filters & Flugrinator solins & $\begin{array}{l}\text { Tenerd Process irash } \\
\text {-and sou Waste }\end{array}$ & _._. Kena na \\
\hline I No trestment & 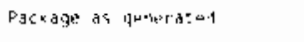 & "ack dpe as zenerated & Package as gencrated & Package as opentratert & Pacroge as generated & \\
\hline Container sizu, gal & 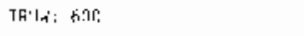 & TRllu: 55, fin & 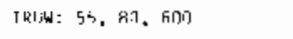 & TA:IH: 5.5 & Yरे।:W: 55,6910 & \\
\hline 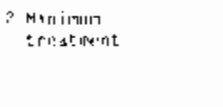 & 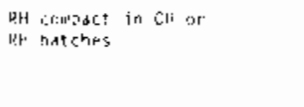 & 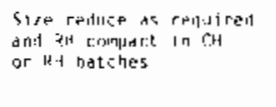 & 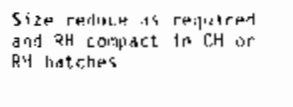 & backale as generated & 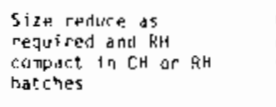 & 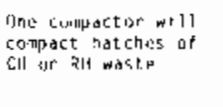 \\
\hline 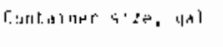 & 足 & TPII'd: | f fil & TRUH: 1 tin & $T H I \mu_{A}:=5$ & TRl:W: $15 n$ & \\
\hline 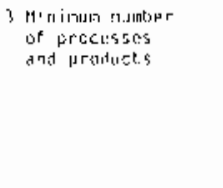 & 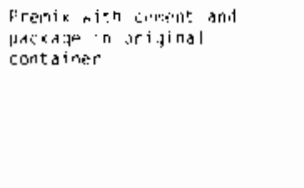 & 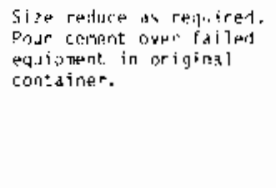 & 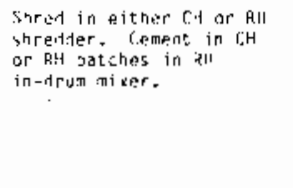 & 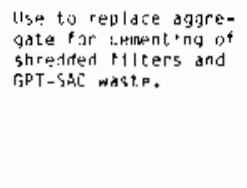 & 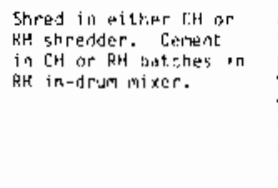 & 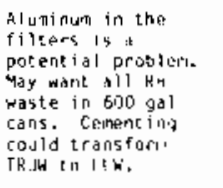 \\
\hline 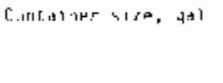 & 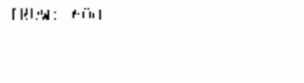 & TA'JH: 55, h:ll? & rRIL: 45 & 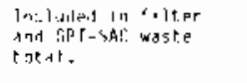 & {$[R ! I N:$ bi } & \\
\hline 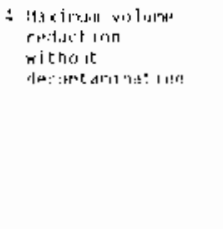 & 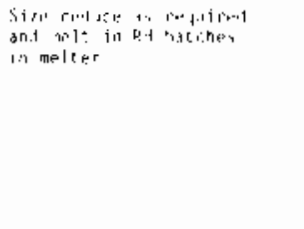 & 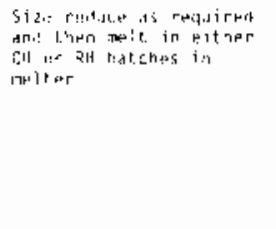 & 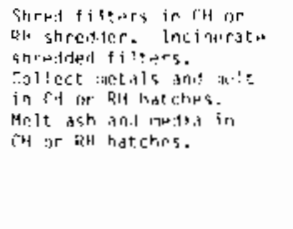 & $\begin{array}{l}\text { Melt in Rl: f:atcres in } \\
\text { me?:ater }\end{array}$ & 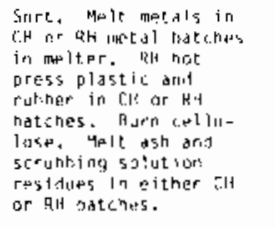 & \\
\hline 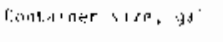 & 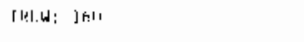 & IRI.N: !hl! & $T$ से|: & 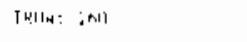 & TRेW: 1601 & \\
\hline 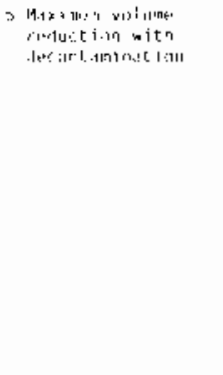 & 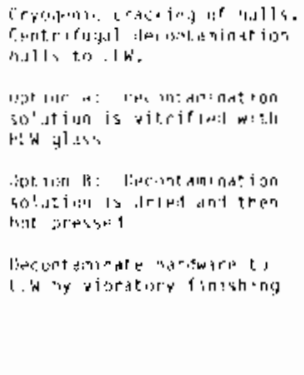 & 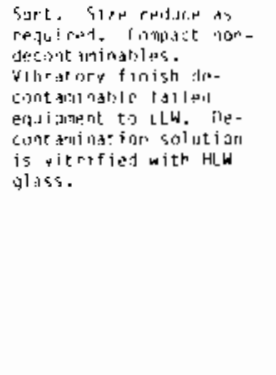 & 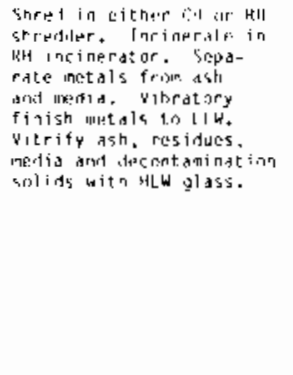 & 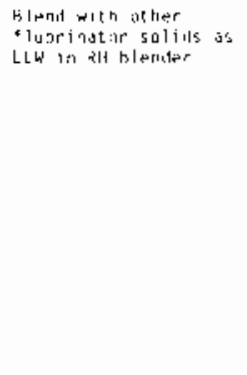 & 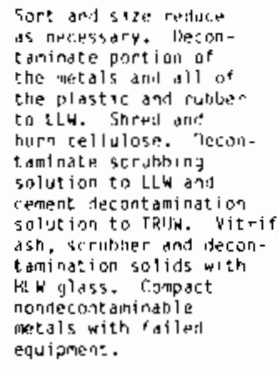 & 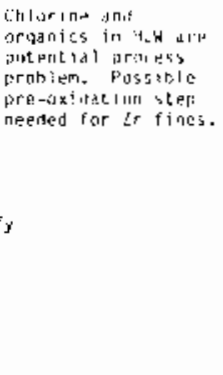 \\
\hline 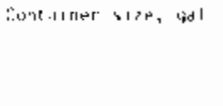 & 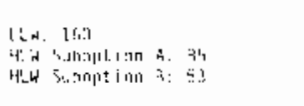 & 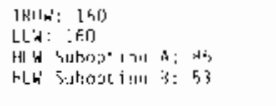 & 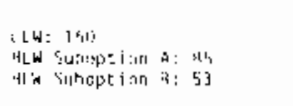 & 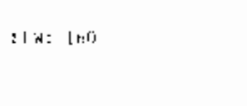 & 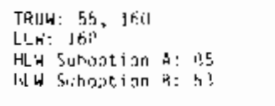 & \\
\hline 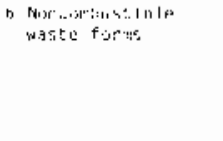 & 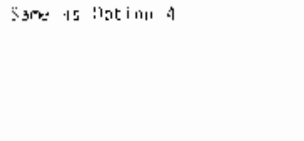 & Same as lption a & 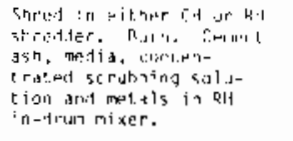 & 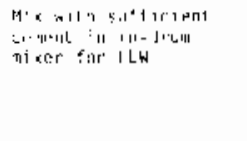 & 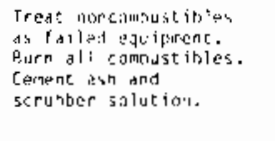 & 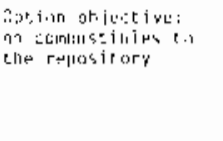 \\
\hline 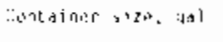 & 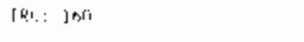 & $T R: 1: 16,1$ & [יו & LLA Ifre & P.'J: $5 \kappa, 161 \%$ & \\
\hline
\end{tabular}




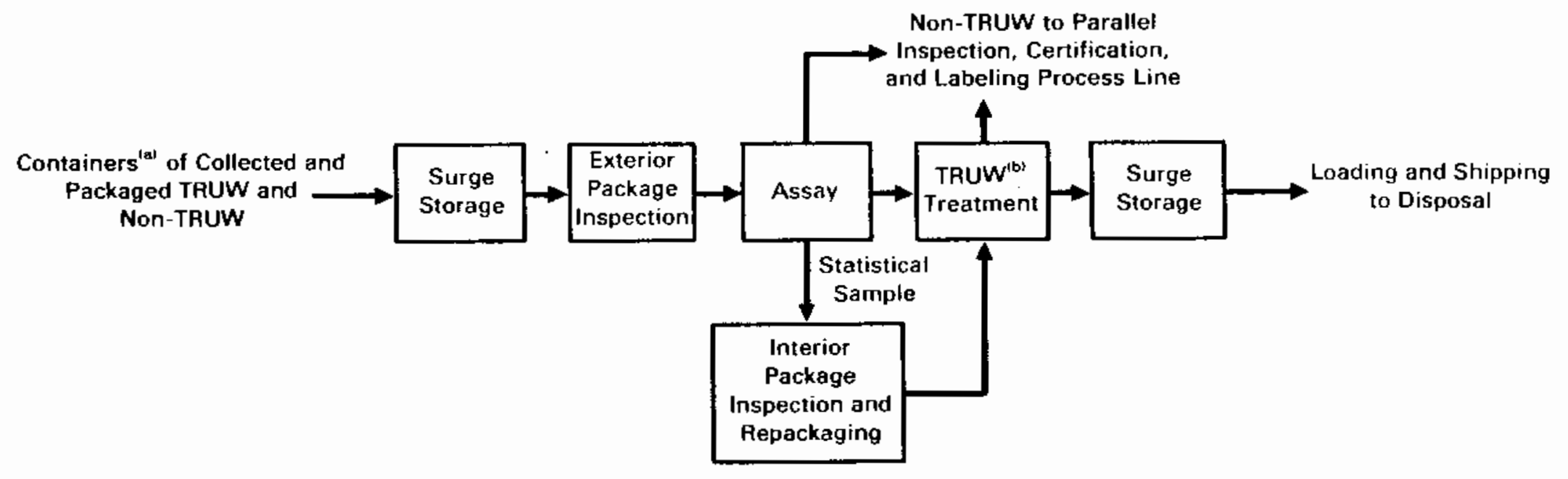

FIGURE 7.1. Process Flow Diagram for TRUW Treatment(b)

(a) These containers are from a reprocessing facility.

(b) The process flow diagram for the six TRUW treatment options studied is depicted in Figures 7.2, 7.3,7.4,7.5,7.6, and 7.7. Any inspection, sampling, certification, or labeling steps of the processed TRUW are shown as part of the TRUW treatment option. 
Containers ${ }^{(a)}$ of Collected,

Packaged, Inspected and

Assayed TRUW

- Hulls and Hardware

- Failed Equipment

- Filters

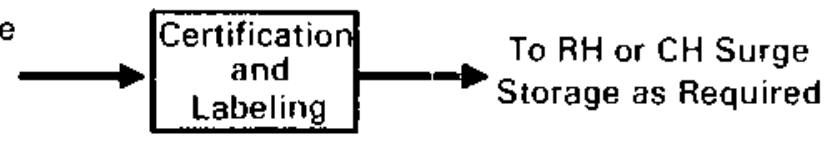

- Fluorinator Solids

- GPT-SAC Waste

FIfIJRE 7.2. Process Flow Diagram for Option 1 - No Treatment (b)

(a) These containers hold the inspected and assayed TRUW collected and packaged at the reprocessing facility, as depicted in Figure 7.1.

(b) Process steps prior to and following the ahove process step are depicted in Figure 7.1 .

canister information based on reprocessing 1,500 MTU/yr. The data are hased on values given in Section 5 .

7.? OPTION ? - MINIMLM TREATMENT (compaction)

The minimum treatment option involves physical compaction of the wastes. This treatment option assumes that some compaction can be attained for all of the waste types except fluorinator solids. (See Appendix B for bases of the compaction factors.) The compaction factors were estimated for each type of waste and were defined as the net (unpackaged) volume divided by the final compacted volume (before packaging). A compaction factor of 3.3 was assumed for the hulls and hardware. A compaction factor of 4 was assumed for the fraction of waste that Darr (1983) defined as being compactible, and a factor of 1.67 was assumed for the noncompactible fraction. Size reduction prior to compaction is required in some cases to ensure that the pieces will fit into the compactor. All the compacted waste is packaged at $9 \Gamma_{1}$ vol\% and loaded in 160 -gal containers. Since it is assumed that essentially no compaction could be attained with the fluorinator solids, they are retained in their original containers.

The compaction will increase the volumetric concentration of the radionuclides. Therefore some of the waste that was originally $\mathrm{CH}$ may become RH after compaction. Simplified calculations of dose rates were performed to 
TARLF 7.2. Weights, Volumes, and Containers of TRUW from Option 1 - No Treatment

\begin{tabular}{|c|c|c|c|c|c|c|c|}
\hline \multirow{3}{*}{$\begin{array}{l}\text { Waste } \\
\text { Type }\end{array}$} & \multirow{3}{*}{$\begin{array}{l}\mathrm{CH} / \\
\mathrm{RH} \\
\end{array}$} & \multicolumn{6}{|c|}{ Amounts/yr for $1,500 M T U / y r$ Reprocessed $(a, b)$} \\
\hline & & \multicolumn{2}{|c|}{$\begin{array}{l}\text { Net Weight } \\
\text { and Volume } \\
\end{array}$} & \multirow{2}{*}{$\begin{array}{c}\text { Packaged } \\
\text { Volume, } \\
m^{3} \\
\end{array}$} & \multicolumn{2}{|c|}{$\begin{array}{l}\text { Nomina Con- } \\
\text { tainer Size }\end{array}$} & \multirow{2}{*}{$\begin{array}{l}\text { Number of } \\
\text { Containers }\end{array}$} \\
\hline & & $\mathrm{kg}$ & $m^{3}$ & & $\mathrm{~L}$ & gal & \\
\hline $\begin{array}{l}\text { Hulls and } \\
\text { hardware }\end{array}$ & $\mathrm{RH}$ & 486,000 & 637.1 & 681.3 & 2,270 & $6 \cap 0$ & 300 \\
\hline \multirow[t]{2}{*}{$\begin{array}{l}\text { Failed } \\
\text { equipment }\end{array}$} & $\mathrm{CH}$ & 17,600 & 19.8 & 23.6 & $\begin{array}{r}210 \\
2,270\end{array}$ & $\begin{array}{r}55 \\
6 \cap 0\end{array}$ & $\begin{array}{r}70 \\
4\end{array}$ \\
\hline & $\mathrm{RH}$ & 3,600 & 6.2 & 9.1 & 2,270 & 600 & 4 \\
\hline \multirow[t]{2}{*}{ Filters } & $\mathrm{CH}$ & 16,380 & 117.6 & 347.9 & $\begin{array}{l}210 \\
300\end{array}$ & $\begin{array}{l}55 \\
80\end{array}$ & $\begin{array}{r}50 \\
1,114\end{array}$ \\
\hline & $\mathrm{RH}$ & 3,710 & 30.3 & 140.2 & $\begin{array}{r}300 \\
2,270\end{array}$ & $\begin{array}{r}80 \\
600\end{array}$ & $\begin{array}{r}133 \\
44\end{array}$ \\
\hline $\begin{array}{l}\text { Fluorinator } \\
\text { solids }\end{array}$ & $\mathrm{RH}$ & 30,970 & 17.5 & 19.3 & 210 & 55 & 93 \\
\hline \multirow{2}{*}{$\begin{array}{r}\text { GPT-SAC } \\
\text { waste }\end{array}$} & $\mathrm{CH}$ & 11,340 & 104 & 117.3 & 210 & 55 & 540 \\
\hline & $\mathrm{RH}$ & 7,080 & 70.3 & $125 . ?$ & $\begin{array}{r}210 \\
2,270\end{array}$ & $\begin{array}{r}55 \\
600 \\
\end{array}$ & $\begin{array}{r}198 \\
37 \\
\end{array}$ \\
\hline \multirow[t]{2}{*}{ Total containers } & $\mathrm{CH}$ & & & & & $\begin{array}{r}55 \\
80 \\
600\end{array}$ & $\begin{array}{r}660 \\
1,114 \\
4\end{array}$ \\
\hline & $\mathrm{RH}$ & & & & & $\begin{array}{r}55 \\
80 \\
600\end{array}$ & $\begin{array}{l}291 \\
133 \\
385\end{array}$ \\
\hline
\end{tabular}

(a) Values are shown in more significant figures than the accuracy of the data to maintain consistency of calculations.

(b) 657.9 containers/yr of $200-L$ HLW containers are not shown.

estimate the new dose rate range of the compacted waste. It was assumed that surface dose rate increases Tinearly with waste concentration, that it is a weak function of increased canister size, and that compaction provides negligible additional self-shielding. 
The process and equipment flow diagram for this option is shown in Figure 7.3. TRUW is first sorted and separated into CH TRUW and RH TRIJW, and these streams are then sorted by size. The large pieces of failed equipment, filters, and GPT-SAC waste are segregated, size reduced, and placed into 160-gal canisters with the smaller pieces of these wastes. This waste and the hulls and hardware are compacted in campaigns of CH or RH waste in a single incan compactor. A lid is sealed onto the canister after it is filled. All sealed canisters are inspected, assayed, certified, and labeled prior to being transferred to surge storage. Process steps prior to and following those shown in Figure 7.3 are shown in Figure 7.1 .

The treated and packaged weights and volumes and canister information for this option are given in Table 7.3 (based on a reprocessing rate of 1,500 $\mathrm{MTU} / \mathrm{yr}$ ). See Appendix $B$ for discussion of the derivation of these values. This option reduces the waste volume (based on the packaged volume in Option 1) by a factor of about 4 .

\subsection{OPTION 3 - MINIMUM NUMBER OF PROCESSES AND PFODUCTS (cementing)}

In this option, all the wastes (with size reduction or shredding for some wastes) are immobilized in cement and packaged at 90 vol\% waste loading. Figure 7.4 depicts the process and equipment flow diagram. Process steps prior to and following those shown in Figure 7.4 are given in Figure 7.1 .

The hulls and hardware are removed from their original (stainless steel) 600-gal containers, mixed with cement grout, and then poured back into carbon steel 600-gal containers. The cement grout incresses the hulls and hardware volume by an estimated $10 \mathrm{vol} \%$. The failed equipment is size reduced as necessary, and then premixed cement grout is poured over it in a carbon steel container of the same size as the original stainless steel container. The cement is assumed to fill the existing voids in the failed equipment containers with no increase in packaged waste volume. One RH cement mixer is dedicated to cementing the hulls, hardware, and failed equipmerit. The cement is also assumed to reduce the surface dose rate of the cortainers by a factor of 4 , thus converting some of the failed equipment from RH to $\mathrm{CH}$ after cementing. 


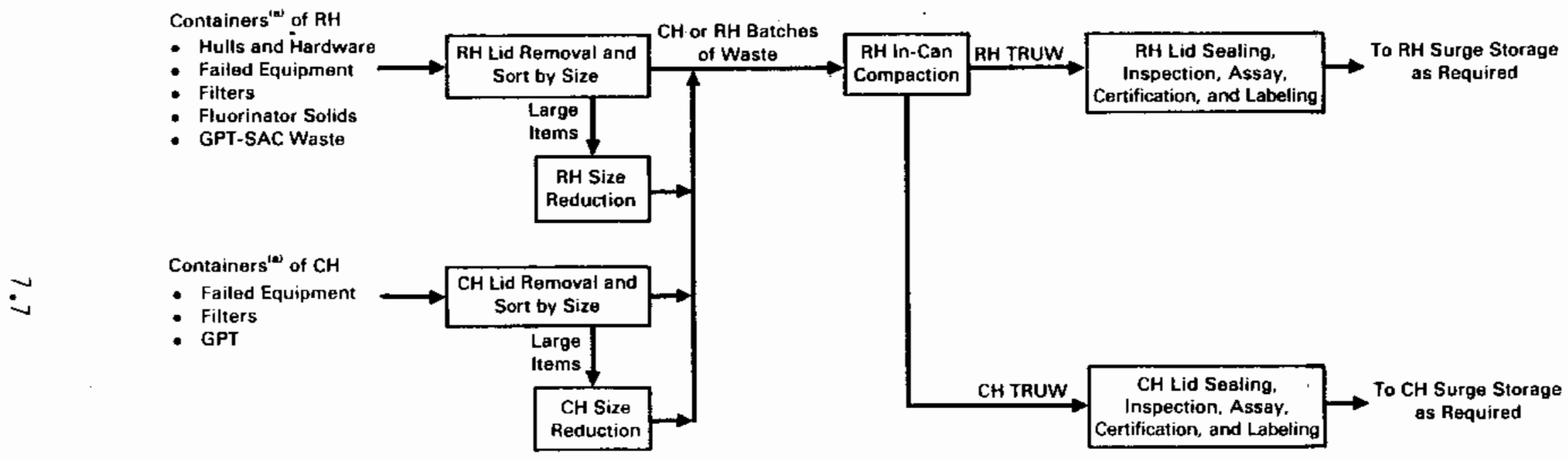

FIGURE 7.3. Process and Equipment Flow Diagram for Option 2 - Mi nimum Treatment(b)

(a) These containers hold the TRUW collected and packaged at the reprocessing facility that has been inspected and assayed, as depicted in Figure 7.1.

(b) This is the flow diagram reoresenting the minimum treatment option for the block titled "TRUW Treatment" in Figure 7.1. Process steps prior to and following the above process steos are also depicted there. 
TABLE 7.3. Weights, Volumes, and Containers of Treated TRUW from Option 2 - Minimum Treatment

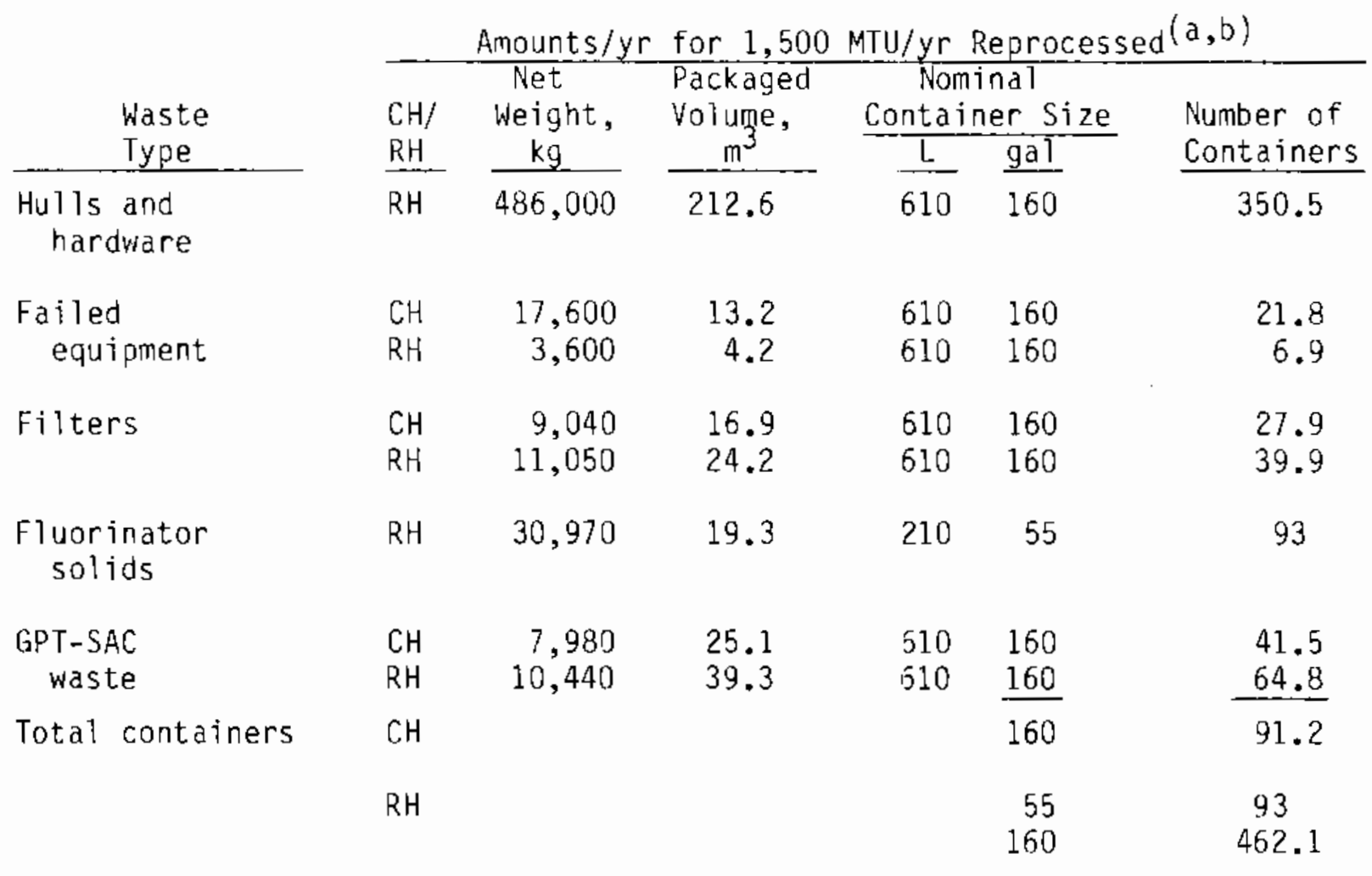

(a) Values are shown in more significant figures than the accuracy of the data to maintain consistency of the calculations.

(b) 657.9 containers/yr of $200-\mathrm{L}$ HLW containers are not shown.

The filters and GPT-SAC wastes are shredded in the appropriate RH or CH shredder. $\mathrm{RH}$ and $\mathrm{CH}$ batches of shredded waste are then mixed with the fluorinator solids and cement in an RH in-drum cementation facility. A key assumption that a maximum of $40 \mathrm{~kg}$ of "soft" material (cellulose, plastic and rubber, filter media) and $60 \mathrm{~kg}$ of "hard" material can be included in the cement formulation is taken from Schneider and Ledebrink (1983). The final reference cement formulation $(60 \mathrm{~kg}$ of hard material and $40 \mathrm{~kg}$ of soft material, plus cement and water) yields $0.20 \mathrm{~m}^{3}$ of cemented waste. (The amount of combustibles in this cement formulation is within the limits of the WIPP criteria, although WIPP criteria are not necessarily the same as those for commercial TRUW; see Table 4.1.) Aluminum in the filters can cause problems 


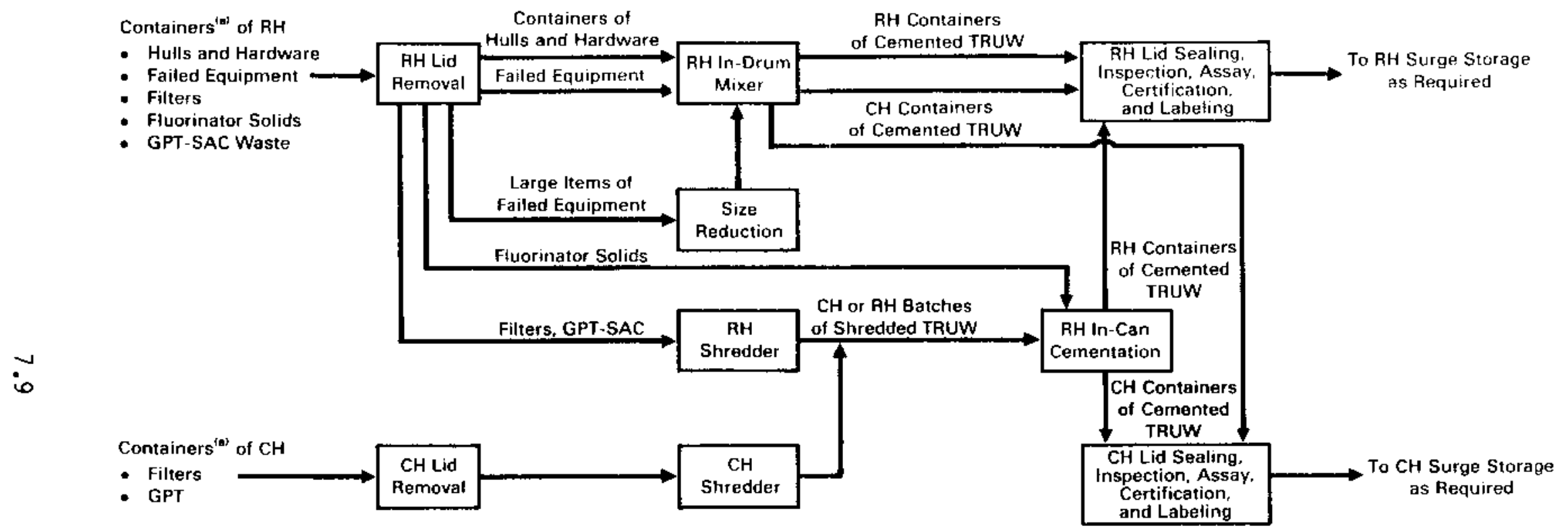

FIGURE 7.4. Process and Equipment Flow Diagram for Option 3 - Mi nimum Number of Processes and Products $(b)$

(a) These containers hold the TRUW collected and packaged at the reprocessing facility that has been inspected and assayed, as depicted in Figure 7.1 .

(b) This is the flow diagram representing 0ption 3 for the block titled "TRUW Ireatment" in Figure 7.1. Process steps prior to and following the above process steps are also depicted there. 
because it can react with the alkaline cement to form aluminum hydroxide and produce hydrogen gas. Because there is less void space to fill with cement in the shredded filters and GPT-SAC waste than in the failed equipment, it was assumed that cementation would provide more shielding for the filters and GPTSAC waste than for the failed equipment. Therefore, the cementing is assumed to reduce the surface dose rate of the filters and GPT-SAC waste by a factor of 2. The cemented filters are packaged in 55-gal drums.

The fairly high gamma content of the fluorinator solids will cause some of the $\mathrm{CH}$ filters and $\mathrm{CH}$ GPT to become RH after heing cemented with the fluorinator solids; this is accounted for in the surface dose rate estimate. The cemented fluorinator solids are packaged in 55-gal drums.

The net weight and packaged volumes of waste and canister information for Option 3 are given in Table 7.4. This option reduces the waste volume (based on the packaged volume in Option 1) hy a factor of about 1.1 .

TABLE 7.4. Weights, Volumes, and Containers of Treated TRIJW from nption 3 Minimum Number of Processes and Products

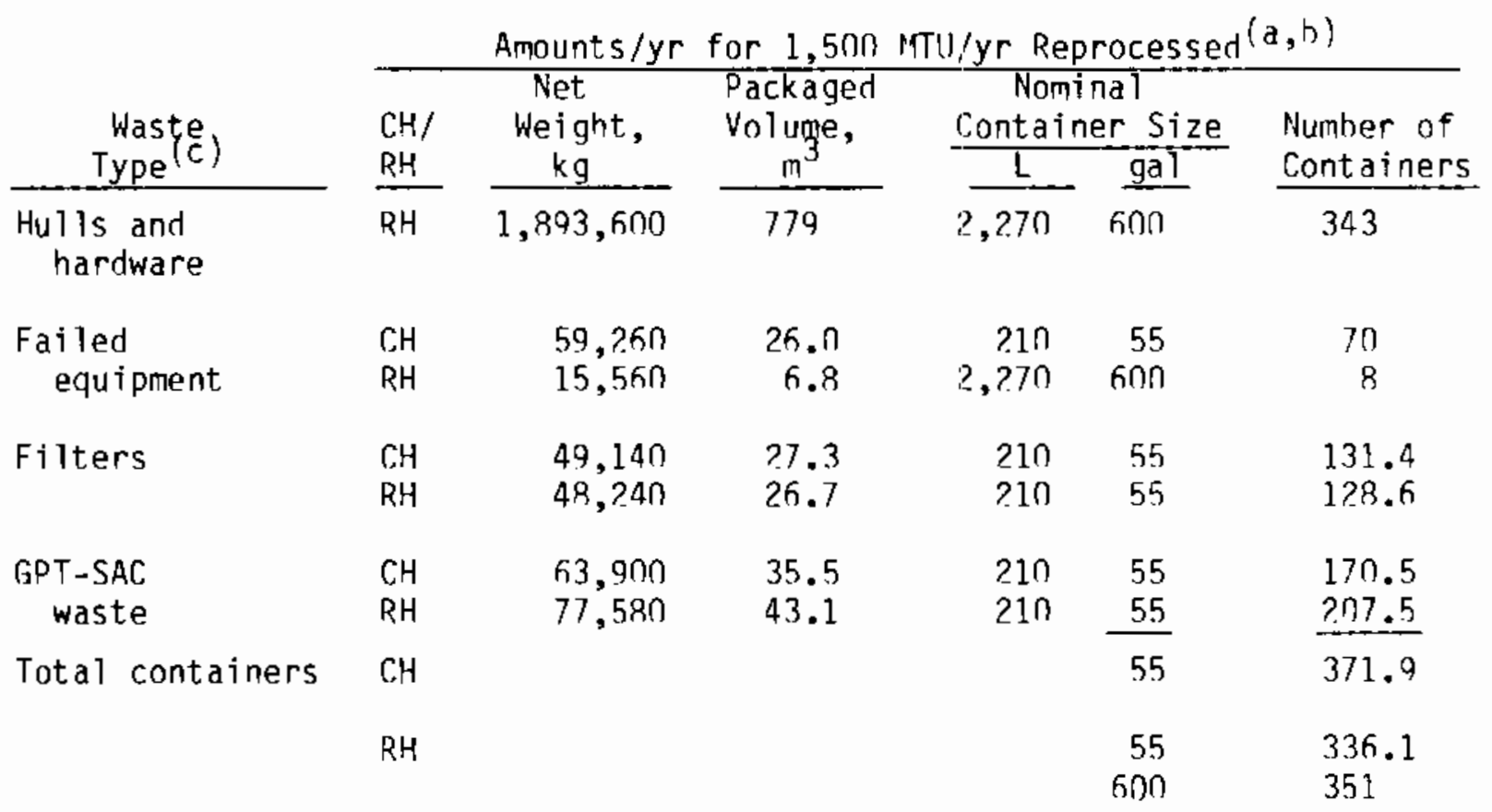

(a) Values are shown in more significant figures than the accuracy of the data to maintain consistency of the calculations.

(b) 657.9 containers/yr of 200-L HLW containers are not shown.

(c) Fluorinator solids are included in Filters and GPT-SAC baste totals. 


\subsection{OPTION 4 - MAXIMUM VOLUME REDUCTION WITHOUT DECONTAMINATION (mE1ting)}

High volume reduction factors are attained by burning the combustibles (excluding plastic and rubber), melting the metals and incineration residues, and hot pressing the plastic and rubber. All the treated waste is packaged at 90 vol\% loading in 160-gai canisters. Process steps prior to and following those in Figure 7.5 are given in Figure 7.1 .

After prior size reduction of some of the failed equipment and fuel assembly hardware, these two waste types are melted in $\mathrm{CH}$ or $\mathrm{RH}$ batches in a single RH vacuum induction melter (Montgomery and Nesbitt 1983) to 90\% of theoretical density.

The filters are shredded in either a $\mathrm{CH}$ or RH shredder and incinerated in an RH incinerator, resulting in an RH mixture of ash, media, and metals. The metals are then removed and combined with the failed equipment for melting as $\mathrm{RH}$ and $\mathrm{CH}$. The ash, filter media, and concentrated scrubber solution residues are melted in the $\mathrm{RH}$ melter.

It is assumed that the $\mathrm{CH} / \mathrm{RH}$ category of the metal HEPA filter frames dnes not change due to processing, since the melting crucible will be periodically changed and the $\mathrm{CH}$ melting can be done in campaigns, resulting in littie crosscontamination. Other streams may change from $\mathrm{CH}$ to $\mathrm{RH}$ due to concentration by melting.

The GPT-SAC waste is sorted into metals, plastic and rubber, and cellulose (i.e., paper, rags). The metals are melted with the failed equipment in $\mathrm{CH}$ and RH campaigns. The cellulose is incinerated with the filters previously mentioned, and the ash and scrubber residues from this incineration are melted as RH waste. To avoid large quantities of chlorine in the scrubber solution (from incineration of PVC plastics), the $\mathrm{CH}$ or RH batches of plastic and rubber are pressed in collapsible cans in an RH hot press. The compressed cans are then placed in the final container. Remote handled batches of fluorinator solids are melted to $90 \%$ of their theoretical density.

The packaged and unpackaged weights and volumes and container information for this option are given in Table 7.5. This option reduces the oriyinal volume of waste (based on packajed volume of untreated waste) hy a factor uf 12.5 . 


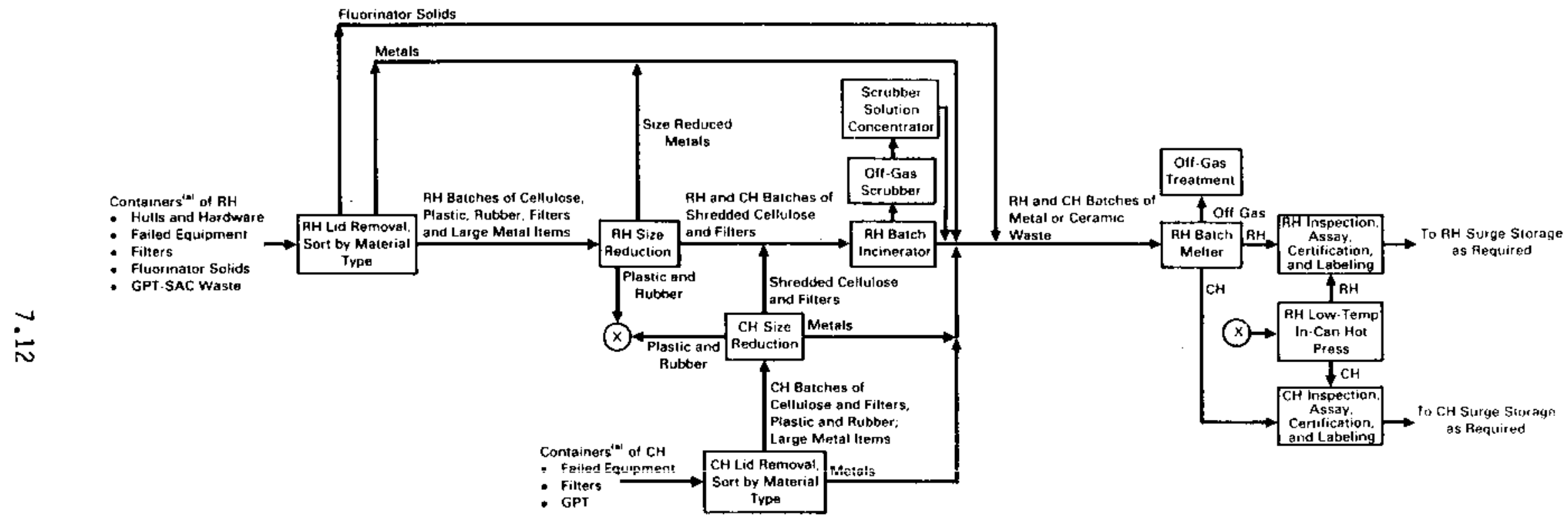
FIGURE 7.5. Equipment and Process Flow Diagram for Option 4 - Maximum Volume Reduction
Without Decontamination

(a) These containers hold the IRUW collected and packaged at the reprocessing facility that has been inspected and assayed, as depicted in Figure 7.1 .

(b) This is the flow diagram representing Option 4 for the block titled "TRUW Treatment" in Figure 7.1. Process steps prior to and following the above process steps are also depicted there. 
TABLE 7.5. Weights, Volumes, and Containers of Treated TRUW from Option 4 Maximum Volume Reduction Without Decontamination

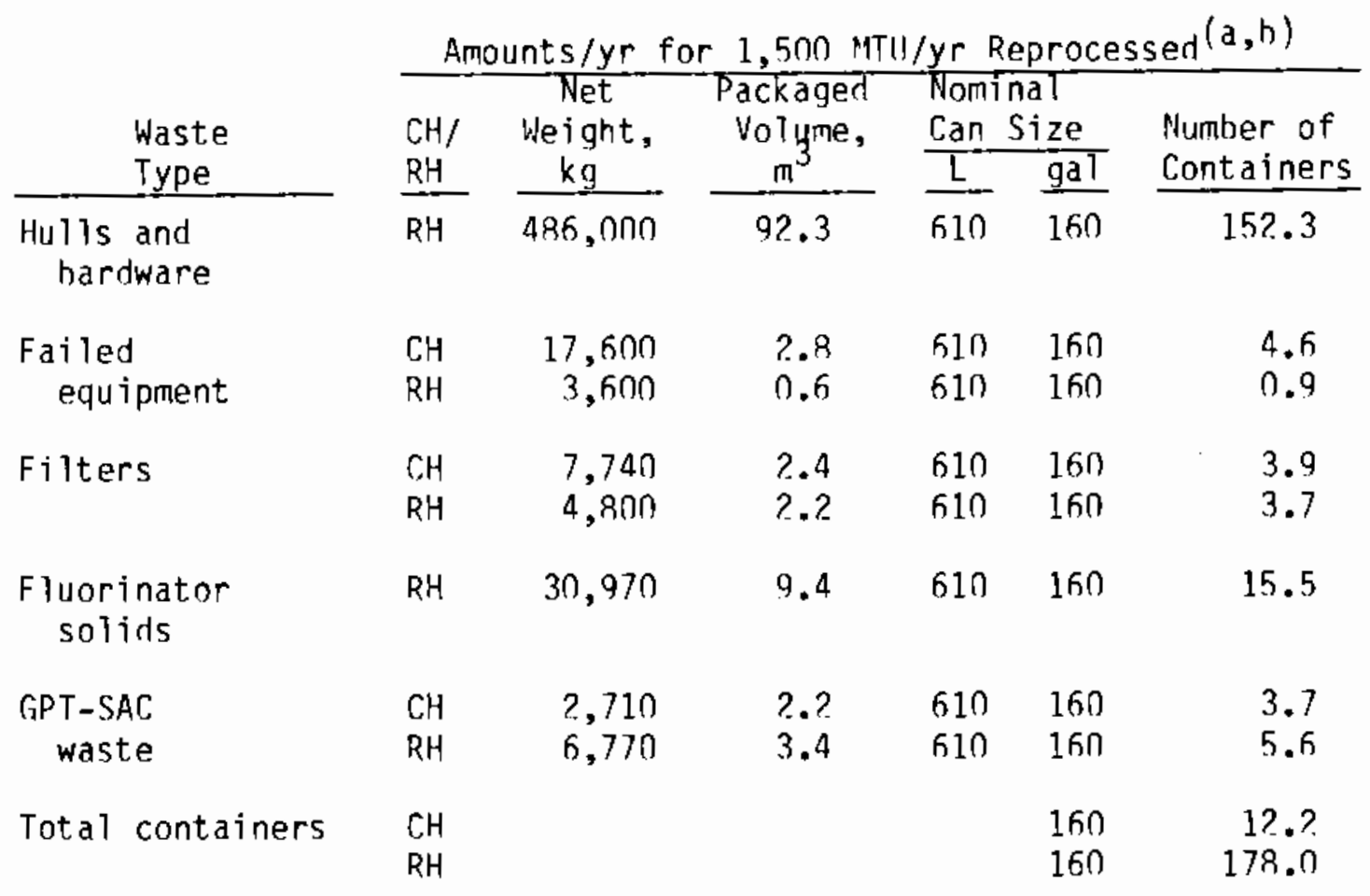

(a) Values are shown in more significant figures than the accuracy of the data to maintain consistency of the calculations.

(b) 657.9 containers/yr of $200-\mathrm{L}$ HLW containers are not shown.

\subsection{OPTION 5 - MAXIMUM VOLUME REDIICTION WITH DECONTAMINATION}

In this option, the decontaminable metal, plastic, and rubher are decontaminated, and the nondecontaminable metals are compacted. The cellulose and filters are incinerated, and following incineration, the metal filter frames are removed and decontaminated with the failed equipment. The residues from the incineration are vitrified with the HLW. The process and equipment flow diagram is given in Figure 7.6, and process steps prior to and following those in Figure 7.6 are shown in Figure 7.1 .

The hulls are cryogenically cooled so that they can he cracked to break open and size reduce the cylindrical hull pieces, and then they are decontaminated in a device called a centrifugal barrel. Two suboptions are considered for treating the resulting decontamination slurry, assumed to contain zirconium, zirconium dioxide, and aluminum oxide. In Suhoption 5A, the 


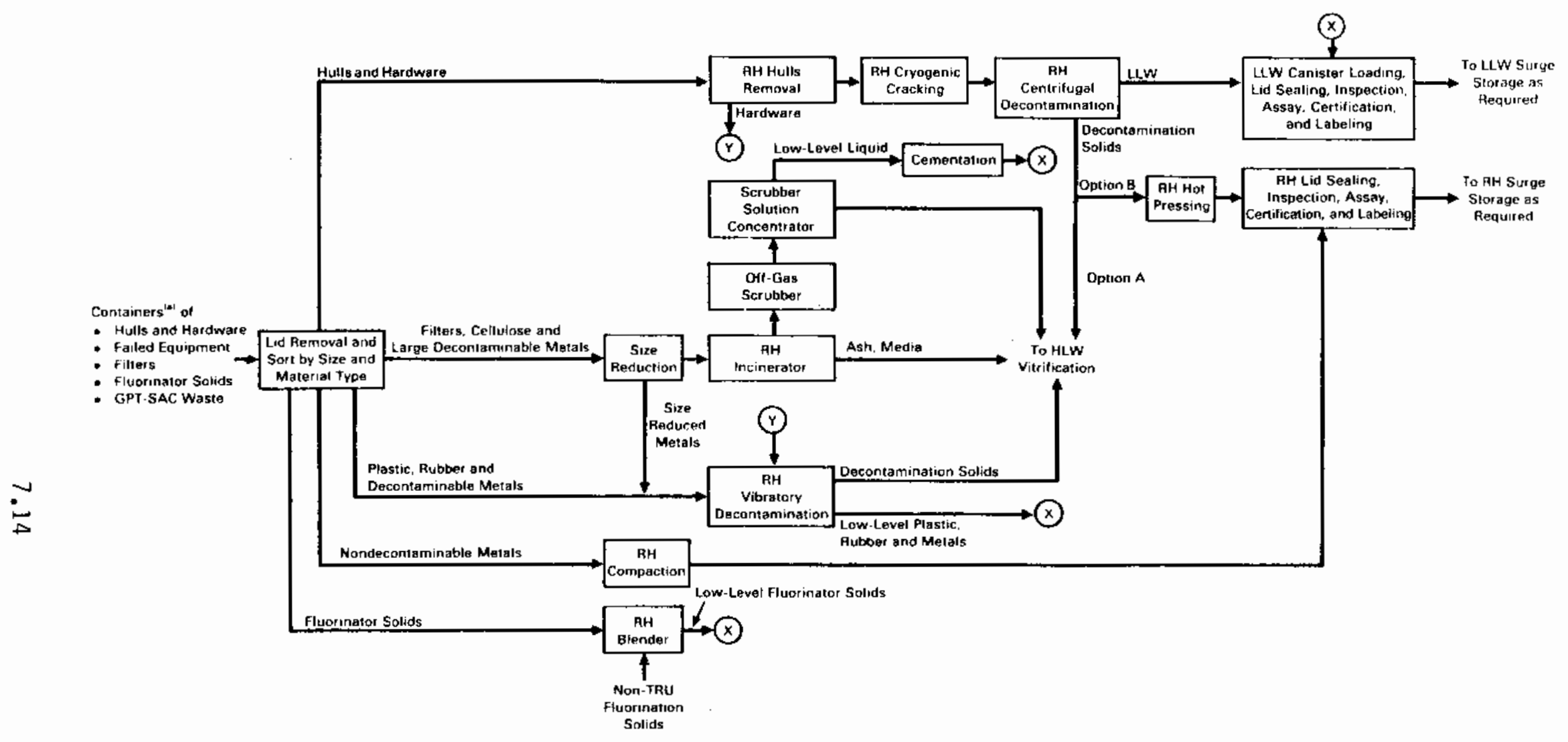

FIGURE 7.6. Process and Equipment Elow Diagram for Option 5 - Maximum Volume Reduction

(a) These containers hold the TRUW collected and packaged at the reprocessing facility that has been inspected and assayed, as depicted in Figure 7.1.

(b) This is the flow diagram representing Option 5 for the block titled "TRUW Treatment" in Figure 7.1. Process steps prior to and following the above process steps are also depicted there. 
zirconium, zirconium dioxide, and aluminum oxide are combined with the HLW glass at 20 wt $\%$ equivalent waste loading. The diameter of the HLW canisters from the reprocessing operation is increased so that the additional HLW from the TRUW treatment can be accommodated in the same number of HLW containers. This was done because canister contents can be limited during storage, transportation, and disposal by total heat generation rate, which is not significantly changed by the addition of the TRIJW. In Suhoption 5R the decontamination slurry is hot pressed to a density of $3,510 \mathrm{~kg} / \mathrm{m}^{3}$ (9n\% of theoretical density) to hecome RH TRUW. A preoxidation step to convert zirconium to zirconium dioxide may he required.

The hardware from the spent fuel, decontaminable failed equipment and metallic GPT-SAC waste, and plastic and rubber are decontaminated by vibratory finishing. The decontamination slurry (consisting of metal, plastic, and rubber fines), incineration ash, and sodium hydroxide (from the incinerator off-gas scrubher) are vitrified at 33 wt $\%$ loading with the HLW glass.

The combustible parts of the filters and cellulose GPT-SAC waste are incinerated. The metal in the filters is removed and decontaminated by vihratory finishing with the metals mentioned above. The ash and scrubber residues are loaded into the $H L W$ glass at $33 \mathrm{wt} \%$ and the filter media at $100 \mathrm{wt} \%$. The small quantity of chlorine in the plastic and rubher fines from the GPT-SAC, incineration could present volatilization and off-gas difficulties when treated by vitrification.

The TRII fluorinator solids are reduced to LLW by mixing them with the other non-TRU fluorinator solids. This strategy will require good radiological characterization of each batch of waste.

The packaged weights and volumes and container information for the decontamination option based on 1,500 MTU are given in Table 7.6 for suboption $5 \mathrm{~A}$ and in Table 7.7 for Suboption $5 B$. 
TARLE 7.6. Weights, Volumes, and Containers of Treated TRUW from Suboption 5A - Maximum Volume Reduction with necontamination (vitrification with HLW glass) (a)

\begin{tabular}{|c|c|c|c|c|c|c|}
\hline $\begin{array}{l}\text { Waste } \\
\text { Type }\end{array}$ & $\begin{array}{l}\overline{\mathrm{LLW} / \mathrm{HLW}} \\
\mathrm{CH} \text { TRUW } \\
\mathrm{RH} \text { TRIJW }\end{array}$ & $\begin{array}{l}\text { Amount/yr } \\
\text { Wet } \\
\text { Weight, } \\
\mathrm{kg}\end{array}$ & $\begin{array}{c}\text { for } 1,500 \\
\text { Packaged } \\
\text { Volume, } \\
\mathrm{m}^{3}\end{array}$ & $\begin{array}{r}\frac{\text { No/yr }}{\text { Non }} \\
\text { Contai } \\
\mathrm{L} \\
\end{array}$ & $\begin{array}{l}\text { orocesse } \\
\text { mal } \\
\text { er Size } \\
\text { gal }\end{array}$ & $\begin{array}{l}\text { Number of } \\
\text { Containers } \\
\end{array}$ \\
\hline Hulls & $\begin{array}{l}\text { LI_W } \\
\text { HLW }\end{array}$ & $\begin{array}{l}373,380 \\
183,250\end{array}$ & $\begin{array}{r}305.0 \\
75.4\end{array}$ & $\begin{array}{l}610 \\
320\end{array}$ & $\begin{array}{r}160 \\
85\end{array}$ & $\begin{array}{r}503.3 \\
(\text { b) }\end{array}$ \\
\hline Hardware & $\begin{array}{l}\text { LLW } \\
\text { HLW }\end{array}$ & $\begin{array}{r}84,350 \\
730\end{array}$ & $\begin{array}{r}93.7 \\
0.3\end{array}$ & $\begin{array}{l}610 \\
320\end{array}$ & $\begin{array}{r}160 \\
85\end{array}$ & $\begin{array}{r}154.6 \\
\text { (b) }\end{array}$ \\
\hline $\begin{array}{l}\text { Failed } \\
\quad \text { equipment }\end{array}$ & $\begin{array}{l}\text { LLW } \\
\text { HLW } \\
\text { CH TRIJW } \\
\text { RH TRIJW }\end{array}$ & $\begin{array}{r}14,810 \\
129 \\
4,831 \\
1,529\end{array}$ & $\begin{array}{c}10.1 \\
0.05 \\
4.0 \\
1.3\end{array}$ & $\begin{array}{l}610 \\
320 \\
610 \\
610\end{array}$ & $\begin{array}{r}160 \\
85 \\
160 \\
160\end{array}$ & $\begin{array}{r}16.7 \\
N / A \\
6.5 \\
2.1\end{array}$ \\
\hline Filters & $\begin{array}{l}\text { LLW } \\
\text { HLW }\end{array}$ & $\begin{array}{r}10,340 \\
8,450\end{array}$ & $\begin{array}{r}21.7 \\
3.2\end{array}$ & $\begin{array}{l}610 \\
320\end{array}$ & $\begin{array}{r}160 \\
85\end{array}$ & $\begin{array}{r}35.8 \\
\text { (b) }\end{array}$ \\
\hline $\begin{array}{l}\text { Fluorinator } \\
\text { solids }\end{array}$ & LLW & -- & 20.6 & 610 & 160 & 32.0 \\
\hline $\begin{array}{r}\text { GPT-SAC } \\
\text { waste }\end{array}$ & $\begin{array}{l}\text { LLW } \\
\text { HLW } \\
\text { CH TRUW } \\
\text { RH TRIJW }\end{array}$ & $\begin{array}{r}7,460 \\
760 \\
506 \\
19,550 \\
780\end{array}$ & $\begin{array}{r}78.9 \\
0.3 \\
0.4 \\
11.9 \\
0.6 \\
\end{array}$ & $\begin{array}{l}610 \\
320 \\
610 \\
210 \\
610 \\
\end{array}$ & $\begin{array}{r}160 \\
85 \\
160 \\
55 \\
160\end{array}$ & $\begin{array}{r}130.2 \\
(\mathrm{~b}) \\
0.7 \\
57.4 \\
1.1 \\
\end{array}$ \\
\hline $\begin{array}{l}\text { Total containers } \\
\text { and HLW volume }\end{array}$ & $\begin{array}{l}\text { LLW } \\
\text { HLW } \\
\text { CH TRUW } \\
\text { RH TRIJW }\end{array}$ & & 79.3 & 160 & $\begin{array}{r}160 \\
85 \\
160 \\
55 \\
3.2\end{array}$ & $\begin{array}{r}874.6 \\
(b) \\
7.2 \\
57.4\end{array}$ \\
\hline
\end{tabular}

(a) Values are shown in more significant figures than the accuracy of the data to maintain consistency of the calculations.

(b) The HLW generated resulting from TRUW processing is combined with the original $\mathrm{HLW}$ generated from the $1,500 M \mathrm{MU} / \mathrm{yr}$ reprocessing. The size of the original HLW canister is increased (from 12.3 in. i.d. by 120 in. long to $15.5 \mathrm{in.}$ i.d. by $120 \mathrm{in}$. long) to accommodate this additional waste. Therefore the original number of HLW canisters (657.9) does not change. 
TABLE 7.7. Weights, Volumes, and Containers of Treated TRUW from Suboption 5B - Maximum Volume Reduction with Decontamination (hot pressing with solids to become RH TRUW) (a)

\begin{tabular}{|c|c|c|c|c|c|c|}
\hline $\begin{array}{l}\text { Waste } \\
\text { Type }\end{array}$ & $\begin{array}{l}\text { LLW/HLW } \\
\text { CH TRIN } \\
\text { RH TRUW } \\
\end{array}$ & $\begin{array}{l}\text { rounts /yr } \\
\text { Wet } \\
\text { Weight, } \\
\text { kg }\end{array}$ & $\begin{array}{c}\text { for } 1,5 m 0 \\
\text { Packaged } \\
\text { Vol uge, } \\
\mathrm{m}^{3} \\
\end{array}$ & $\begin{array}{r}\mathrm{TU} / \mathrm{yr} \\
\mathrm{No} \\
\text { Conta } \\
\frac{\mathrm{L}}{\mathrm{L}}\end{array}$ & $\begin{array}{l}\text { process } \\
\text { inal } \\
\text { ga? Size }\end{array}$ & $\begin{array}{l}\text { Number of } \\
\text { Containers }\end{array}$ \\
\hline Hulls & $\begin{array}{l}\text { LLW } \\
\text { RH TRUW }\end{array}$ & $\begin{array}{r}373,380 \\
33,033\end{array}$ & $\begin{array}{l}305 \\
9.2\end{array}$ & $\begin{array}{l}610 \\
610\end{array}$ & $\begin{array}{l}160 \\
160\end{array}$ & $\begin{array}{r}503.3 \\
15.2\end{array}$ \\
\hline Hardware & $\begin{array}{l}\text { LLW } \\
\text { HLW }\end{array}$ & $\begin{array}{r}84,35 n \\
730\end{array}$ & $\begin{array}{r}93.7 \\
0.3\end{array}$ & $\begin{array}{l}610 \\
200\end{array}$ & $\begin{array}{r}160 \\
53\end{array}$ & $154.6)$ \\
\hline $\begin{array}{l}\text { Failed } \\
\text { equipment }\end{array}$ & $\begin{array}{l}\text { LLW } \\
\text { HLW } \\
\text { CH TRIJW } \\
\text { RH TRIJW }\end{array}$ & $\begin{array}{r}14,810 \\
129 \\
4,831 \\
1,529\end{array}$ & $\begin{array}{c}10.1 \\
0.05 \\
4.0 \\
1.3\end{array}$ & $\begin{array}{l}610 \\
200 \\
610 \\
610\end{array}$ & $\begin{array}{r}160 \\
53 \\
160 \\
160\end{array}$ & $\begin{array}{c}16.5 \\
5.5 \\
2.1\end{array}$ \\
\hline Filters & $\begin{array}{l}\text { LLW } \\
\text { HLW }\end{array}$ & $\begin{array}{r}10,340 \\
8,450\end{array}$ & $\begin{array}{r}21.7 \\
3.2\end{array}$ & $\begin{array}{l}610 \\
200\end{array}$ & $\begin{array}{r}160 \\
53\end{array}$ & 35.8 \\
\hline $\begin{array}{l}\text { Fluorinator } \\
\text { solids }\end{array}$ & LLW & 30,970 & 19.4 & 610 & 160 & 32.0 \\
\hline $\begin{array}{r}\text { SPT-SAC } \\
\text { waste }\end{array}$ & $\begin{array}{l}\text { LLW } \\
\text { HLW } \\
\text { CH TRUW } \\
\text { RH TRIJW }\end{array}$ & $\begin{array}{r}7,460 \\
760 \\
506 \\
19,550 \\
780\end{array}$ & $\begin{array}{r}78.9 \\
0.3 \\
0.4 \\
11.9 \\
0.5 \\
\end{array}$ & $\begin{array}{l}610 \\
200 \\
610 \\
? 10 \\
610\end{array}$ & $\begin{array}{r}160 \\
53 \\
160 \\
55 \\
160 \\
\end{array}$ & $\begin{array}{r}130.2 \\
0.7 \\
57.4 \\
1.1 \\
\end{array}$ \\
\hline $\begin{array}{l}\text { Total containers } \\
\text { and HLW volume }\end{array}$ & $\begin{array}{l}\text { LLW } \\
\text { HLW } \\
\text { CH TRUW } \\
\text { RH TRUW }\end{array}$ & & 3.8 & 160 & $\begin{array}{r}160 \\
53 \\
160 \\
55 \\
18.4\end{array}$ & $\begin{array}{r}874.69 \\
7.2 \\
57.4\end{array}$ \\
\hline
\end{tabular}

(a) Values are shown in more significant figures than the accuracy of the data to maintain consistency of the calculations.

(b) The HLW generated resulting from TRUW processing is combined with the original $\mathrm{HLW}$ generated from the $1,50 \mathrm{n} M \mathrm{TU} / \mathrm{yr}$ reprocessing. It is assumed that the $3.8 \mathrm{~m}^{3}$ of $\mathrm{HLW}$ generated from the TRIJW processing can be added to the HLW from the reprocessing without increasing the number of canisters or requiring that the canister size $(12.3 \mathrm{in}$. i.t. $x 120 \mathrm{in.}$ long) be increased. 
7.6 OPTION 6 - NONCOMBUSTIBLE FORMS (melting arid cementing)

The noncombustible waste form option involves melting most of the metals, shredding and burning the filters and the combustible parts of GPT-SAC waste (the metals in the GPT-SAC waste are removed pricr to incineration and melted with the failed equipment), and cementing the ash and secondary wastes from incineration and fluorinator solids. This option is very similar to option 4; the major differences are that the filters are cemented following incineration, the fluorinator solids are cemented, the plastic and rubber from the GPT-SAC waste are incinerated with the cellulose, and the scrubber solution residues from incineration are cemented. The process and equipment flow diagram is given in Figure 7.7. Process steps prior to and following those in Figure 7.7 are shown in Figure 7.1 .

The hulis and hardware, failed equipment, and the metals from the GPT-SAC waste are melted in the same manner as the metals in option 4.

The filters and combustible GPT-SAC wastes are shredded in either a RH or $\mathrm{CH}$ shredder and are then incinerated in $\mathrm{CH}$ or $\mathrm{RH}$ satches in the same incinerator. $\mathrm{CH}$ and RH batches of ash, scrubber residues, media, and metal frames are cemented in their respective batches in a single RH in-drum mixer, using the same cement recipe as in option 3. The fluorinator solids are cemented at 30 wt\%, which results in LLW. The cemented waste is loaded at $90 \mathrm{vol} \%$. The packaged weights and volumes and container information for the noncombustible waste forms option are given in Table 7.8 .

\subsection{SUMMARY OF WASTE QUANTITIES}

Table 7.9 summarizes the initial and final volumes of packaged waste in each treatment option. Also included in this table are the volume reduction ratios, obtained by dividing the no treatment packaged volumes by the final packaged volumes in each treatment option.

In options 2, 4 and 6, volune reductions are achieved by concentrating the initial TRUW into a smaller volume by compaction, melting, or incineration and 


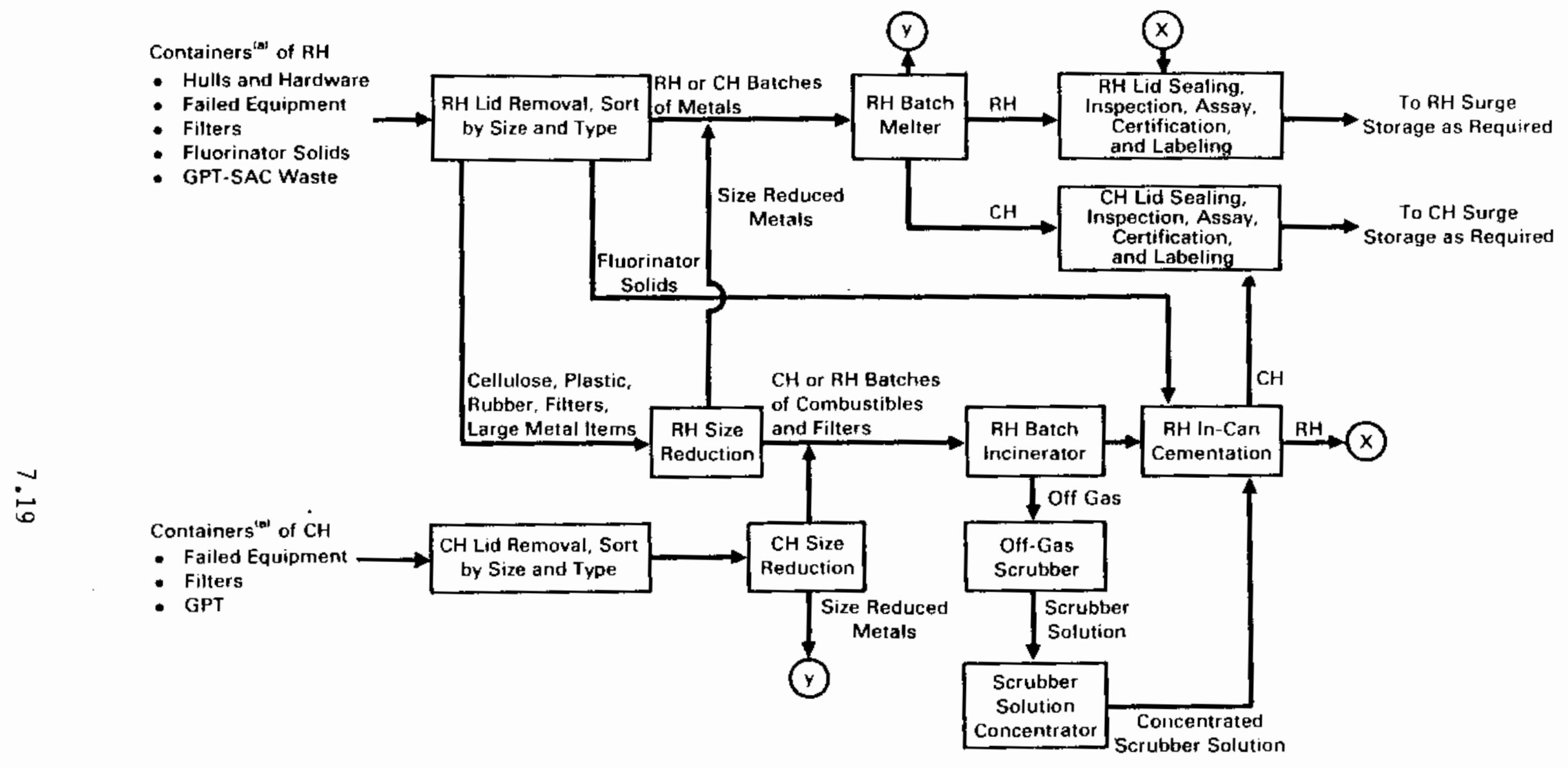

FIGURE 7.7. Process and Equipment Flow Diagram for Option 6 - Noncombustible Waste Forms(b)

(a) These containers hold the TRUW collected and packaged at the reprocessing facility that have been inspected and assayed, as depicted in Figure 7.1 .

(b) This is the flow diagram representing Option 6 for the block titled "TRUW Treatment" in Figure 7.1. Process steps prior to and following the above process steps are also depicted
there. 
TABLE 7.8. Weights, Volumes, and Containers of Treated TRUW

from 0ption 6 - Noncombustible Waste Forms

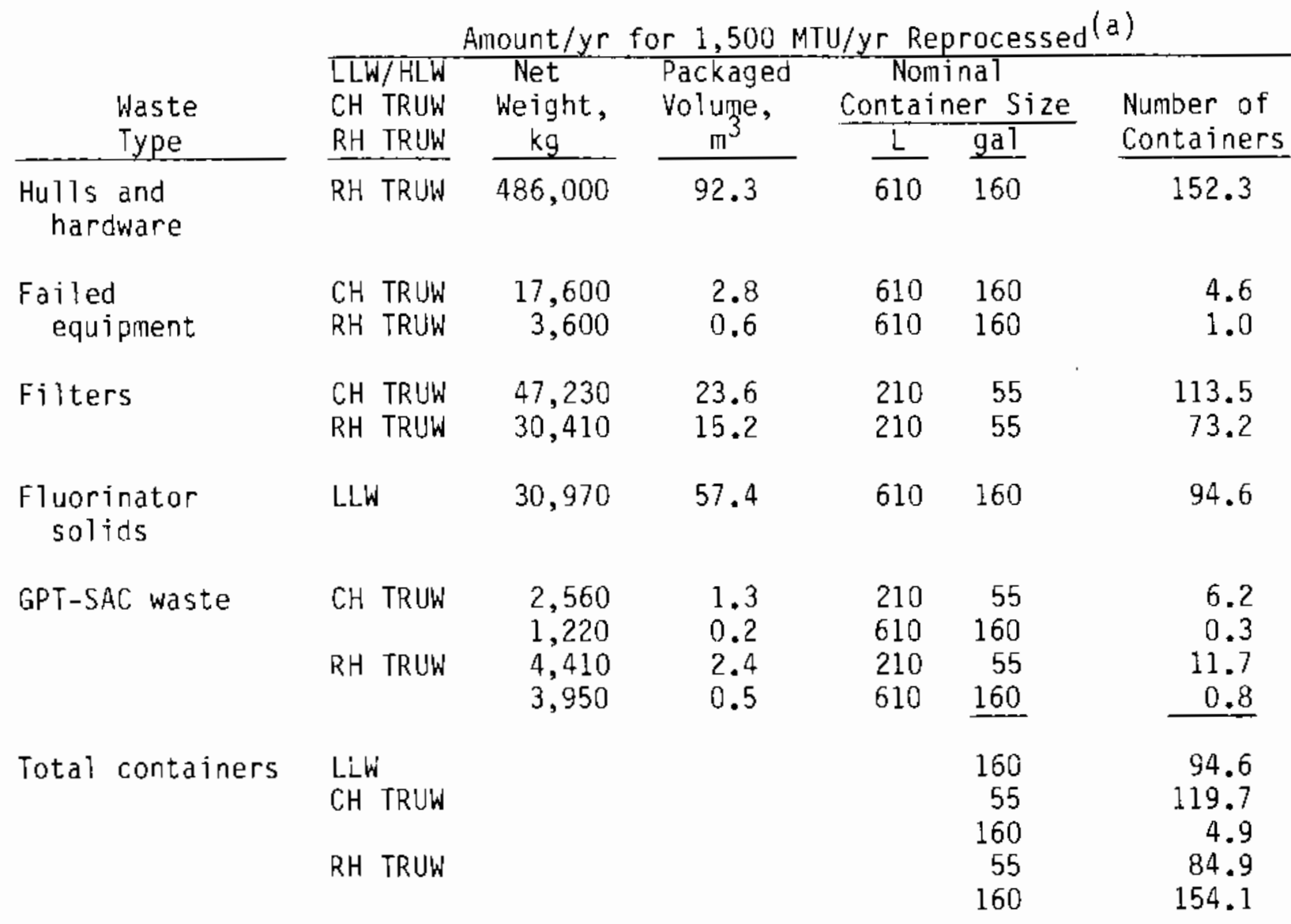

(a) Values are shown in more significant figures than the accuracy of the data to maintain consistency of the calculations.

(b) 657.9 containers/yr of 200-L HLW containers are not shown.

melting. This causes some of the wastes which are initially CH TRUW to become RH TRUW; this in turn causes the high volume reduction ratios for CH TRUW in options 2 and 4 . Therefore the CH TRUW is not only volume reduced, but the actual quantity of $\mathrm{CH}$ TRUW is also reduced.

In Option 6, cementing is also employed, which provides some shielding, so some of the RH TRUW becomes CH TRUW. Thus in 0ptions 3 and 6 , the volume reduction ratios for $\mathrm{CH}$ TRUW are not very high because some of the RH TRUW has been reclassified as $\mathrm{CH}$ TRUW. 


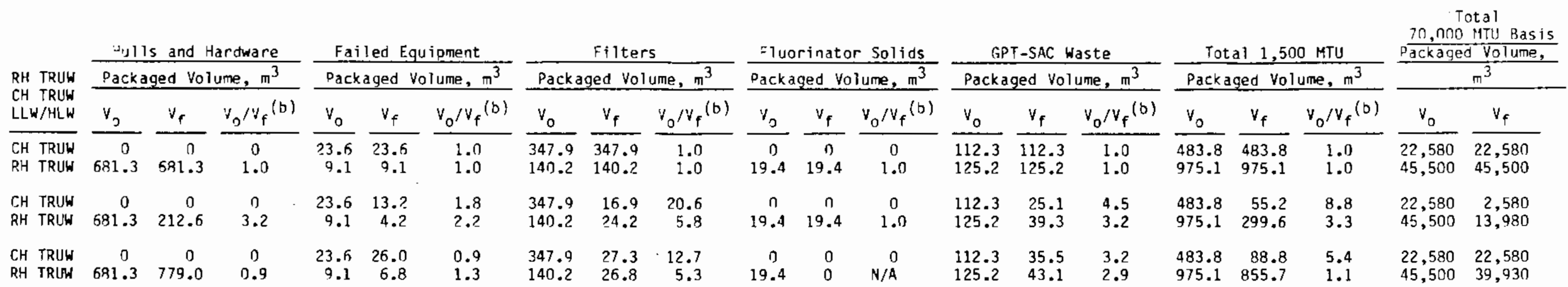

Dotion

2. Minimum treatnent $\begin{array}{cccc}\text { CH TRUW } & 0 & 0 & 0 \\ \text { RH TRUW } & 681.3 & 212.6 & 3.2\end{array}$

3. Minimum number of and products

4. Maximum volume reduction
without $\begin{array}{lcccrcrrrr}\text { CH TRUW } & 0 & 0 & 0 & 23.6 & 2.8 & 8.4 & 347.9 & 2.4 & 145 \\ \text { RH TRUW } & 681.3 & 92.3 & 7.4 & 9.1 & 0.6 & 15.0 & 140.2 & 2.2 & 64\end{array}$

5A. Maximum volume reduction with

CH TRUW

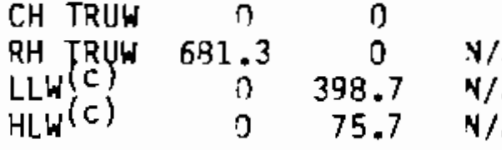

$$
\begin{array}{ccc}
23.6 & 4.0 & 5.9 \\
9.1 & 1.3 & 7.0 \\
0 & 10.1 & N / A \\
0 & 0.05 & N / A
\end{array}
$$

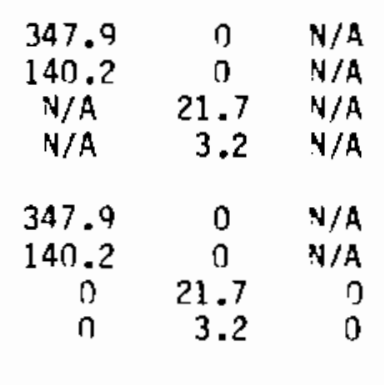

$\stackrel{n}{19.4} \quad \stackrel{0}{9.4} \quad 2.1$

$\begin{array}{lll}112.3 & 2.2 & 51 \\ 125.2 & 3.4 & 37\end{array}$

$\begin{array}{rrr}483.8 & 7.4 & 65.0 \\ 975.1 & 107.9 & 9.0\end{array}$

$\begin{array}{rr}22,580 & 340 \\ 45,500 & 5,040\end{array}$

58. Haximum volume
reduct ion with

$\begin{array}{lcccccc}\text { CH TRUW } & 0 & 0 & 0 & 23.5 & 4.0 & \text { N/A } \\ \text { RH TRUWW } & 631.3 & 9.2 & 74.0 & 9.1 & 1.3 & \text { N/A } \\ \text { LLWW (C) } & 0 & 398.7 & \text { N/A } & 0 & 10.1 & 0 \\ \text { HLW (C) } & 0 & 0.3 & \text { N/A } & 0 & 0.05 & 0\end{array}$

6. Noncombustible

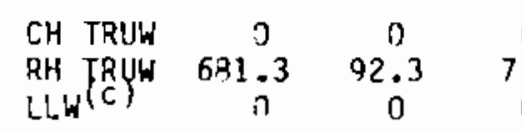
waste forms

(a) Values are shown in more significant figures than the accuracy of the data to maintain consistency of the calculations.

(b) $V_{o} / V_{f}$ is defined as initial packaged volume divided by the final packaged volume. If the final packaged volume is zero with a finite initial packaged volume, this implies that the waste type was converted to another waste form resulting in $v_{0} / 0$, or infinity. If the initial packaged volume is zero with a finite final volume, then a waste form was created, or $0 / V_{f}$. In both of these cases, "Nonapolicable" (N/A) is indicated under $V_{0} / v_{f}$. 

The volume reduction ratios in 0ption 5 do not describe the change in waste volume very effectively, since much of the original TRUW is not processed into another form of TRUW but instead is decontaminated to produce LLW and HLW (in Suboption 5A) or decontaminated to produce LLW and TRUW (in Suboption 5B). Thus the significant reduction in the quantity of TRUW in these subsections is somewhat misleading, since most of the TRUW is converted to HLW or LLW.

The greatest volume reduction ratios are attained in option 4 (volume reduction ratios are 66.0 for $\mathrm{CH}$ TRUW and 9.0 for RH TRUW and in Option 6 (volume reduction ratios are 17.3 for $\mathrm{CH}$ TRUW, 8.8 for RH TRUW, plus $57.3 \mathrm{~m}^{3}$ of LLW that cannot be included in the volume reduction ratio because there is no LLW in Option 1 with which to compare it).

Table 7.10 sumarizes the final number of containers holding treated TRUW, the increase in the number of cans of LLW, and the increase in volume of HLW.

\subsection{REFERENCES}

Darr, D. G. 1983. Waste Model Characteristics Study: Evaluation of Reprocessing Waste Estimates. D0E/3156/FR-01, Allied-General Nuclear Services, BarnwelT, South Carotina.

Montgomery, D. R. and J. F. Nesbitt. 1983. Review and Evaluation of Metallic TRU Nuclear Waste Consolidation Methods. PNL-4754, Pacific Northwest Laboratory, Richland, Washington.

Schneider, V. W., and F.W. Ledebrink. 1983. "Cementation of TRU-Wastes by a New Process, Properties of the Products." Presented at Second International Symposium on Ceramics in Nuclear Waste Managenent, Chicago, Illinois. 


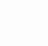

. 


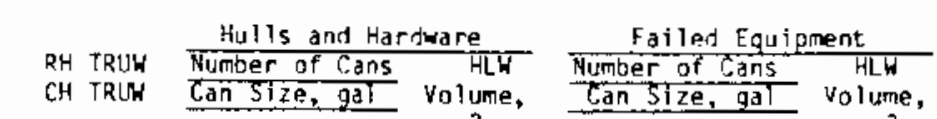

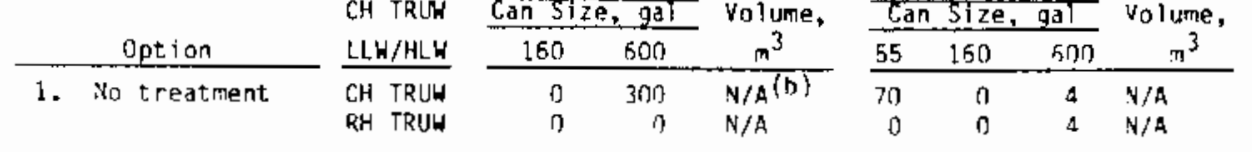

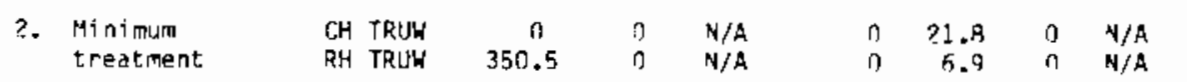

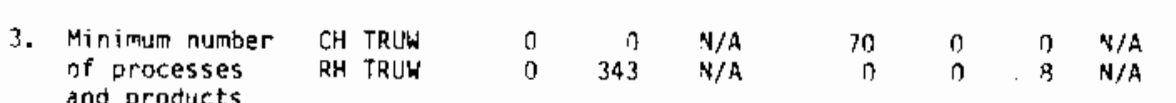

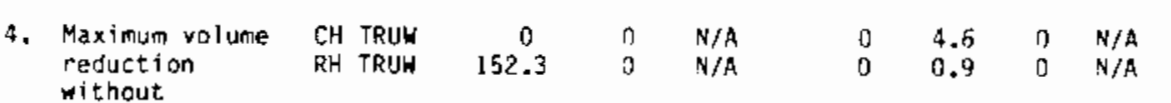
decontanination

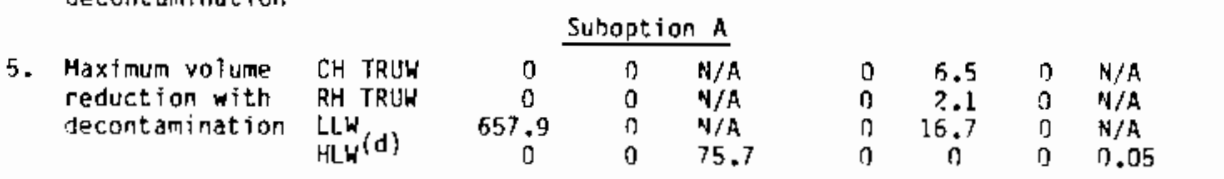

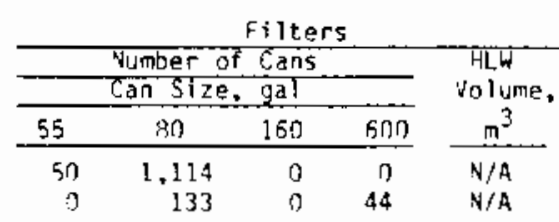

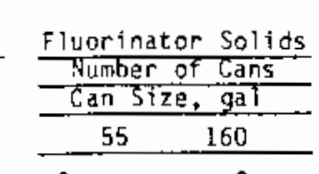

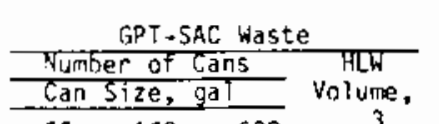

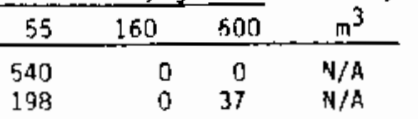

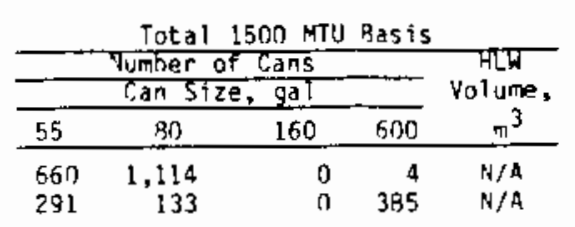

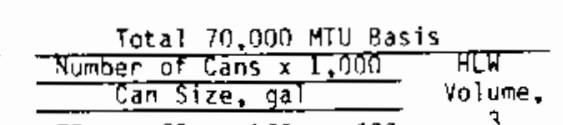

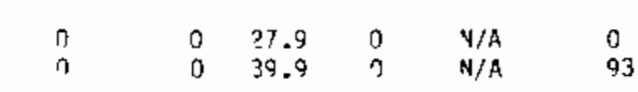
131.4
128.6

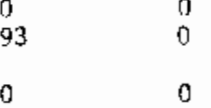

$\begin{array}{lllll}0 & 41.5 & 0 & \mathrm{~N} / \mathrm{A} \\ 0 & { }_{64.8} & 0 & & \\ \mathrm{~N} / \mathrm{A}\end{array}$

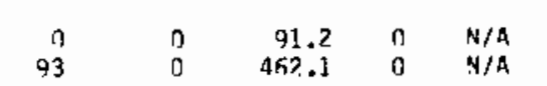

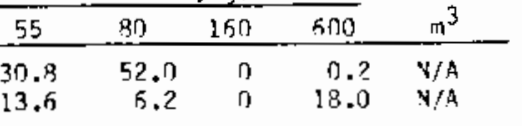

$0(c)$
$0(c)$

$\begin{array}{llll}0 & 3.9 & 0 & N / A \\ 1 & 3.7 & D & N / A \\ & & & \end{array}$

$\begin{array}{llll}170.5 & 0 & 0 & 0 \\ 207.5 & 0 & 0 & N / 4 \\ N / 4\end{array}$

371.9

15.5

$\begin{array}{llll}0 & 3.7 & 0 & \mathrm{~N} / \mathrm{A} \\ 0 & 5.6 & 0 & \mathrm{~N} / \mathrm{A}\end{array}$

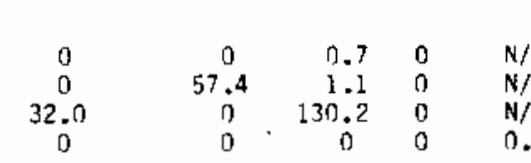

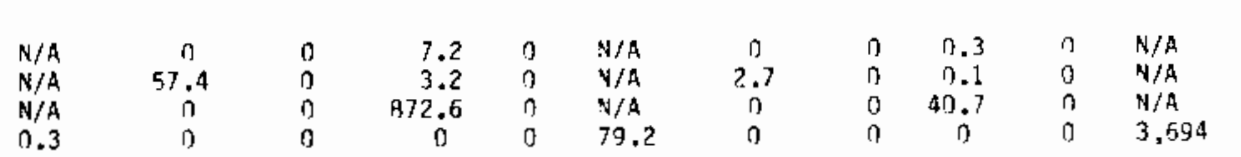

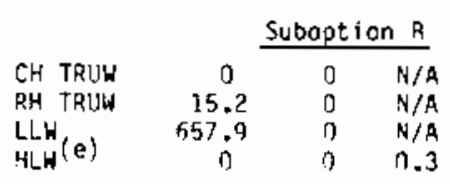

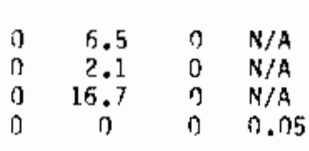

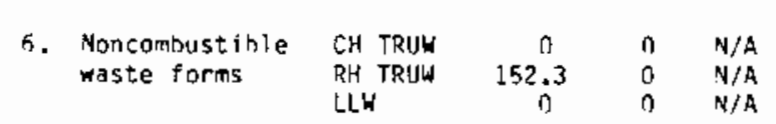

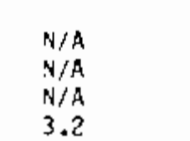

$N / A$
$N / A$
$N / A$
3.2

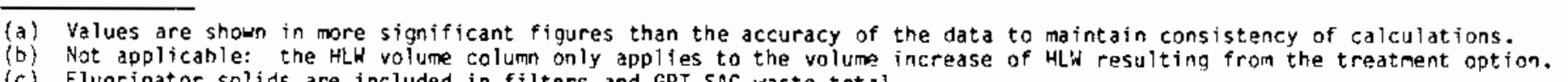

(c) Fluorinat or solids are included in filters and GPT-SAC waste total.

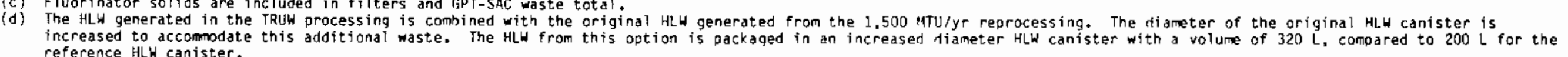

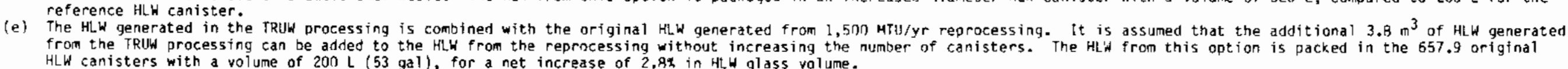

TABLE 7.10. Number of Canisters/Mrums Produced 



\subsection{COST CONSIDERATIONS}

High-spot cost estimates were performed for each TRUW treatment option. The costs were estimated for constructing and operating the TRUW treatment and associated service facility beyond what currently exists at the BNFP reprocessing plant, for transporting the treated waste to a disposal site, for the disposal of the treated TRUW and incremental HLW at a repository, and for the disposal of incremental LLW at a LLW disposal site. Costs for R\&D, selection and development of the repository, and decommissioning of the treatment facilities and the repository were not included. The costs presented are in mid-1983 dollars on an undiscounted basis. These estimates were used to evaluate the cost-effectiveness of the six TRUW treatment options.

This section describes the results of these cost analyses. Supporting data for the cost analyses are presented in Appendix 0 .

\subsection{COST OF TRUW TREATMENT FACILITIES}

The capital and operating costs were estimated for the TRUW treatment facilities for each strategy option studied. It was assumed that two commercial fuel reprocessing facilities would exist to supply the HLW and TRUW for a repository containing 70,000 MTU equivalent of wastes. Each reprocessing plant was assumed to have the capacity to process $1,500 \mathrm{MTU} / \mathrm{yr}$, for a total of 35,000 MTU during its lifetime.

\subsubsection{Capital Costs for TRUW Treatment Facilities}

The capital costs include the cost of constructing the facility and associated service areas, and the installed cost of the equipment to process the wastes. The cost estimates for this study are based on the cost analyses from a related study (Mckee et a1. 1984), where applicable. When estimates were not available, they were approximated by the authors based on the costs for treatment systems in the Mckee et al. (1984) study, taking into account the physical size and processing capacity of the equipment, the cell space required, and the complexity of the process. 
It is assumed that a high-level liquid waste (HLLW) vitrification facility and lag storage facilities for HLW and 6 months' production of TRUW (both before and after treatment) exist for each of the strategies studied. The cost estimates reflect the fact that the post-treatment TRUW lag storage facility needs are affected by the volume reduction achieved in treating the TRUW.

The capital costs for the HLLW waste vitrification, storage, waste assay, compaction, incineration, and melting operations are taken directly from the McKee study and adjusted slightly to reflect the processing quantities used in this report. For the other operations, a consensus was reached for capital costs based on the authors' knowledge of similar operations relative to the estimates in the McKee study. Table 8.1 lists amortized capital costs based on 1,500 MTU and 70,000 MTU reprocessed for two reprocessing plants. Details of the capital costs are given in Appendix D.

The reprocessing plants and their treatment facilities are assumed to be privately owned. The amortized capital costs including an allowance for profit, taxes, and startup costs are based on a commercial facility and are assumed to be $25 \%$ of the initial total capital cost per year for the life of the plant.

TABLE 8.1. Amortized Capital costs for the Six TRUW Treatment Options(a)

\begin{tabular}{|c|c|c|c|c|c|c|c|c|}
\hline \multirow[b]{2}{*}{ Waste Type } & \multirow{2}{*}{$\begin{array}{c}\text { MTU } \\
\text { Basis }\end{array}$} & \multicolumn{7}{|c|}{ Cost by Option, $\$ M$} \\
\hline & & 1 & 2 & 3 & -4 & $5 \bar{A}$ & $5 \mathrm{~B}$ & 6 \\
\hline TRUW & 1,500 & 16.5 & 24.4 & 26.8 & 37.1 & 42.4 & 49.9 & 37.5 \\
\hline HLW & 1,500 & 42.4 & 42.4 & 42.4 & 42.4 & 49.9 & 42.4 & 42.4 \\
\hline Total & & 58.9 & 66.8 & 69.2 & 79.5 & 92.3 & 92.3 & 79.9 \\
\hline TRUW & $70, \mathrm{D} 00$ & 770 & 1,140 & 1,250 & 1,730 & 1,980 & 2,330 & 1,750 \\
\hline HLW & 70,000 & 1,980 & $\underline{1,980}$ & 1,980 & $\underline{1,980}$ & 2,330 & 1,980 & 1,980 \\
\hline Total & & 2,750 & 3,120 & 3,230 & 3,710 & 4,310 & 4,310 & 3,730 \\
\hline
\end{tabular}

(a) Values are shown in more significant figures than the accuracy of the data to maintain consistency of the calculations. 


\subsubsection{Operating Costs for TRUW Treatment Facilities}

The operating costs were taken from the Mckee study when available. The operating costs not available in the McKee study were approximated by the authors. The operating cost was assumed to include labor, utilities, and consumable materials. The cost of purchasing containers to package the waste was estimated separately to give a total operating cost.

The operating costs available from the Mckee study were adjusted to reflect the quantities of processed waste in this study. The operating costs approximated by the authors were assumed to be a fraction of the capital costs. The fractions used were derived from an analysis of the costs in DOE/ET-0028 (U.S. DOE 1979). The fractions vary somewhat, depending on the type of operation. Details of the operating costs are given in Appendix $D$. The operating costs for each option are given in Table 8.?.

TABLE 8.2. Operating costs for the Six TRUW Treatment Options (a)

\begin{tabular}{|c|c|c|c|c|c|c|c|c|}
\hline \multirow[b]{2}{*}{ Waste Type } & \multirow{2}{*}{$\begin{array}{c}\text { MTU } \\
\text { Basis } \\
\end{array}$} & \multicolumn{7}{|c|}{ Cost by Option, $\$ M$} \\
\hline & & 1 & 2 & 3 & $\frac{1}{4}$ & $5 A$ & $5 \mathrm{~B}$ & 6 \\
\hline TRUW & 1,500 & 9.8 & 6.9 & 6.1 & 10.1 & 12.6 & 14.6 & 9.5 \\
\hline$H L W$ & 1,500 & 11.1 & 11.1 & 11.1 & 11.1 & 13.4 & 11.1 & 11.1 \\
\hline Total & & 20.9 & 18.0 & $17 . ?$ & 21.2 & 26.0 & 25.7 & 20.6 \\
\hline TRUW & 70,000 & 460 & 320 & 280 & 470 & 590 & 680 & 440 \\
\hline HLW & 70,000 & 520 & 520 & 520 & 520 & 620 & 520 & 520 \\
\hline Total & & 980 & 840 & 800 & $99 n$ & 1,210 & 1,200 & 960 \\
\hline
\end{tabular}

(a) Values are shown in more significant figures than the accuracy of the data to maintain consistency of the calculations.

\subsubsection{Sumnary of TRUW Treatment Facility Costs}

The life-cycle capital charges and operating costs (excluding decommissioning costs) for two $1,50011 T U / y r$ reprocessing facilities processing a total of 70,000 MTU are shown for each treatment option in Table 8.3. 
TABLE 8.3. Summary of TRUW Facility Amortized Capital and Operating
Costs for the Six TRUW Treatment Options

\begin{tabular}{|c|c|c|c|c|c|c|c|c|}
\hline \multirow[b]{2}{*}{ Waste Type } & \multirow{2}{*}{$\begin{array}{c}\text { MTU } \\
\text { Bas is } \\
\end{array}$} & \multicolumn{7}{|c|}{ Cost by Dption, $\$ M$} \\
\hline & & 1 & 2 & 3 & 4 & $5 A$ & $5 \mathrm{~B}$ & 6 \\
\hline TRUW & 1,500 & 26.3 & 31.3 & 32.9 & 47.2 & 55.0 & 64.5 & 47.0 \\
\hline HLW & 1,500 & 53.5 & 53.5 & 53.5 & 53.5 & 63.3 & 53.5 & 53.5 \\
\hline Total & & 79.8 & 84.8 & 86.4 & 100.7 & 118.3 & 118.0 & 100.5 \\
\hline TRUW & 70,000 & 1,230 & 1,460 & 1,540 & 2,200 & 2,570 & 3,010 & 2,190 \\
\hline HLW & 70,000 & 2,500 & 2,500 & 2,500 & 2,500 & 2,950 & 2,500 & 2,500 \\
\hline Tota1 & & 3,730 & 3,960 & 4,040 & 4,700 & 5,520 & 5,510 & 4,690 \\
\hline
\end{tabular}

(a) Values are shown in more significant figures than the accuracy of the data to maintain consistency of the calculations.

\subsection{TRANSPORTATION COSTS}

The processed TRUW and HLW are assumed to be shipped by railcar to a commercial repository 2,000 miles from the waste processing facility. Similarly, the LLW resulting from decontamination or dilution is to be transported by truck to a commercial LLW disposal site in the eastern U.S., 300 miles from the waste processing facility. Transportation is to be provided by private industry.

The transportation cost for TRUW and HLW consists of a cask-leasing fee and general freight charges (including security if required). Except for the shipment of the waste in 160-gal containers (see footnote (c) on Table 0.5), the cask leasing fee is taken directly from the Mckee study. The freight charges were derived from information provided by McNair et al. (1984). The cost of transporting the $L L W$ is based on information in DOE/LLW-6Td (EG\&G Idaho, Inc. 1983).

The transportation costs for TRUW, LLW, and HLW are given in Table 8.4, based on 1,500 MTU/yr reprocessed and on 70,000 MTU total fuel reprocessed from two reprocessing plants. See Appendix 0 for details of the transportation costs. 
TABLE 8.4. Transportation Costs for the Six TRljw Treatment Options(a)

\begin{tabular}{|c|c|c|c|c|c|c|c|c|}
\hline \multirow[b]{2}{*}{ Waste Type } & \multirow{2}{*}{$\begin{array}{r}\text { MTU } \\
\text { Basis } \\
\end{array}$} & \multicolumn{7}{|c|}{ Cost by Option, $\$ M$} \\
\hline & & 1 & 2 & $\overline{3}$ & 4 & $5 A$ & $5 B$ & 6 \\
\hline TRIJW & 1,500 & 30.1 & 6.8 & 2.6 .3 & 2.6 & 0.2 & 0.4 & 2.45 \\
\hline LLW & $1,5 \cap 0$ & 0 & 0 & 0 & 0 & 0.9 & 0.9 & 0.04 \\
\hline HLW & 1,500 & 6.7 & 6.7 & 6.7 & 6.7 & 11.5 & 6.7 & 6.7 \\
\hline Tota 1 & & 36.8 & 13.5 & 33.0 & 9.3 & 12.6 & 8.0 & 9.2 \\
\hline TRIJW & 70,000 & 1,400 & 320 & $1,2.30$ & 120 & 10 & $2 n$ & 110 \\
\hline$L L W$ & 70,000 & 0 & 0 & $n$ & 0 & 40 & 40 & 2 \\
\hline$H L W$ & 70,000 & 310 & 310 & 310 & 310 & 540 & 310 & 310 \\
\hline Total & & 1,710 & 630 & 1,540 & 430 & 590 & 370 & 420 \\
\hline
\end{tabular}

(a) Values are sometimes shown in more significant figures than the accuracy of the data to maintain consistency of the calculations.

\subsection{DISPOSAL COSTS}

The disposal costs for TRIJW and HLW were estimated using the RECON repository cost model (Clark et al. 1983), which calculates the life-cycle construction, operating, and decommissioning costs of geologic repositories. The repository used is hased on the 1983 reference design concept for BWIP (Kaiser Engineers Inc./Parsons, Brinkerhoff, Duade, and Douglas, Inc. 1983). The repository is assumed to have the capacity to accept the 70,000 MTU of reprocessed waste used as the basis in this study. It was also assumed that the RH TRUW and HLW would he remotely placed into horizontal horeholes in the walls of the underground tunnels, and that the CH TRLW would be co-emplaced with the HLW with long-lived overpacks. The computer model includes all costs for repository design, surface and subsurface construction and excavation, backfilling, sealing, and decommissioning; and operating costs for waste receipt, package transport, and emplacement. Because the repository disposal costs are related to the relative amounts of the different types of wastes received, the repository costs were calculated based on the amounts of each waste type and the canister sizes for each treatment option in this study (see Table 7.9). 
The life-cycle disposal costs generated by RECON are given in Table 8.5, as well as the LLW disposal costs for LLW generated in Options 5 and 6 . It should be noted that as the TRUW volumes decrease, the TRUW disposal costs also decrease. However, the HLW costs increase, since facility costs are shifted to HLW. Thus it is important to consider total HLW and TRUW costs when estimating TRUW disposal costs.

The LLW costs are based on the Rarnwell LLW disposal facility rate schedule (see Appendix E). Additional details of the disposal cost calculations are given in Appendix $D$.

TABLE 8.5. Disposal Costs for the Six TRUW Treatment Options (a)

\begin{tabular}{|c|c|c|c|c|c|c|c|c|}
\hline \multirow[b]{2}{*}{ Waste Type } & \multirow{2}{*}{$\begin{array}{c}\text { MTU } \\
\text { Bas is } \\
\end{array}$} & \multicolumn{7}{|c|}{ Cost by Cotion, $\$ M$} \\
\hline & & 1 & 2 & 3 & 4 & $5 A$ & $5 \mathrm{~B}$ & 6 \\
\hline TRUW & 1,500 & 47.6 & 31.1 & 39.6 & 12.6 & 4.1 & 4.1 & 13.5 \\
\hline LLW & 1,500 & 0 & 0 & 0 & $n$ & 11.6 & 11.6 & 0.07 \\
\hline HLW & 1,500 & 56.6 & 59.8 & 59.6 & 64.5 & 68.8 & 67.7 & 63.7 \\
\hline Total & & 104 & 91 & 99 & 77 & 85 & 83 & 77 \\
\hline TRUWW & 70,000 & 2,230 & $1,45 n$ & 1,850 & 590 & 190 & 190 & 630 \\
\hline LLW & $70, n 00$ & 0 & 0 & 0 & 0 & 540 & 540 & 3 \\
\hline HLW & 70,000 & 2,640 & 2,790 & 2,770 & 3,010 & 3,210 & 3,160 & 2,970 \\
\hline Total & & 4,870 & 4,240 & 4,620 & 3,600 & 3,940 & 3,890 & 3,600 \\
\hline
\end{tabular}

(a) Values are shown in more significant figures than the accuracy of the data to maintain consistency of the calculations.

\subsection{TOTAL LIFE-CYCLE. COSTS}

The total life-cycle costs (exclusive of decomissioning and any R\&D costs) for management of TRUW, HLW, and LLW from the six TRUW treatment options are given in Table 8.5. These values are taken from Tables $8.3,8.4$ and 8.5 . 
TABLE 8.6. Total Life-Cycle Cost for Management of TRUW, HLW, and LLW(a)

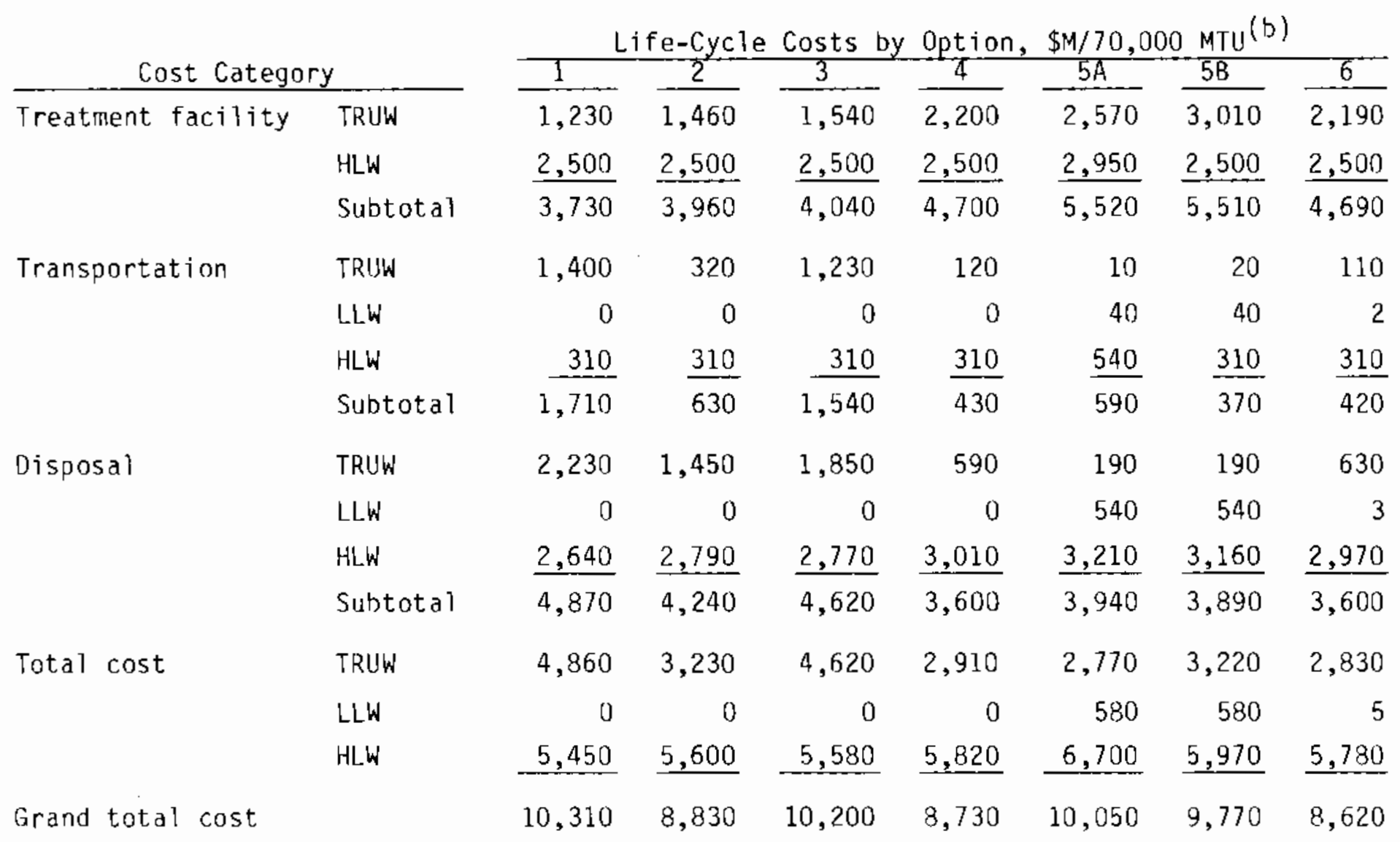

(a) Values are shown in more significant figures than the accuracy of the data to maintain consistency of the calculations.

(b) Life-cycle cost $=($ cost based on $1,500 \mathrm{MTU}) \times(70,000 \mathrm{MTU} / 1,500 \mathrm{MTU})$. 


\subsection{REFERENCES}

Clark, L. L., et al. 1983. RECON: A Computer Program for Analyzing Repository Economics. PNL-4466, Pacific Northwest Laboratory, Richland, Washington.

EG\&G Idaho, Inc. 1983. Directions in Low-Level Radioactive Waste Management, An Analysis of Low-Level Waste Disposal Facility and Transportation Cost. DOE/LLW-6Td, Idaho Falls, Idaho.

Kaiser Engineers Inc./Parsons, Brinkerhoff, Quade, and Douglas, Inc. 1983. Conceptual System Design Description, Nuclear Waste Repositories in Basalt, Project B-301. BWI-SD-006, Rockwel] Hanford Operations, Richland, Washington.

McKee, R. W., L. L. Clark, P. M. Daling, J. F. Nesbitt and J. L. Swanson. 1984. "Economic Analysis of Waste Management System Alternatives for Reprocessing Wastes." Waste Management 1984, University of Arizona, Tucson.

McNair, G. W. et al. 1984. Truck and Rail Charges for Shipping Spent Fuel and Nuclear Waste. PNL-4064, Pacific Northwest Laboratory, Richland, washington.

U.S. Department of Energy. 1979. Technology for Commercial Radioactive Waste Management. DOE/ET-0028 in 5 volumes, U.S. DOE, Washington, D.C. 


\section{9.ก COMPARISON OF TREATMENT STRATEGIES}

The primary emphasis of this study is the selection and evaluation of potential treatment methods for TRUW. Waste management system cost analyses of the selected options were provided in Section 8 . The factors of waste acceptance at the repository and the process and operational characteristics are discussed and compared in this section. Following the discussions of these two factors, a summary and comparison of the various treatment options are presented.

\subsection{WASTE FORH CHARACTERISTICS}

The general requirements for the waste forms were reviewed in Section 4 in conjunction with the regulatory requirements for waste disposal. It was recognized that the final disposal method for TRIJW has not been established, although geologic disposal is assumed in this study. Also, the absolute acceptability of a waste for disposal cannot be stated with certainty, since detailed waste form requirements have yet to be established. Obviously, the better the properties of the waste form, the greater the likelihood of its being considerer acceptable for disposal.

From the analysis in Section 4, it can be noted that the waste form may he required to have specific characteristics, particularly for deep geologic disposal. The characteristics from Table 4.1, which can he controlled by waste form selection, are compared in Table 9.1. Several factors presented in Table 4.1 are similar and are thus considered together in Table 9.1. For example, solubility, leach rate, and release rate (from the near field at the repository) are all measures of chemical durability that are included in Table 9.1 under "Release Rate." The following are considerations for the qualitative evaluations in Table 9.1 .

- Combustible materials are present in as-generated wastes and are less combustible (and will not propagate a flame front) when mixed with cement. Incineration removes all combustible and biodegradable material from the waste. 
TABLE 9.1. Comparison of Likely Waste Form Characteristics for the Six TRUW Treatment Options, with Potential Requirements

\begin{tabular}{|c|c|c|c|c|c|}
\hline & Treatment notion & $\begin{array}{l}\text { Combustible } \\
\text { Material Present }\end{array}$ & $\begin{array}{c}\text { Particulatas } \\
\text { Presen- }\end{array}$ & $\begin{array}{l}\text { Pvronhoric } \\
\text { Free Liauid } \\
\text { Present }\end{array}$ & $\begin{array}{l}\text { Fas } \\
\text { Material } \\
\text { Present }\end{array}$ \\
\hline & No treatmant & Yes & Yes & Nn & $\begin{array}{l}\text { Possible } \\
\text { (hulls) }\end{array}$ \\
\hline 2. & Minimum treatment & Yes & Yes & No & $\begin{array}{l}\text { Likely } \\
\text { (hull } \\
\text { fines) }\end{array}$ \\
\hline 3. & Minimum number orocesses & $\begin{array}{l}\text { Yes, but } \\
\text { cemented }\end{array}$ & No & Not likeiv & niluted \\
\hline 4. & $\begin{array}{l}\text { Maximum volume reduction } \\
\text { without decontamination }\end{array}$ & Sliaht & No & No & No \\
\hline 5. & $\begin{array}{l}\text { Maximum volume reduction } \\
\text { wth decontamination }\end{array}$ & S1 ight & Stiaht & No & Treated \\
\hline 6. & Noncombustible waste forms & None & No & $\mathrm{NO}$ & No \\
\hline
\end{tabular}

\begin{tabular}{|c|c|c|c|c|c|}
\hline $\begin{array}{l}\text { Genaration } \\
\text { Likelv }\end{array}$ & $\begin{array}{c}\text { Subject to } \\
\text { Riodenradation }\end{array}$ & $\begin{array}{l}\text { Structural } \\
\text { Stabilitv } \\
\end{array}$ & $\begin{array}{l}\text { Void } \\
\text { Soaces } \\
\text { Present } \\
\end{array}$ & Release Rate & $\begin{array}{l}\text { Radiation } \\
\text { Resistance }\end{array}$ \\
\hline Possible & Possible & Nome & Yes & $\begin{array}{l}\text { Some forms } \\
\text { have hiah } \\
\text { potential } \\
\text { release }\end{array}$ & $\begin{array}{l}\text { Probably } \\
\text { Door }\end{array}$ \\
\hline Possible & Possible & Poor & YAS & $\begin{array}{l}\text { Some forms } \\
\text { have hiah } \\
\text { Dotentlal } \\
\text { release }\end{array}$ & $\begin{array}{l}\text { Probablv } \\
\text { Door }\end{array}$ \\
\hline Possible & $\begin{array}{l}\text { Reduced } \\
\text { potential }\end{array}$ & Good & No & $\begin{array}{l}\text { Hiah } \mathrm{nH} \\
\text { will reduce } \\
\text { actinide } \\
\text { release rates }\end{array}$ & $\begin{array}{l}\text { Prohahiv } \\
\text { fair }\end{array}$ \\
\hline No & No & Goor & No & Low & $\begin{array}{l}\text { Generally } \\
\text { gond }\end{array}$ \\
\hline No & No & Most forms & Some & Low & Good \\
\hline No & No & food & No & Low & Good \\
\hline
\end{tabular}


- Particulates will be present in several wastes, such as fluorinator fines and cladding hulls, unless immobilized. Particulates have high surface areas that tend to increase the release potential.

- No liquids are anticipated as a direct waste stream. A poorly prepared cement mixture, however, may have excess water after curing (the free liquid could be used for subsequent cementing hatches). nuality control checks should detect and prevent free liquid from being shipped.

- Cladding hull fines can be pyrophoric under certain conditions, and crushing of the hulls may generate additional fines. Diluting the hulls with cement should reduce the pyrophoric tendency, and forming metal billets should eliminate any pyrophoric potential.

- Gas generation may he detrimental in contributing to release during storage and disposal. Radiolys is of organics and water in cement is a potential source of gas generation.

- Low bulk density materials do not have structural stability without a supporting canister. Structural stability for about the first 100 years (during the emplacement and potential retrievability period at the repository) may be important to prevent breaching of the overburden ahove a repository. However, over the long term at the depth of a deep geologic repository, the potential for breaching the overburden resulting from collapse of the waste is negligible, and subsidence of the overburden is probably not a major concern.

- Structural stability is generally improved with lower void space. However, as stated above, the importance of structural stability over the long term may or may not be important.

- The release rates from most of these waste forms have not been measured, even in comparison with HLW forms. Therefore, it is difficult to judge whether the materials could meet the stringent 10 CFR 60 (U.S. NRC 1983) release rate requirement of less than 1 part in 100,000 per year, although some comparison of TRUW forms has been made (Ross et al. 1991). 
- Radiation resistance is a consideration for maintenance of structural stability and for possible gas generation from radiolysis. Some of the forms have not been well characterized for these properties, and future development will need to emphasize waste form testing along with process development (Roberts 1981). The expected waste form performance given in Tahle 9.1 takes these considerations into account.

As might be anticipated, waste forms from 0ption 1 (no treatment) and Option 2 (minimum treatment) have the greatest potential for heing unacceptable for deep geologic repository disposal. The major concerns are with 1) hull fines, which may he reactive and pyrophoric; 2) combustible materials, which are subject to biodegradation, gas generation, and fire; 3) particulate material, which has the potential for higher releases of radioactivity, particularly during accidents with canister failure; and 4) high potential radionuclide release rates. High-integrity canisters may provide an intermediate-term solution for all of these concerns.

Option 3 (minimum number of processes and products) involves cementing all of the wastes and thus reduces the potential waste form concerns identified above, hut it does not completely eliminate them. Additional testing and characterization would appear to be necessary should this option be selected.

Option 4 (maximum volume reduction without decontamination) produces generally good waste form properties. The remaining concerns result from the residual quantities of organic materials from the treatment of SAC wastes. Possible alternative treatments of SAC wastes are noted in other options.

Option 5 (maximum volume reduction with decontamination) presents concerns from the recognition that decontamination of all the material may not be possible, which could leave some material unchanged from its as-generated condition.

Option 6 (noncombustible waste forms) results in waste forms with the most favorahle characteristics. This is primarily hecause of the limitations noted for treating GPT and SAC wastes noted for Options 4 and 5. 


\subsection{PROCESSING CHARACTERISTICS}

The processing characteristics for each treatment option have been evaluated qualitatively. Characteristics have been evaluated in the four subcategories of 1) process and operational safety, 2) complexity of the treatment system, 3) status of technology, and 4) flexibility of the processes. These evaluations are given in the following subsections.

\subsubsection{Process and Operational Safety}

The safety of the treatment methods concerns the risk to operational staff and the puhlic from the process operations, and includes consideration of inherent accident potential with respect to chemicals, fire or explosions, mechanical operations, electrical accidents, and radiochemical releases. A11 of the processes would be safe when implemented, but some inherent safety concerns require that additional safety provisions be incorporated into the design and operational procedures. Detailed risk analyses, which are heyond the scope of this study, would he required to quantify the relative safety of the different processes.

Chemical hazards are determined hased on the use of hazardous materials and the recognition that handling such materials (e.g., acids, hases, or toxic materials) can present accident potential to personnel. However, the processes selected for this study generally do not require the use of these agents; thus all options have low chemical hazards. In Option 5, cryogenic cracking of the cladding hulls would require the use of liquid nitrogen, which requires some care to avoid freezing or gas pressurization.

Fire or explosion hazards are related to the generation of hull fines, the handling of organic and combustible materials, and the use of high temperature operations.

Mechanical hazards are a concern where operating personnel are in the proximity of mechanical equipment and where high pressures are used.

Electrical hazards are approximately a function of the amount of electrically powered equipment used. Flectrical power is likely to he handied safely, and thus none of the options would likely pose a major hazard to operating personne1. 
Radiochemical release is related to the need to handle radioactive materials and to treat of gases from the processes, particularly the processes at high temperatures, which have a higher potential for volatilization of radionuclides. For example, metal melting may pose a volatilization concern because tritium in the cladding hulls will be partially or totally volatilized during melting and will need to he captured in the off-gas system.

The qualitative evaluation of the process and operational safety is summarized in Column 2 of Table 9.?. A review of Table 9.2 shows that the simpler the treatment system, the lower the potential hazard. Options 1, 2, and 3 appear to have the most inherent process and operational safety. (However, it should be noted again that the evaluations in Tahle 9.2 are relative, and all of the processes would pose a low risk as implemented.) Additional details on development of the evaluation are given in Appendix $F$.

\subsubsection{Complexity of the Treatment System}

The complexity of the treatment system can be qualitatively estimated by the number of treatment processes and the number of steps in each process. (In addition, the more complex the treatment, the greater the cost of process equipment, facility space and operations, as identified in Section 8 ).

The results of the qualitative evaluation of treatment system complexity are summarized in Column 3 of Table 9.2. The table shows that the more complete treatment options (i.e., Options 4, 5, and 6) involve more complex treatment systems. Additional details of the evaluation of system complexity are given in Appendix $F$.

\subsubsection{Status of Technology}

The status of technology is important in selecting treatment strategies. The time required for implementation of the technology, the cost of R\&D, and the availability and experience in design and operation of treatment systems are all related to the status of technology. These factors were estimated qualititatively in this study, and the overall status of technology was identified by classification of the development stage of the major process steps. It should be recognized that most of these technologies have been developed for other types of radioactive waste, particularly defense TRUW and LLW. 
TABLE 9.2. Overall Oualitative Comparison of Processing Characteristics for the Six TRUW Treatment Options (a)

\begin{tabular}{|c|c|c|c|c|c|}
\hline Treatment Option & $\begin{array}{l}\text { Process and } \\
\text { Operational } \\
\text { Safety }\end{array}$ & $\begin{array}{l}\text { Process } \\
\text { Simplicity } \\
\end{array}$ & $\begin{array}{l}\text { Status of } \\
\text { Technology } \\
\end{array}$ & $\begin{array}{l}\text { Process } \\
\text { Flexibility } \\
\end{array}$ & Overall (b) \\
\hline 1. No treatment & Very good & Very good & Very aood & Very good & Very good \\
\hline 2. Minimum treatment & Good & Good & Very good & Good & Good + \\
\hline $\begin{array}{l}\text { 3. Minimum number } \\
\text { of processes } \\
\text { and products }\end{array}$ & Good & Good & Very good & Good & Good + \\
\hline $\begin{array}{l}\text { 4. Maximum volume } \\
\text { reduction without } \\
\text { decontamination }\end{array}$ & Fair & Modarate & Moderate & Fair & Fair + \\
\hline $\begin{array}{l}\text { 5. Maximum volume } \\
\text { reduction with } \\
\text { decontamination }\end{array}$ & Moderate & Fair & Fair & Fair & Fair \\
\hline $\begin{array}{l}\text { 6. Noncombustible } \\
\text { waste forms }\end{array}$ & Moderate & Moderate & Good & Good & Good \\
\hline
\end{tabular}

(a) The relative ratings are from very good (the most favorable) to fair (the least favorable in the aroupl. No attampt was made to weight the four categories.

(b) A "+" indicates that the relative rating falls between that indicated and the next highest rating.

Oevelopment of technology can be expected to continue for both defense TRIJW and commercial LLW, reducing the amount of technology development necessary for commercial TRIJW. Timing does not currently appear to he a major concern because of the delay in the implementation of reprocessing in the commercia? nuciear fuel cycle. The cost for R\&n, while significant, can be expected to be small (in the range of a few tens of millions of dollars) compared to the potential savings from implementation of the technology (up to 1.7 billion dollars). R\&D costs for commercial wastes may be reduced hy delaying development of the technology, since similar technology is being developed for defense wastes, but costs could be increased if the delay results in a shortener development schedule that requires parallel development efforts. Total development (defense plus commercial) costs may not he much different regardless of the schedule.

The overall status of technology was identified by classification of the stage of development of the major process steps. Timing does not appear to be a major concern hecause a major TRIJ treatment system will not be needer until 
some time in the future. The cost of R\&D for treatment systems can be significant and should not exceed the value of savings resulting from the treatment optimization. Availability of maintenance service and experience can provide economic benefits.

The results of the qualitative evaluation of the technology status of the treatment options are summarized in Column 4 of Table 9.?. As might be expected, the status of technology for the simpler treatment options (Options 1, 2, and 3) is the most favorahle. Additional details of the evaluation of the status of technology are given in Appendix F.

\subsubsection{Flexibility of Processes}

In some of the treatment options, the individual treatment processes are expected to treat wastes with a wide variety of characteristics. Some questions remain regarding the ability of all of the processes to perform as desired. The qualitative evaluation of the flexibility of the treatment processes to accommodate the anticipated variations in waste streams is summarized in Column 5 of Table 9.2 .

The processes all appear to be appropriate, with some having minor potential difficulties. This is largely because the process selection during the early part of the study eliminated processes with serious questions. Additional details of the evaluation of process flexibility are given in Appendix $F$.

\subsubsection{Overall Evaluation of Processing Characteristics}

The overall qualitative evaluation of the processing characteristics is given in the last column of Table 9.2. This evaluation is a composite of the four factors given in the prior four columns. No attempt was made to weight the four factors; thus they were all assumed to be of approximately equal weight.

Table 9.2. shows that the simpler treatment options (Options 1, ?, and 3) possess the more favorable processing characteristics. However, Option 6 follows closely behind the first three, while Options 4 and 5 are significantly less favorable. 


\subsection{OVFRALL COMPARISON OF TREATMENT OPTIONS}

In this subsection the six options are compared on an overall basis using the quantitative economic considerations of the waste management system from Section 8 (Table 8.6 ) and the qualitative waste form and processing characteristics given in Subsections 9.1 (Table 9.1) and 9.2. (Table 9.2). From this information, the options are ranked 1 (most favorable) through 6 (least favorable) in each of the three major comparison categories. This ranking is shown in Columns ?, 3, and 4 of Table 9.3. This technique was used to force discrimination among the various categories, even though the differences were small in some cases.

An approximate overall ranking of the options is given in Column 5 of Table 9.3. This ranking, obtained by simple addition of the numbers in the prior three columns, inherently assumes equal weighting of the categories in the first three columns. However, this simple ranking system provide some valuable insights, indicating that Option 6 appears to he the most favorable and 0ptions 1 and 5 appear to be the least favorable. The more extensive treatment options (0ptions 4, 5, and 6) are ranked the highest in the waste form category, with the ranking for option 6 as the most favorable. Option 6 also presents the most favorable system economics and has the most favorable

TARLE 9.3. Summary Ranking of the Six TRUW Treatment Options (a)

\begin{tabular}{|c|c|c|c|c|}
\hline Option & $\begin{array}{l}\text { System } \\
\text { Economics }\end{array}$ & $\begin{array}{c}\text { Waste Form } \\
\text { Characteristics }\end{array}$ & $\begin{array}{c}\text { Processing } \\
\text { Characteristics } \\
\end{array}$ & $\begin{array}{c}\text { Approximate } \\
\text { Overal1 } \\
\text { Ranking (b) }\end{array}$ \\
\hline 1 & 6 & 6 & 1 & 13 \\
\hline$?$ & 3 & 5 & $?$ & 10 \\
\hline 3 & 5 & 4 & 3 & 12 \\
\hline 4 & 2 & $?$ & 5 & 9 \\
\hline 5 & 4 & 3 & 6 & 13 \\
\hline 6 & 1 & 1 & 4 & 6 \\
\hline
\end{tabular}

(a) Ranking is from 1 (most favorable) to 6 (least favorable of the group).

(b) Approximate overall ranking is by addition of the prior three values for each optinn, with the lower values being the most favorable. 
processing characteristics of the more extensive treatment options (Options 4 , 5 , and 6). Option 5 appears to be the least favorable of the more extensive treatment options.

Although waste form requirements may not be known currently, they may well provide "go/no-go" bases for evaluating the waste forms for the various strategies. If so, the options with the lower waste form ranking could well be eliminated, and the better waste forms would have a greater chance of meeting the requi rements.

Based on these evaluations, it appears that Option 6 may have the most favorable characteristics of all the options studied. Option 4 appears to have the next most favorable characteristics of the more extensive treatment options, and ranks least favorable only in the processing characteristics (which could likely be improved with development).

The strength of selecting Option 6 can be illustrated by noting that even with a douhling of the relative cost of processing (the characteristic with the lowest ranking for Option 6), it would still be favored over the other options. Since it has the highest ratings for both economics and waste form characteristics, Option 6 would be preferred as long as the combined weighting for economics and waste form is as low as $40 \%$ of the total, hased on this analys is method.

Options 1,2 , and 3 would require little or no $R \& D$, and their relative ranking would likely he unaffected by further technology development. Technology for treating contact-handled TRUW for Option 6 is being developed for several different types of defense waste. Development of shredding, incineration, and cementing technology for commercial wastes can be limited to remotizing the processes and equipment modifications for the specific waste types. No totally new technology is needed. (a)

(a) The major processes for Option 6 have some history in radioactive waste treatment. Melting of metals was originally considered for treating cladding hulls in the early 1970s, and melting technology is well established cornmercially for a wide variety of metals. Evaluation of alternative melting processes has recently been completed (Montgomery and Nesbitt 1983), and initial tests have been completed that show much promise for vacuum induction melting (Montgomery et al. 1984). Shredding, incineration, and cementing technology was selected by INFL (Clements et al. 1984) and other sites with defense TRIJW for treatment of TRUH. 


\subsection{REFERENCES}

Clements, T.L., et al. 1984. Processing and Certification of Defense Transuranic Wastes at the INEL. EGT्रa-M-26083, EGRG Co., Idaho Falls, Idaho.

EGG, Co. 1982. Conceptual Design Report for TAN 607 Process Experimental Pijot Plant (PREPP). EGQG Co., Idaho FalTs, Itaho.

Montgomery, D. R. 1984. Consolidation of Simulated Nuclear Metallic Waste by Vacuum Coreless Induction Meiting. PNL-5254, Pacific Northwest Laboratory, Richland, Washington.

Montgomery, D. R. and J. F. Nesbitt. 1983. Review and Evaluation of Metallic TRU Nuclear Waste Consolidation Methods. PNL-4754, Pacific Northwest Laboratory, Richland, Washington.

Roberts, F.P. 1981. An Assessment of Radiation Effects in Defense Transuranic Waste Forms. $P \overline{N L}-3913$, Pacific Northwest Laboratory, Richland, Washington.

Ross, W. A., et al. 1981. "A Comparative Assessment of TRU Waste Forms and Immobilization Processes." In Scientific Bas is for Nuclear Waste Management. Elsevier Science Publishing Co. New Pork.

U.S. Nuclear Regulatory Commission. 1984. Code of Federal Regulations, Title 10, Energy; Part 60, Disposal of High-Level Radioactive Wastes in Geologic Repositories Technical Criteria. Final Rule, U..S. Federal Register, Vol. 48, No. 120, June 21, 1983, pp. 28194-28229. (J.S. NRC, Washington, D.C. 


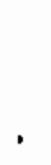




\subsection{CONCLIJSIONS AND RECOMMENDATIONS}

This study evaluates six options for the treatment of TRIJ from a reference reprocessing plant. These options represent specific treatment strategies involving no treatment, minimum processing, minimum number of processes and products, maximum volume reduction, decontamination to remove material from the TRIJW category, and the preparation of waste forms without combustibles. Treatment processes were selected to correspond to each of these ohjectives, and the anticipated volumes of treated waste from a Barnwell-type plant were calculated. These volumes were used with the RECON computer code (Clark et al. 1983) and Chem-Nuclear LLW disposal costs (see Appendix E) to calculate disposal costs for the various options. Transportation and treatment costs were also estimated and sumed with disposal costs to compare the costs of the six options. Decommissioning and R\&D costs have not heen included in the economic analysis, but they will he much lower than the overall system costs that have heen included. The options were also compared hased on waste form and process considerations. Rased on this study, the following conclusions and recommendations are warranted:

- Option 6, noncombustible waste forms, is the preferred option from both economic and waste form standpoints, and 0ption 4, maximum volume reduction without decontamination, is the next preferred alternative. The economic incentive to treat the waste is a savings of about $\$ 1.6$ billion, based on the waste from reprocessing 70,000 MITI of spent fuel and on comparison with the no treatment option. Options 4 and 6 treat the metallic waste hy melting and the combustible wastes hy incineration. The processes in option 6 result in only two waste forms: metal ingots and cement that incorporate the wastes. Development of the technology for this option, including metal melting, incineration, shredding, and cementing, should he given first priority.

- When compared with the no treatment option, alt of the treatment. options in this study offer economic and waste form incentives, and 
thus indicate the importance of treating TRUW. This conclusion was also reached by Mckee et al. (1984) in their study of commercial TRIJW.

- Fuel cladding hulls and hardware comprise the most important TRUW streams from reprocessing because of their large volume, high radioactivity, and the costs for their management. The processes with the greatest economic benefits are those with technology that produces large volume reductions of the fuel cladding hulls and hardware. Decontamination applied to hulls alone may be an effective treatment for this waste stream, hut this will require verification. Some of the radioactivity (i.e., activation products) in cladding hulls are not removable by decontamination. Decontamination of other streams does not appear to be justified hecause of the added treatment costs and process complexity. A major consideration in decontamination of TRUW stems from the recognition that all of the wastes cannot be decontaminated, and thus other treatment methods must also be implemented, which increases processing complexity and treatment costs.

- There appear to be several incentives for incinerating combustible wastes, including volume reduction and the elimination of combustible materials from wastes sent to disposal. A direct comparison of incineration with alternative treatments was not possible from the final results and should be studied further.

- In evaluating the decontamination of fuel hardware, it was recognized that the high level of radiation from ${ }^{50}$ Co in these materials may require their disposal in a repository, both from an economic viewpoint and because of the difficulty that LLW sites have in handling the activity associated with this material.

- Volume reduction is a very important consideration from the perspective of overall system economics.

- Simple compaction of the wastes is economically attractive, but waste form characteristics remain a concern for disposal. 
- Combining small volumes of TRIW with HLW may be economic if it does not significantly increase $H \mathrm{LW}$ volume. However, treating the sludge resulting from hull decontamination hy this method is very costly hecause it increases the size of the HLW vitrification system required.

- HEPA filters are a major waste stream that can he significantly reduced in volume. HEPA filters, in addition to other materials, contain organic glues and aluminum spacers that complicate their treatment. The available data regarding treatment of filters are incomplete and should he developed further. Treatment of filters should be given high priority in R\&D planning with respect to specific waste types.

- One of the other problem waste materials is PVC; its high chloride content makes it unfavorahle for incineration and limits the combining of the residues from incineration with HLW glass. Thus there is an incentive to replace PVC with alternative materials that may simplify waste treatment and reduce its costs.

- Reduced waste generation, one method of volume reduction not considered in this report, should be evaluated, particularly in its potential impact on the design and operation of treatment facilities. With new practices it may he possible to reduce the volume of the wastes that need treatment for a much lower cost than the cost of treating the resulting wastes from current practices.

- Bevelopment and characterization of TRIJW forms are needer to allow assessment of their potential hehavior in disposal environments and their conformance with NRC and EPA requirements.

- This strategy analysis should he reviewed periodically as new technology is developed, as new practices are applied in fuel reprocessing, and as new applications for waste treatment are identified. 


\subsection{REFERENCE}

Clark, L. L., et al. 1983. RECON: A Computer Program for Analyzing Repository Economics. PNL-4466, Pactfic Northwest Lahoratory, Richland, Washington.

McKee, R. W., L. L. Clark, P. M. Daling, J. F. Nesbitt, and J. L. Swanson. 1984. "Economic Analys is of Waste Management System Alternatives for Reprocessing Wastes." Waste Management 1984, pp. 383-393. University of Arizona, Tucson. 
APPENDIX A

TRUW CHARACTERISTICS BY WASTE TYPE 
TABLE A.1. TRUW Characteristics by waste Type (Darr 1983)

\begin{tabular}{|c|c|c|c|c|c|c|c|}
\hline & & Containers/ & Container & $\begin{array}{l}\text { Quantity } \\
\text { Waste } \\
\end{array}$ & $\begin{array}{l}\text { Contained } \\
00 \mathrm{MTU}\end{array}$ & $\begin{array}{c}\text { TRU } \\
\text { Content, }\end{array}$ & $\begin{array}{l}\text { Container } \\
\text { Dose Rate, }\end{array}$ \\
\hline Waste Type & Stream & $1,500 \mathrm{MTU}$ & Size, gal & $\mathrm{ft}^{3}$ & $\mathrm{~kg}$ & & \\
\hline $\begin{array}{l}\text { Hulls and } \\
\text { hardware }\end{array}$ & 21 & 300 & 600 & $2.25 \mathrm{E} 4$ & $4.86 E 5$ & $2.2 E 4$ & $4.6 \mathrm{E} 6$ \\
\hline Filters (metal & $25 B$ & 51 & 80 & $1.80 \mathrm{E} 2$ & $6.63 \mathrm{E} 2$ & $3.70 \mathrm{E} 2$ & $1.30 \mathrm{E} 2$ \\
\hline & & 18 & 80 & $6.15 \mathrm{E} 1$ & $2.34 \mathrm{E} 2$ & $1.20 E 3$ & $4.0 \mathrm{E} 2$ \\
\hline & & 4 & 80 & $9.5 \mathrm{EO}$ & $5.2 \mathrm{E} 1$ & $3.0 \mathrm{E} 2$ & $2.30 \mathrm{E} 3$ \\
\hline & $25 \mathrm{C}$ & 3 & 600 & $3.8 \mathrm{E} 1$ & $1.35 \mathrm{E} 2$ & $2.0 \mathrm{E} 5$ & $8.0 \mathrm{E} 4$ \\
\hline & & 21 & 600 & $2.62 \mathrm{E} 2$ & $9.45 E 2$ & 2.0E6 & $8.0 \mathrm{E} 5$ \\
\hline & 45 & 33 & 80 & $6.6 \mathrm{E} 1$ & $4.29 E 2$ & $3.70 \mathrm{E} 2$ & $1.30 \mathrm{E} 2$ \\
\hline & & 11 & 80 & $2.2 \mathrm{El}$ & $1.43 \mathrm{E} 2$ & $1.20 \mathrm{E} 3$ & $4.10 \mathrm{E} 2$ \\
\hline & $52 \mathrm{~A}$ & 52 & 80 & $1.89 \mathrm{E} 2$ & $6.76 \mathrm{E} 2$ & $5.00 \mathrm{E} 3$ & $3.0 E-1$ \\
\hline & & 497 & 80 & $1.81 \mathrm{E} 3$ & $6.46 \mathrm{E} 3$ & 8.0E4 & $4.5 \mathrm{E} 0$ \\
\hline & & 251 & 80 & $9.14 \mathrm{E} 2$ & $3.26 \mathrm{E} 3$ & $6.0 E 5$ & $3.1 \mathrm{E} 1$ \\
\hline & $52 \mathrm{~B}$ & 1 & 55 & $3.0 \mathrm{E} 0$ & $3.8 \mathrm{E} 1$ & $4.00 E 3$ & $3.0 E-1$ \\
\hline & & 19 & 55 & $5.7 \mathrm{El}$ & $7.22 \mathrm{E} 2$ & $6.0 \mathrm{E} 4$ & $3.5 \mathrm{E} 0$ \\
\hline & & 30 & 55 & $9.0 \mathrm{E} 1$ & $1.14 \mathrm{E} 3$ & $3.0 \mathrm{E} 5$ & $1.7 \mathrm{EO}$ \\
\hline & $63 \mathrm{~A}$ & 2 & 600 & $3.0 \mathrm{E} 1$ & $9.0 \mathrm{E} 1$ & $8.0 E 4$ & $8.0 \mathrm{E} 4$ \\
\hline & & 18 & 600 & $2.70 \mathrm{E} 2$ & $8.10 \mathrm{E} 2$ & $8.0 \mathrm{E} 5$ & $8.0 E 5$ \\
\hline & $63 \mathrm{~B}$ & 77 & 80 & $3.08 \mathrm{E} 2$ & $1.00 \mathrm{E} 3$ & $1.20 \mathrm{E} 2$ & $1.30 \mathrm{E} 2$ \\
\hline & & 27 & 80 & $1.08 \mathrm{E} 2$ & $3.51 \mathrm{E} 2$ & $3.80 \mathrm{E} 2$ & $4.10 \mathrm{E} 2$ \\
\hline & & 9 & 80 & $3.6 \mathrm{E} 1$ & $1.17 \mathrm{E} 2$ & $2.00 E 3$ & $2.00 \mathrm{E} 3$ \\
\hline
\end{tabular}


TABLE A.1. (contd)

\begin{tabular}{|c|c|c|c|c|c|c|c|}
\hline Waste Type & Stream & $\begin{array}{c}\text { Containers/ } \\
1,500 \mathrm{MTU}\end{array}$ & $\begin{array}{l}\text { Container } \\
\text { Size, gal } \\
\end{array}$ & $\begin{array}{r}\text { Quantity } \\
\text { Waste } \\
\mathrm{ft}^{3}\end{array}$ & $\begin{array}{l}\text { Contained } \\
00 \mathrm{MTU} \\
\mathrm{kg} \\
\end{array}$ & $\begin{array}{c}\text { TRU } \\
\text { Content, } \\
\mathrm{nCi} / \mathrm{g} \\
\end{array}$ & $\begin{array}{c}\text { Container } \\
\text { Dose Rate, } \\
\quad \pi \mathrm{R} / \mathrm{hr} \\
\end{array}$ \\
\hline \multirow{3}{*}{$\begin{array}{l}\text { Filters (wood } \\
\text { framed) }\end{array}$} & \multirow[t]{3}{*}{$25 B$} & 153 & 80 & $5.38 \mathrm{E} 2$ & $1.99 \mathrm{E} 3$ & $3.70 \mathrm{E} 2$ & $1.30 \mathrm{E} 2$ \\
\hline & & 52 & 80 & $1.84 \mathrm{E} 2$ & $6.76 \mathrm{E} 2$ & $1.20 \mathrm{E} 3$ & $4.00 \mathrm{E} 2$ \\
\hline & & 12 & 80 & $2.85 \mathrm{E} 1$ & $1.56 \mathrm{E} 2$ & $3.00 \mathrm{E} 2$ & $2.30 \mathrm{E} 3$ \\
\hline \multirow{8}{*}{$\begin{array}{l}\text { GPT } \\
\text { (combustible) }\end{array}$} & \multirow[t]{3}{*}{27} & 128 & 55 & $9.60 \mathrm{E} 2$ & $2.69 \mathrm{E} 3$ & $2.20 \mathrm{E} 2$ & $1.50 \mathrm{E} 2$ \\
\hline & & 48 & 55 & $3.60 \mathrm{E} 2$ & $1.01 \mathrm{E} 3$ & $6.80 \mathrm{E} 2$ & 4.80E2 \\
\hline & & 42.4 & 55 & $3.18 \mathrm{E} 2$ & $8.90 \mathrm{E} 2$ & $4.50 E 3$ & $3.20 \mathrm{E} 3$ \\
\hline & \multirow[t]{3}{*}{53} & 94.5 & 55 & $6.21 E 2$ & $1.98 \mathrm{E} 3$ & $4.30 \mathrm{E} 3$ & $7.0 \mathrm{E}-1$ \\
\hline & & 137.6 & 55 & $9.05 \mathrm{E} 2$ & $2.89 \mathrm{E} 3$ & $6.0 \mathrm{E} 4$ & $1.0 \mathrm{E} 1$ \\
\hline & & 72 & 55 & $4.74 \mathrm{E} 2$ & $1.51 \mathrm{E} 3$ & $4.0 \mathrm{E} 5$ & $6.0 \mathrm{E} 1$ \\
\hline & \multirow[t]{2}{*}{65} & 36 & 55 & $2.40 \mathrm{E} 2$ & $7.56 \mathrm{E} 2$ & $2.20 \mathrm{E} 2$ & $4.80 \mathrm{E} 2$ \\
\hline & & 32 & 55 & $2.14 \mathrm{E} 2$ & $6.72 \mathrm{E} 2$ & $1.50 \mathrm{E} 3$ & $3.20 \mathrm{E} 3$ \\
\hline \multirow{8}{*}{$\begin{array}{l}\text { GPT (noncom- } \\
\text { bustible) }\end{array}$} & \multirow[t]{3}{*}{27} & 32 & 55 & $2=40 \mathrm{E} ?$ & $6.72 E ?$ & $2.20 \mathrm{E} 2$ & $1.50 \mathrm{E} ?$ \\
\hline & & 12 & 55 & $9.0 \mathrm{El}$ & $2.52 \mathrm{E} 2$ & $6.80 \mathrm{E} 2$ & $4.80 \mathrm{E} 2$ \\
\hline & & 10.6 & 55 & $8.0 \mathrm{E} 1$ & $2.23 E 2$ & $4.50 \mathrm{E} 3$ & $3.20 \mathrm{E} 3$ \\
\hline & \multirow[t]{3}{*}{53} & 23.6 & 55 & $1.55 \mathrm{E} 2$ & $4.96 \mathrm{E} 2$ & $4.30 E 3$ & $7.0 \mathrm{E}-1$ \\
\hline & & 34.4 & 55 & $2.26 \mathrm{E} 2$ & $7.22 \mathrm{E} 2$ & $6.0 \mathrm{E} 4$ & $1.0 \mathrm{E} 1$ \\
\hline & & 18 & 55 & $1.18 \mathrm{E} 2$ & $3.78 \mathrm{E} 2$ & $4.0 \mathrm{E} 5$ & $6.0 \mathrm{E} 1$ \\
\hline & \multirow[t]{2}{*}{65} & 9 & 55 & $6.0 \mathrm{E} 1$ & $1.89 \mathrm{E} 2$ & $2.20 \mathrm{E} 2$ & $4.80 \mathrm{E} 2$ \\
\hline & & 8 & 55 & $5.3 \mathrm{E} 1$ & $1.68 \mathrm{E} 2$ & $1.50 \mathrm{E} 3$ & $3.20 \mathrm{E} 3$ \\
\hline
\end{tabular}


TABLE A.1. (cont d)

\begin{tabular}{|c|c|c|c|c|c|c|c|}
\hline & & Containers/ & Container & $\begin{array}{r}\text { Quantity } \\
\text { Waste } \\
\end{array}$ & $\begin{array}{l}\text { Contained } \\
\text { D0 MTU }\end{array}$ & $\begin{array}{c}\text { TRU } \\
\text { content, }\end{array}$ & $\begin{array}{l}\text { Container } \\
\text { Dose Rate, }\end{array}$ \\
\hline Waste Type & Stream & $1,500 \mathrm{MTU}$ & Size, gal & $\mathrm{ft}^{3}$ & $\mathrm{~kg}$ & $\mathrm{nCi} / \mathrm{g}$ & $m R / h r$ \\
\hline SAC Waste & 23 & 21 & 600 & $4.26 \mathrm{E} 2$ & $1.66 \mathrm{E} 3$ & $4.50 \mathrm{E} 2$ & $2.60 \mathrm{E} 2$ \\
\hline & & 7 & 600 & $1.42 \mathrm{E} 2$ & $5.53 \mathrm{~F} ?$ & $8.90 \mathrm{~F} ?$ & $5.30 \mathrm{E} 2$ \\
\hline & & 2 & 600 & $4.1 E_{1}$ & $1.58 \mathrm{E} 2$ & $1.3 \mathrm{E} 4$ & $8.00 \mathrm{E} 3$ \\
\hline & & 2 & 600 & $4.1 \mathrm{~F} 1$ & $1.58 \mathrm{E} ?$ & $1.3 \mathrm{E} 5$ & $8.0 \mathrm{E} 4$ \\
\hline & 67 & 4 & 600 & $2.92 \mathrm{E} 2$ & $3.16 \mathrm{E} 2$ & $4.4 \mathrm{E} 3$ & $8.00 \mathrm{E} 3$ \\
\hline & & 1 & 600 & $7.3 \mathrm{E} 1$ & $7.9 \mathrm{E} 1$ & $4.4 \mathrm{E} 4$ & $8.0 \mathrm{E} 4$ \\
\hline Failed & 24 & 1 & 600 & $5.0 \mathrm{E} 1$ & $9.00 \mathrm{E} 2$ & $1.60 \mathrm{E} 2$ & $5.20 \mathrm{E} 2$ \\
\hline equipment & & 1 & 600 & $5.0 \mathrm{E} 1$ & $9.00 \mathrm{E} 2$ & $2.40 \mathrm{E} 3$ & $7.80 \mathrm{E} 3$ \\
\hline & & 1 & 600 & $5.0 \mathrm{E} 1$ & $9.00 \mathrm{E} 2$ & $2.4 \mathrm{E} 4$ & $8.0 E 4$ \\
\hline & $51 \mathrm{~A}$ & 2 & 55 & $1.4 \mathrm{El}$ & 4.00E2 & $6.80 \mathrm{E} 2$ & $1.0 \mathrm{E}-1$ \\
\hline & & 30 & 55 & $2.14 \mathrm{E} 2$ & $6.00 \mathrm{E} 3$ & $6.80 \mathrm{E} 3$ & $1.2 \mathrm{EO}$ \\
\hline & & 38 & 55 & $2.71 \mathrm{E} 2$ & $7.60 \mathrm{E} 3$ & $1.2 \mathrm{E} 5$ & $2.0 E 1$ \\
\hline & $51 B$ & 1 & 600 & $5.0 \mathrm{E} 1$ & $9.00 \mathrm{E} 2$ & $2.0 \mathrm{E} 3$ & $4.0 \mathrm{E}-1$ \\
\hline & & 3 & 600 & $1.50 \mathrm{E} 2$ & $2.70 \mathrm{E} 3$ & 1.?E4 & $1.7 \mathrm{EO}$ \\
\hline & 62 & 1 & 600 & $7.0 \mathrm{E} 1$ & $9.00 \mathrm{E} 2$ & $7.70 \mathrm{E} 2$ & $7.80 \mathrm{E} 3$ \\
\hline $\begin{array}{l}\text { Fluorinator } \\
\text { solids }\end{array}$ & 41 & 93 & 55 & $6.18 \mathrm{E} 2$ & $3.10 \mathrm{E} 4$ & $2.59 \mathrm{E} 2$ & $8.70 \mathrm{E} 2$ \\
\hline
\end{tabular}


A.1 REFERENCE

Darr, D. G. 1983. Waste Model Characteristics Study: Evaluation of Reprocessing Waste Estimates. D0E/3156/FR-01, Allied-General Nuclear Services, Barnwell, South Carolina. 
APPENDIX B

DETAILS OF THE ESTIMATION OF FINAL PROCESSED TRUW QUANTITIES 
APPENDIX B

DETAILS OF THE ESTIMATION OF FINAL PROCESSED TRUW OIIANTITIES

In Section 7, the TRIW treatment options are described and the final quantities of processed TRUW resulting from each option are presented. The assumptions leading to these quantities are described in more detail in this appendix.

B.1 GENERAL ASSUMPTIONS

Some of the general assumptions are listed below.

1. The internal container volumes and tare weights are provided in Table B.l.

TABLE B.1. Internal Container Volumes and Tare Weights

\begin{tabular}{|c|c|c|c|}
\hline $\begin{array}{l}\text { Nominal } \\
\text { Container Size }\end{array}$ & $\begin{array}{c}\text { Approx. Internal } \\
\text { Dimensions } \\
\text { dia } \times \text { ht, in. }\end{array}$ & $\begin{array}{l}\text { Internal } \\
\text { Volume, } m^{3} \\
\end{array}$ & $\begin{array}{c}\text { Tare } \\
\text { Weight, } \mathrm{kg} \\
\end{array}$ \\
\hline $55 \mathrm{gal}$ & $22.5 \times 34.0 \times 0.05$ & 0.208 & 31 \\
\hline $80 \mathrm{gal}$ & $27.3 \times 30.5 \times 0.05$ & 0.303 & 31 \\
\hline $160 \mathrm{ga}$ & $22.9 \times 90.0 \times 0.375$ & 0.606 & 430 \\
\hline $500 \mathrm{gat}$ & $44.0 \times 90.0 \times 0.375$ & 2.271 & 1,000 \\
\hline $53 \mathrm{ga} 1 \mathrm{HLW}$ & $12.3 \times 119.5 \times 0.25$ & 0.231 & 160 \\
\hline
\end{tabular}

2. The containers are loaded to 90 vol\% (in the case where the wastes are treated and repackaged).

3. The volume reduction factors are defined as initial volume divided by final volume.

B.2 OPTION 1 - NO TREATMENT

The weights, volumes, and number of containers of untreated and unpackaged TRIN are summarized in Section 5 . 


\section{B.3 OPTION 2 - MINIMUM TREATMENT}

In this TRUW treatment option, most of the wastes are compacted to reduce their volume. An in-can compaction process is assumed, with a container size of $160 \mathrm{gal}$.

The hulls and hardware are RH compacted in Rt batches. A compaction factor of 3.33 is assumed (Mckee et al. 1984).

Although Allied-General Nuclear Services (1978) specifies that failed equipment is not compactible, it is assumed in this study that some compaction can be obtained with high pressure compaction. The failed equipment is compacted in RH or $\mathrm{CH}$ batches. Size reduction is performed as required prior to compaction. A volume reduction factor of 1.67 (half that for hulls and hardware) is assumed for the failed equipment.

The filters are size reduced and compacted in $\mathrm{RH}$ or $\mathrm{CH}$ batches. A volume reduction factor of 4.0 is assumed for the filters.

Eighty wt\% of the GPT and $60 \mathrm{wt} \%$ of the SAC waste are combustible and are assumed to be compacted at a volume reduction factor of 4.0 . A volume reduction factor of 1.67 is assumed for the noncombustible portions of these wastes. These wastes are also compacted in $\mathrm{CH}$ and $\mathrm{RH}$ batches.

The fluorinator solids are left in their initial containers and are not treated.

The assumptions used to estimate the surface dose rate of the packaged waste are:

- Compaction provides negligible additional shielding.

- Surface dose is a weak function of geometry.

- Surface dose rate can be approximated by multiplying the initial surface dose rate by the ratio of initial packaged volume to the final packaged volume. 


\section{B.4 OPTION 3 - MINIMUM NUMBER OF PROCESSES AND PROOUCTS}

For this treatment option, all TRUW is immobilized in cement. The hulls and hardware are mixed with cement and placed back into 600-gal containers. It is assumed that the cement increases the untreated, unpackaged volume by 10 vol\%.

Premixed cement grout is poured over the failed equipment in a carbon steel container of the same size as the original stainless steel container. Because the failed equipment has substantial void space to accommodate an adequate amount of cement, it is assumed that there is no increase in volume. The cement is also assumed to reduce the surface dose by a factor of 4 .

The filters and GPT-SAC waste are shredded, combined with the fluorinator solids, and mixed with cement and water in $\mathrm{CH}$ or RH batches in an in-drum mixer. The following cement recipe is used (Schneider and Ledebrink 1983):

- $200 \mathrm{~kg}$ cement

- $80 \mathrm{~kg}$ water

- $20 \mathrm{~kg}$ salt $\left(\mathrm{NaNO}_{3}\right)$

- $40 \mathrm{~kg}$ soft waste (cellulose, filter media, wood filter frames)

- $60 \mathrm{~kg}$ hard waste (metal, fluorinator solids), for a total weight of $400 \mathrm{~kg}$ and a density of $2000 \mathrm{~kg} / \mathrm{m}^{3}$.

The cementing is assumed to reduce the surface dose of these wastes by a factor of 2. This factor is lower than that assumed for the cemented failed equipment because the shredded filters, GPT-SAC waste, and fluorinator solids have a smaller void volume.

\section{B.5 OPTION 4 - MAXIMUM VOLUME REOUCTION WITHOUT DECONTAMINATION}

In this option, the metals and ceramics are melted, the cellulose materials are incinerated, and the plastic and rubber are hot pressed. The processed waste is loaded at 90 vol\% in 160-gal containers. The densities of the melted TRUW are: 


\begin{tabular}{|c|c|c|}
\hline Waste Type & Density, $\mathrm{kg} / \mathrm{m}^{3}$ & $90 \%$ Density, $\mathrm{kg} / \mathrm{m}^{3}$ \\
\hline Hulls and hardware & 6,500 & 5,850 \\
\hline $\begin{array}{l}\text { Failed equipment, metal } \\
\text { filter frames, metallic } \\
\text { GPT-SAC waste }\end{array}$ & 7,800 & 7,080 \\
\hline $\begin{array}{l}\text { Melted ash, scrub residue } \\
\text { and filter media mixture }\end{array}$ & 2,300 & 2,070 \\
\hline Plastic and rubber & 1,200 & 1,080 \\
\hline
\end{tabular}

The hulls and hardware are melted to $90 \%$ of theoretical density. The weight of hardware is taken to be $17.4 \%$ of the total hulls and hardware weight (U.S. DOE 1979).

As in 0ption 2, the $\mathrm{CH}$ streams that could potentially become RH after treatment need to be identified. The criteria in option 2 are used again here:

$$
D_{0}\left(V_{0} / V_{f}\right)>200 m R / h r \rightarrow R H \text { waste }
$$

where

$$
\begin{aligned}
D_{0}= & \text { surface dose of original drum }(\mathrm{mR} / \mathrm{hr}) \\
V_{0}= & \text { volume of untreated and unpackaged waste based on drum } \\
& \text { volume }\left(\mathrm{m}^{3}\right) \\
V_{f}= & \text { volume of treated and packaged waste based on drum volume }\left(\mathrm{m}^{3}\right) .
\end{aligned}
$$

The failed equipment is separated into $\mathrm{CH}$ and $\mathrm{RH}$ batches. Some size reduction may be required prior to melting. The failed equipment is melted to $90 \%$ theoretical density in $\mathrm{CH}$ or RH batches.

The filters are $33.3 \mathrm{wt} \%$ frame, $33.3 \mathrm{wt} \%$ media, and $33.3 \mathrm{wt} \%$ adhesive and organics. It is assumed that the $\mathrm{CH} / \mathrm{RH}$ category of the metal frames does not change due to processing. The filters are shredded and burned in an incinerator, resulting in ash, media, and metals. The metals are removed and melted with the failed equipment to $90 \%$ of theoretical density in $\mathrm{CH}$ or RH metal 
batches. The ash, filter media, and scrubber solution residues are concentrated to $90 \%$ of theoretical density by incorporation into the metal melts. These melted residues are assumed to be RH.

The contamination is assumed to be equally distributed for the GPT-SAC waste. The GPT-SAC waste is sorted by material type and the metals are melted in $\mathrm{CH}$ or RH batches. The rubber and plastics are hot pressed to $90 \%$ theoretical density in $\mathrm{RH}$ or $\mathrm{CH}$ batches in a low-temperature hot press and the cellulosic materials are burned. From the above contamination estimates, nearly all the ash and scrubber residues from the GPT are RH; therefore all the ash and scrubber residues are melted to $90 \%$ of theoretical density as RH.

For incineration,

$1 \mathrm{~kg}$ combustibles $+0.03 \mathrm{~kg}$ of ash $+5.7 \mathrm{E}-4 \mathrm{~s}^{3}$ concentrated scrubber solution.

It is assumed that the scrubber solution contains the following salt concentration (U.S. DOE 1979:4.4.6). (These equations describe the assumptions made; they are not chemically balanced.)

$$
\begin{array}{lll}
\mathrm{NaHCO}_{3} & 0.7 \underline{\mathrm{M}} & \begin{array}{l}
\mathrm{NaHCO}_{3}+\mathrm{Na}_{2} \mathrm{O}+\mathrm{H}_{2} \mathrm{CO}_{3} \\
\mathrm{Na}_{2} \mathrm{SO}_{3} / \mathrm{Na}_{2} \mathrm{SO}_{4}
\end{array} \\
\begin{array}{ll}
0.06 \underline{\mathrm{M}} \\
\text { particles }
\end{array} & \begin{array}{l}
\mathrm{aNa}_{2} \mathrm{SO}_{3}+\mathrm{bNa}_{2} \mathrm{SO}_{4}+(\mathrm{a}+\mathrm{b}) \mathrm{Na}_{2} \mathrm{SO}_{3} \\
\mathrm{Na}_{2} \mathrm{SO}_{3}+\mathrm{Na}_{2} \mathrm{O}+\mathrm{SO}_{3}
\end{array}
\end{array}
$$

\begin{tabular}{|c|c|c|}
\hline & Moles & Weight, g \\
\hline $\mathrm{Na}_{2} \mathrm{O}$ & 0.41 & 25.4 \\
\hline $\mathrm{SO}_{3}$ & 0.06 & 4.8 \\
\hline \multirow[t]{2}{*}{ Particles } & -- & 0.2 \\
\hline & & 30.4 \\
\hline
\end{tabular}

The residue composition from $1 \mathrm{~L}$ of concentrated scrubber solution is: 
Therefore, $1 \mathrm{~m}^{3}$ of concentrated scrubber solution is equivalent to $30.4 \mathrm{~kg}$ of concentrated scrubber residues, or $1 \mathrm{~kg}$ of combustibles (without PVC) is incinerated to produce $0.0173 \mathrm{~kg}$ of scrubber residues.

\section{B.6 OPTION 5 - MAXIMUM VOLUME REDUCTION WITH DECCNTAMINATION}

The processing emphasis of this option is on decontamination. The LLW resulting from the decontamination is packaged in 160-gal containers. In Suboption $5 \mathrm{~A}$, the solids removed from the hull decontamination are incorporated into HLW glass, and the diameter of the HLW canister is increased to accommodate the additional HLW without increasing the number of HLW canisters. In Suboption 5B, the solids from the hull decontamination solution are hot pressed. Secondary wastes from other decontamination operations are also incorporated in HLW glass. These latter quantities are small; thus it is assumed that this small quantity of HLW (a 2.8\% ircrease in the amount of HLW glass formed) can be added to the existing HLW without requiring an increase in the canister size or in the number of HLW canisters. The HLW glass is assumed to have a density of $2,700 \mathrm{~kg} / \mathrm{m}^{3}$.

The hulls are cryogenically cracked prior to decontamination. A packing density of $1,360 \mathrm{~kg} / \mathrm{m}^{3}$ is assumed for the cracked hulls. During decontamination, 7 wto of the hulls is removed. It is assumed that half of the material removed is $\mathrm{Zr}$ and half is $\mathrm{ZrO}_{2}$. The hull decontamination slurry contains $\mathrm{Zr}$, $\mathrm{ZrO}_{2}$, and $\mathrm{Al}_{2} \mathrm{O}_{3}$ abrasives. The volume of alumina in the decontamination slurry is $5 \mathrm{~cm}^{3} / \mathrm{kg}$ of decontaminated hulls. The density of the alumina is $1,800 \mathrm{~kg} / \mathrm{m}^{3}$. The water in the decontamination slurry is then boiled off. In Option 5A, the solids from the decontamination slurry ( $\mathrm{Zr}, \mathrm{ZrO}{ }_{2}, \mathrm{Al}_{2} \mathrm{O}_{3}$ ) are loaded into $\mathrm{HLW}$ glass at $20 \mathrm{wt} \%$. In Option $5 \mathrm{~B}$ the $\mathrm{Zr} / \mathrm{ZrO}_{2}$ solids are hot pressed to $90 \%$ theoretical density in a high-temperature hot press. The density of $\mathrm{Zr}$ is $6,450 \mathrm{~kg} / \mathrm{m}^{3}$, and the density of $Z \mathrm{rO}_{2}$ is $5,600 \mathrm{~kg} / \mathrm{m}^{3}$.

The fuel hardware, failed equipment, metal filter frames, and metallic GPT-SAC waste are decontaminated by vibratory finishing. It is assumed that during decontamination, $50 \mathrm{~g}$ of metal fines are ramoved per $m^{2}$ of decontaminated surface area, and that the decontamination solution contains $0.35 \mathrm{~kg}$ of $\mathrm{NaOH}$ per $\mathrm{m}^{2}$ of decontaminated surface area. Ir estimating the surface areas 
of the metals to be decontaminated, it is assumed that the metals have a density of $7,800 \mathrm{~kg} / \mathrm{m}^{3}$; that the failed equipment has an average thickness of $0.0064 \mathrm{~m}$ (1/4 in.); and that the fuel hardware, metal filter frames, and metallic GPT-SAC waste have an average thickness of $0.0032 \mathrm{~m}$ (1/8 in.). The decontamination slurries contain $\mathrm{Fe}$ and $\mathrm{NaOH}$. After the water is removed from the decontamination slurries, the $\mathrm{Fe}$ is converted to $\mathrm{Fe}_{2} \mathrm{O}_{3}$. The $\mathrm{Fe}_{2} \mathrm{O}_{3}$ is loaded in HLW glass at $33 \mathrm{wt} \%$. It is assumed that the addition of NaOH replaces the $\mathrm{Na}$ in the glass frit additive to the HLW glass mixture and does not increase the HLW volume.

After decontamination the packing density of the low-level hardware is assumed to be $1,000 \mathrm{~kg} / \mathrm{m}^{3}$.

Thirty wt\% (or vol\%) of the failed equipment is assumed to be nondecontaminable and is therefore compacted. A volume reduction factor of 1.67 is assumed, as in option 2. The decontaminable failed equipment is size reduced prior to decontamination. This size reduction gives a volume reduction factor of 2 .

The filters are shredded and incinerated to burn the wood and adhesive. The metal frames are removed from the ash and media and decontaminated by vibratory finishing. The decontaminated metal frames are assumed to have a density similar to that of cut-up glove boxes $\left(530 \mathrm{~kg} / \mathrm{m}^{3}\right)$. The decontamination solution residues (containing iron oxide and caustic), ash, and scrubber solution solids (from incineration; their composition is the same as in option 4) are loaded into HLW glass at $33 \mathrm{wt} \%$. The filter media are mixed with the total production of HLW glass without the use of incremental additives.

The GPT-SAC waste is sorted by material type. Thirty wt\% of the metals are considered nondecontaminable. These metals are compacted with the nondecontaminable failed equipment. The nondecontaminable GPT-SAC waste is assumed to be compacted to the same density as the GPT-SAC waste $\left(1,350 \mathrm{~kg} / \mathrm{m}^{3}\right)$ in option 2. The compacted waste is packaged in 160-gal containers.

The plastic and rubber is 33 wto of the combustible portion of the GPT-SAC waste. The plastic and rubber are decontaminated by vibratory finishing, as are the metals. It is assumed that the plastic and rubber have an average 
thickness of $0.5 \mathrm{~mm}(0.02 \mathrm{in.})$ and that the decontamination solution contains $0.35 \mathrm{~kg} \mathrm{NaOH}$ for every $\mathrm{m}^{2}$ of plastic and rubber decontaminated. It is assumed that the $L L W$ plastic and rubber is packaged at the same density $\left(105 \mathrm{~kg} / \mathrm{m}^{3}\right)$ as the GPT-SAC waste in Option 1.

The cellulosic materials in GPT-SAC waste are incinerated to ash. The scrubber solution from the incineration is decontaminated and the low-level liquids and scrubber solution salt are cemented using the following recipe:

\section{$6.4 \mathrm{wt} \% \mathrm{NaCl}$ and other salts}

\section{3 wto water}

56.3 wt\% cement

density $1,820 \mathrm{~kg} / \mathrm{m}^{3}$.

The cementation TRIJW is packaged in 55-gal drums. The solids $\left(\mathrm{Fe}(\mathrm{OH})_{3}\right)$ from the decontamination of the scrubber solution are loaded into HLW glass with the ash at 33 wt $\%$.

The decontaminable metallic GPT-SAC waste (70 wt $\%$ of the metals) is decontaminated in the same way as the decontaminable failed equipment. The lowlevel metallic GPT-SAC waste is assumed to have the same density $\left(105 \mathrm{~kg} / \mathrm{m}^{3}\right)$ as the untreated GPT-SAC waste. The nondecontaminable waste is compacted to the same density $\left(1,350 \mathrm{~kg} / \mathrm{m}^{3}\right)$ as the compacted GPT-SAC waste in Option ?.

The TRU fluorinator solids are converted to LLW by blending them with other non-TRU fluorinator solids.

\section{R.7 OPTION 6 - NONCOMBUSTIBLE WASTE FORMS}

The hulls and hardware and failed equipment are melted as in 0ption 4. The SAC waste is sorted into noncombustibles and combustibles. The noncombustible GPT-SAC waste (which is primarily metal) is treated in the same manner as in Option 4. The combustible GPT-SAC waste and filters are shredded and hurned. The ash, media, filter metal, and scrubber residue solids are cemented. Ouantities converted from $\mathrm{CH}$ to $\mathrm{RH}$ waste are estimated as before.

The incineration of $1 \mathrm{~kg}$ of combustibles produces $0.03 \mathrm{~kg}$ of ash and $5.7 \mathrm{E}-4 \mathrm{~m}^{3}$ of concentrated scrubber solution. Therefore, the incineration of $\mathrm{l} \mathrm{kg}$ of wood filters and athesives is equivalent to $0.0173 \mathrm{~kg}$ of solids (see 
Option 4). The scrubber solution from the incineration of GPT-SAC waste containing PVC will also contain NaCl. One-third of the combustible GPT-SAC waste is plastic and rubber (Darr 1983). PVC is 30 wt\% of the plastic and rubber (Allied-General Nuclear Services 1978:E-2) where $57 \mathrm{wt} \%$ of the PVC is taken to be $\mathrm{Cl}^{-}$(which is converted to $\mathrm{NaCl}$ ). Therefore, burning $1 \mathrm{~kg}$ of the combustible GPT-SAC waste results in $0.094 \mathrm{~kg}$ of $\mathrm{NaCl}$ in the scrubber solution.

The following cement recipe is used:

50 wt\% cement

$20 w t \%$ water

$5 \mathrm{wt} \%$ salt ( $\mathrm{NaCl})$

10 wt\% soft waste (media, ash)

15 wt\% hard waste (metals, fluorinator solids)

density $2,000 \mathrm{~kg} / \mathrm{m}^{3}$.

The fluorinator solids are cemented at $30 \mathrm{wt} \%$ waste loading. It is assumed that the cementing of the fluorinator solids will result in LLW, which is packaged in 160-gal containers.

\section{B.8 REFERENCES}

Allied-General Nuclear Services. 1978. Studies and Research Concerning BNFP-Storage and Handling of Wastes from Uranium Fuel Processing Alternatives. ÁĞS-1040-3.3-34, Allied-Genera? Nuclear Services, Rarnwell, South Carolina.

Darr, D. G. 1983. Waste Model Characteristics Study: Evaluation of Reprocessing Waste Estimates. D0E/3156/RF-01, Allied-General NucTear Services, Barnwell, South Carolina.

Mckee, R. W., L. L. Clark, P. M. Daling, J. F. Nesbitt, and J. L. Swanson. 1984. "Economic Analysis of Waste Management System Alternatives for Reprocessing Wastes." Waste Management 1984, pp. 383-393. University of Arizona, Tucson.

Schneider, V. W., and F. W. Ledebrink. 1983. "Cementation of TRU-Hastes by a New Process, Properties of the Products." Presented at the Second International Symposium on Ceramics in Nuclear Waste Management, Chicago, Illinois, April 1983.

U.S. Department of Energy. 1979. Technology for Commercial Radioactive Waste Management. DOE/ET-0028, Volume 2 of $5,11.5$. DOE, Washington, D.C. 


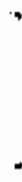


APPENDIX C

ADOITIONAL INFORMATION ON REGULATIONS AND TRUW OEFINITIONS 
APPENDIX C

ADDITIONAL INFORMATION ON REGULATIONS AND TRUW DEFINITIONS

\section{C.1 REGULATIONS}

The EPA regulation 40 CFR 190 (U.S. EPA 1984a) is the basic federal regulation regarding environmental radiation protection for the operation of uranium nuclear fuel cycle facilities. This regulation states that the dose equivalent to any member of the public for expected performance of operations in the nuclear fuel cycle sha11 not exceed $75 \mathrm{mrem} / \mathrm{yr}$ to the thyroid or 25 $\mathrm{mrem} / \mathrm{yr}$ to the whole body or to any other organ. If an individual is exposed to radiation sources from two or more activities in the nuclear fuel cycle, any one activity can expose the individual to only a prorated fraction of this total dose. The EPA has included these numerical limits in Subpart A of their proposed regulation 40 CFR 191 (II.S. EPA 1985) for application to expected performance in the operational aspects of waste management (i.e., treatment, storage, and filling and pre-sealing of a repository). The limits are not intended to apply to unexpected performance, to the post-closure disposal time period, or to transportation.

Guidance for ALARA exposure for operating nuclear power reactors is given in Appendix I of 10 CFR 50 (U.S. NRC 1984a). This guidance, which is not specified as being applicable to nonreactor facilities, suggests 5 to 10 $\mathrm{mrem} / \mathrm{yr}$ for each of several exposure pathways. Regulation 10 CFR 72 (11.5. NRC 1984b) for offsite spent fuel storage facilities specifies an ALARA-based dose limit of $5 \mathrm{mrem} / \mathrm{yr}$ to members of the public.

The basic regulations for radiation protection of the public during transportation are covered in 10 CFR 20 (1I.S. NRC 1984C). Specific regulations have been issued by the DOT in 49 CFR 171-178 (U.S. DOT 1984) and by the NRC in 10 CFR 71 (U.S. NRC 1984d). The regulations specify packaging requirements, radiation limits, labeling requirements, handing procedures, and security procedures. Containment is the principal performance requirement for transportation of TRUW, and it is generally provided by the outer transportation packaging (i.e., the cask for RH TRIII, and the TRIJPACT packaging for 
$\mathrm{CH}$ TRUW). The outer packaging must maintain containnent under accident conditions (as well as normal conditions). The transportation packaging must endure severe physical tests without loss of containment. The most important of these tests are, in sequence: impact, puncture, fire, and submersion in water. These tests are sufficiently stringent that they encompass the performance needs for all but the most severe accidents, for which the probability of occurrence is very low.

For shipments containing more than $20 \mathrm{Ci}$ of plutonium (which would include much of the TRUW), the NRC regulations require that the packaging system (i.e., outer cask and inner packagings such as the canister or an overpack of the canister within the outer packaging) must retain two levels of containment during test conditions. However, the NRC regulations do allow for the exemption of some materials on a case-by-case basis (which currently includes spent fuel). Potential exemption from this requirement would probably depend on the expected releases of waste materials during severe accidents, which in turn would be related to the waste form characteristics in combination with the canister, the liners/spacers inside the transportation packaging, and the transportation packaging. In any case, the waste canister can be less rugged than the cask, which will absorb nearly all of the accident environment. It is assumed in this study that the necessary level of containment for transporting the wastes is provided by the transportation packagings and the canisters, in combination with reusable liners/spacers within the transportation packagings.

\section{C.2 DEFINITION OF TRLW}

The following definition of TRUW is given in the fifth working draft of proposed 40 CFR 191:

Transuranic wastes, as used in this part, metans wastes containing more than 100 nanocuries of alpha-emitting transuranic isotopes, with half-lives greater than 20 years, per gram of waste except for: (1) high-level radioactive wastes; (2) wastes that the Department [DOE] has determined, with the concurrence of the Administrator [of EPA], do not need the degree of isolation needed by this Part; or

(3) wastes that the Comission [NRC] has approved for disposal on a case-by-case basis in accordance with 10 CFR 61. 
This definition generally includes all of the actinides with atomic numbers higher than that of uranium (92) that are present in significant quantities in spent nuclear fuel, with the exclusion of ${ }^{24} 1_{\mathrm{Pu}}$ and ${ }^{244} \mathrm{Cm}$. It excludes all alpha-emitting actinides lighter than uranium (isotopes of protactinium, thorium, actinium, radium, francium, radon, astatine, polonium, and bismuth), even though some of these are present in important quantities in spent fuel and some are potentially important dose contributors in waste management.

The NRC has yet to specify a definition of TRUW to be used for waste management purposes. However, the NRC has identified TRUW as waste containing greater than $100 \mathrm{nC} i$ of transuranium elements per gram of waste, with transuranium elements defined as those having atomic numbers greater than 92 . They also state that transuranium elements include uranium and plutonium.

The NRC has defined HLW and LLW in 10 CFR 60 (U.S. NRC 1984e) and 10 CFR 61 (U.S. NRC 1984f), respectively, and TRUW must fall somewhere between these definitions. HLW is defined by its source: "(1) irradiated reactor fuel, (2) liquid wastes resulting from operation of the first cycle solvent extraction system, or equivalent, and the concentrated wastes from subsequent extraction cycles, or equivalent, in a facility for reprocessing irradiated reactor fuel, and (3) solids into which such liquid wastes have been converted." Lowlevel wastes are those "that are acceptable for disposal in a land disposal facility." Low-level waste is "waste that is radioactive waste not classified as high-level radioactive waste, transuranic waste, spent nuclear fuel, or byproduct material." Wastes that are not acceptable for shallow land burial are then identified in 10 CFR 61 by specifying maximum concentrations of TRU nuclides with half-lives greater than 5 years of $100 \mathrm{nCi} / \mathrm{g}$, the maximum amount of $241_{\mathrm{Pu}}$ of $3,500 \mathrm{nCi} / \mathrm{g}$, and the maximum amount of ${ }^{242} \mathrm{Cm}$ of $20,000 \mathrm{nCi} / \mathrm{g}$ of waste. (The correction for the beta-emitter $241_{\mathrm{Pu}}$ allows for the alpha decay of its daughters; the correction for the short-lived alpha-emitter ${ }^{242} \mathrm{Cm}$ allows for decay of its long-lived ${ }^{241}$ Pu alpha-emitting daughters.) Numerical limits are also given for non-TRU radionuclides.

The Waste Acceptance Criteria for WIPP (Westinghouse Electric Company 1984) also include $233 \mathrm{U}$ as a transuranic nuclide. The general definition in DOE Order 5820 (draft February 6, 1984) (U.S. DOE 1984) is slightly different; 
it states that transuranic waste is "radioactive waste that at the end of the institutional control periods is contaminated with alpha-emitting transuranic radionuclides with half-lives greater than 20 years and concentrations greater than $100 \mathrm{nCi} / \mathrm{g} . "$

All of these definitions are similar. For this study, the definition given in the fifth working draft of EPA's 40 CFR 191 regulation is used.

\section{C.3 WASTE FORM REQUIREMENTS}

Waste form requirements for TRUW have yet to be specified. The NRC has requirements for releases from the engineered barriers (including waste forms) for geologic disposal of HLW and TRUW in 10 CFR 60 and for LLW forms for shallow-land burial in 10 CFR 61. The DOE has requirements for defense TRUW to be disposed of at WIPP (Westinghouse Electric Company 1984). The EPA has only some proposed general requirements for release of radionuclides from TRUW to the accessible environment in the fourth and fifth working drafts of 40 CFR 191 (1).S. EPA 1984b, 1985). The requirements that may be related to waste forms in these regulations are given in Table $C .1$ and are discussed in Section 4 .

The release limits from a deep geologic (basalt) repository to the accessible environment for spent fuel, HLW, and/or TRUW proposed by the EPA in the fourth working draft of 40 CFR 191 are given in Table C.2. 


\section{TABLE C.1. Regulations/Criteria Related to TRUW Form/Container Requirements}

\begin{tabular}{|c|c|c|c|}
\hline No. & Characteristic & 10 CFR $6(3, H L W$ and TRUH & $\begin{array}{c}10 \text { CFR 61, LLW } \\
\text { (generally for classes Risc) }\end{array}$ \\
\hline 1 & Canister & $\begin{array}{l}\text { Ketrievable within } 50 \text { years; } \\
\text { sed led; modstain contain- } \\
\text { ment during transpurtation; } \\
\text { pass transporlation type } \\
\text { tests; emplacement, } \\
\text { retrieval }\end{array}$ & 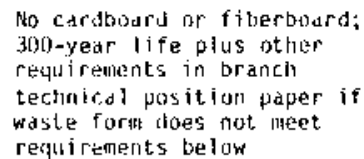 \\
\hline
\end{tabular}

2 Packdye characteristics Chenfical-physical-nuclear characteristics conpatible year life for package

3 patkalje considerations

Solubility; oxidizing/

sion; hydriding, gas gener-

ation; thernal stress;

radiolysis; retardation;

leaching; fire/explosion

hazards; sylleryistic

4 Waste form

Solid; particulates to

Solid; particulates

dispersible

\section{: Ilitinstitijity

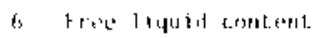

Must be nonconbust int unless showri that fire will not. fomilumaist safety

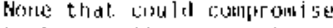
isolation (in pickalye

7 Explosives content
Free-standiny monoliths for

Class A solidified liquids

only); other requirements

in branch technical posi-

position paper (see item

18 and item 4 . Column 7 )

40 CFR 191, HLW \& TRUW

(3).52. 11 f xeiutht per Aass 55.1 ; heeds louble the minitum amount absurberit

Not readily capable of reaction

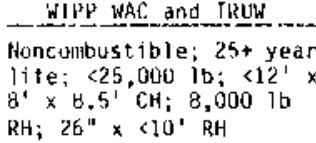
8. $\times \mathrm{B}^{\circ} \mathrm{CH}_{\mathrm{i}} 8,000$

$y / c a n$ must be $<10$ um must be $<200$ un parti cles; sludges OK if corrosion protection: no corrosive materials

Compostte bases froin and WIPP WAC

Noncunbustible; $25+$ year life; 300 year life with poor waste forms ise "other" beiow); pass requi rements; for CH TRUW, $412^{\prime} \times 8^{\prime} \times 8.5^{\prime}$ and $<25,000$ 1b; for RH TRIU $<8,000$ tb; maintain containfment during transportation, emplacement,

retrieval

Chemical-physical-nuclear characteristics compatible with repository

Solubility; oxidizing/ reducing patential corrosion; hydridiny; gas generation; thermal loads and effects; stress; radiolysis: retardation of radionuclide migration: leaching; fire/explosion interactions

Resistant to radtation (1EB kad Y): resistant to biodegradation test. resistant to leaching: resistant to breakdown from water imnersion; resistant to breakdown test; compressive strength $>50$ psi; not
dispersible; <l\%/can must be $<10$ ur particles

OK but must be in noncombisustible canister and labeled

Must be nonconbustiole will not compromise safet Peneme in can; sluddes ok if container is corrosun protected

$<.5$ wtz; neetd double the minimuin alnount absorbent; 5 ludges ok if contalner is corrosion

None al lowed

None allowed 
TABLE C.1. (contd)

\begin{tabular}{|c|c|c|c|}
\hline No. & Characteristlc & li] CFR SO, HLW and TRUW & $\begin{array}{c}10 \mathrm{CFR} 61, \mathrm{LLW} \\
\text { (generally for classes B\&C) }\end{array}$ \\
\hline 8 & Toxic gases, vapors & & $\begin{array}{l}\text { None allowed, except for } \\
\text { gaseous radianuclites }\end{array}$ \\
\hline 9 & $\begin{array}{l}\text { Pyrophoric materíal } \\
\text { content }\end{array}$ & $\begin{array}{l}\text { Must not contain amounts } \\
\text { that could compromise } \\
\text { waste f folation }\end{array}$ & None allowed \\
\hline 10 & Gaseous waste & & $\begin{array}{l}\text { Pressure }<1,5 \text { atm at } 20^{\circ} \mathrm{C} \text { : } \\
\text { cloo } \mathrm{Cy} / \text { container of } \\
\text { gaseous radionuclides }\end{array}$ \\
\hline
\end{tabular}

11 Gas generation

12 Hazardous, biologically pathoyenic, infectious

in

13 Structural stability

14 Yotd spaces

15 Release rate from repository to

From engineered barrier. <1E-5/yr of 1000 year inventory; not applicable $<.1 \%$ of calculated total

16 Dose to public

1) Identiffcation

Reduce nonradiological hazard as low as praccicable; see also branch for LLW belou

\section{Form or container must be} disposal environment; see
branch pasition paper below

Reduce to extent practicaj
Composite bases trom
10 CFR 61 . WIPP WAC and TRUW No toxic materials or poisuns $A, B$ unless
Mone if nonradioactive: radionuclides <ig and must be dispersed mately associated with radianuclides, and then radionucl ides must be

Pressure < 1.5 atm at Pressure $<1.5 \mathrm{atgm}$ at
$20^{\circ} \mathrm{C} ; 100 \mathrm{~kg} / \mathrm{m}^{3}$ in other containers

$<100-220 \mathrm{~kg} / \mathrm{m}^{3}$ organtc in waste; $510 \mathrm{moles} / \mathrm{m}^{3}$ other contalners 55 gal drums; $<100 \mathrm{~kg} / \mathrm{m}^{3}$ in other containers structurally stable in

In 10,000 years, release values less than in table with probability c0.1; alpha radionucildes to dquifer in 1.000 years
strali be $15 \mathrm{pCi} / L$

$<25 / 75 / 25$ airenar $/$ yr ALAKA; $<4$ mrens/yr $\beta+$ from radionuclides in aquifer rate by all mechantsins hazard to as low as prac posiction paper requireposition paper require

Form or canisters nust be structurally stable in disposal enviranment; see a)so branch position
paper for $\mathrm{LLH}$ beiow

Rertuce to extent practical

Probability $<0.1$ that release values in 10,000 years will exceed those in EPA table; aipha radionuclides to aquifer in 1000 years shall be < 15 $\mathrm{pCi} / 1$; from eng ineered
barrter < LE-5/yr of 1000 applicable to radionucalculated total release rate

$<25 / 75 / 25 \mathrm{mrem} / \mathrm{yr}$ ALARA; <4 mrem/yr B + from radionuclides in aquifer

Permanent and unique
Reduce nonradioloyical year inventory; not 
10 CFR 61. HLW No. Characteristic 10 CFR 60, HLW and FRUW 18 other
10 CFR 61 .
nerally for Classes B\&C) Branch technical position paper (U.S. RRC 1983) gives details on waste form

requirements: conpressive strength $>50$ psi per ASTM

Expose to al +8 tests:

- Resistant to bod

tion test (ASTM G2Is22)

- Resistant to 90 day leak

test (leachabilifty index

$>6$ per ANS 26.1

- Resistant to immersion

90 days

- Resistant to thermal

cycing $+60^{\circ}$ to $-40^{\circ} \mathrm{C}$

Section

- Destructive

ve analysis to

assure homogeneity

300-year LLL

container with $1201 \mathrm{~b} / \mathrm{ft}^{3}$

overburcen

- Resistant to $1 E+8$ Rad

- Resistant to blode.

gradation test as above

cycling as abovernal

- Positive steel

- Contents inspectable

- Passive vent

- Withstand $3 \mathrm{G}$ lifting load
Composite Bases from and WIPP WAC

For ILW forms, compressive strength 450 psi after

- Expose to $1 E+8$ Rad Resistant to biode- Resistant to 90

leach test (leacha billity index $>6$ per ANS 16.1$)$

- Resistant to immersion 90 days

- Resistant to thermal
cycling $60^{\circ}$ to $-40^{\circ} \mathrm{C}$ Destructive analys is to assure homogene ty

oritar

conta1ner - Strength with $120 \mathrm{~b} / \mathrm{ft}^{3}$ overburden - Resistant to $1 \mathrm{E}+9$ Rad - Resistant to themal cycling as above

- Resistant to biode-

gradation test as above

- Positive steel

- Contents inspectable

- Withstand 3

glifting

$\mathrm{CH}<3.5 \mathrm{~W} / \mathrm{m}^{3}$

RH $<300 \mathrm{~W} / \mathrm{can}$;

$<200 \mathrm{~g}$ fissile/55-gal

drum: Dose $\mathrm{CH}<200 \mathrm{mrem} /$ hr: Dose RH <100 rem/hr: 


\section{TABLE C.2. Release Limits for Containment Requi rements (cumulative releases to the} accessible environment for 10,000 years after disposal) (U.S. EPA 1985)

\begin{tabular}{lr} 
Radionuclide & $\begin{array}{c}\text { Release limit } \\
\text { (curies) }\end{array}$ \\
\cline { 2 - 2 } Americium-24] & 100 \\
Americium-243 & 100 \\
Carbon-14 & 100 \\
Cesium-335 & 1,000 \\
Cesium-137 & 1,000 \\
Neptunium-237 & 100 \\
P1utonium-238 & 100 \\
Plutoni um-239 & 100 \\
Plutoni um-240 & 100
\end{tabular}

Radi onuclide
Plutoni um-242
Radi um-226
Stronti um- 90
Technetium- 99
Tin-126
Any other alpha-emitting
radionuclide
Any other radi onuclide that does
not emit al pha particles

Release Limit

not emit alpha particles

(curies)

100

100

1,000

10,000

1,000

100

1,000

Note 1: The Release Limits in Table C.2 apply to the amount of wastes in any one of the following:

(a) an amount of spent nuclear fuel containing 1,000 metric tons of heavy metal (MTHM);

(b) the high-level wastes, as defined by 191,02 (e)(1). generated from each 1,000 MiHM; mission as high-levei waste in accordance with $191.02(e)(2)$ :

(d) each 1,000,000 curies of other radionuclides (gamma- or beta-emitters with half-lives greater than 100 years or any alpha-emitters) that are identified by the Commission as high-level waste in accordance with 191.02 (e)(2); or

(e) an amount of transuranic wastes, as defined by $191.02(f)$, containing one million curies of alpha-emitting transuranic radionuclides. To develop Release Ligits for a particular disposal system, the quantities in Table C.2 shall be adjusted for the amount of wastes included in the disposal system. For example:

(a) If a particular disposal system contained the high-level wastes from $50,000 \mathrm{MTHM}$, the release limits for that system would be the

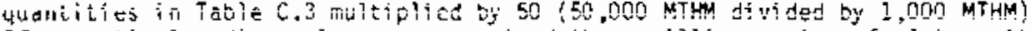

(b) If a particular disposal system contai ned three million curies of alpha-emitting transuranic wastes, the Release Limits for that

(c) If a particular disposal system contained both the high-level wastes from 50,000 MTHM and 5 mi lifion curies of alpha-emitting transuranic wastes, the reiease limits for that system would be the quantities in Table C.3 multiplied by 55 :

$$
\frac{50,000 \text { MTHM }}{1,000 \text { MTHM }}+\frac{5,000,000 \text { curies TRU }}{1,000,000 \text { curies TRU }}=55
$$

Note 2: In cases where a mixture of radionuclides is projected to be released, the limiting values shall be determined as follows: for each radionuclide in the mixture, determine the ratio between the cumulative release quantity projected over 10,000 years and the 1 imit excent one.

For example, if radionuclides $A, B$, and $C$ are projected to be released in amounts $Q_{a}, Q_{b}$, and $Q_{C}$, and if the applicable Release

$L i m i t s$ are $R L_{c}$, $R L_{D}$, and $R L_{r}$, then the cumulative releases over 10,000 years shall be 11 mited so that the following reiationship exists:

$$
\frac{Q_{a}}{R L_{a}}+\frac{Q_{b}}{R L_{b}}+\frac{Q_{c}}{R L_{c}} \leq 1
$$




\section{1 REFERENCES}

U.S. Department of Energy. 1984. Radioactive Waste Management, DOE Draft Order 5820, February 6, 1984. U.S. DOE, Washington, D.C.

U.S. Department of Transportation. 1984. Code of Federal Regulations, Title 49, Transportation (Subchapter $C$ - Hazardous Material Regulations); Part 171, General Information, Regulations and Definitions; Part 172, Hazardous Materials Table and Hazardous Materials Communications Regulations; Part 173, Shippers General Requirements for Shipments and Packagings; Part 174, Carriage by Rail; Part 177, Carriage by Public Highway; Part 178, Shipping Container Specifications, Revised January 1, 1982. 1J.S. DOT, Washington, D.C.

U.S. Environmental Protection Agency. 1984a. Code of Federal Regulations, Title 40, Protection of Environment; Part 190, Environmental Protection Standards for Nuclear Power Operations. Revised January 1, 1982. U.S. EPA, Washington, D.C.

U.S. Environmental Protection Agency, 1984b. Fourth Working Draft. Code of Federal Regulations, Title 40, Protection of Environment; Part 191, Environmental Protection Standards for Management and Disposal of Spent Nuclear Fue1, High-Level and Transuranic Radioactive Wastes. ApriT 17, 1985. J.S. Public Document Room, Washington, D.C.

1.5. Environmental Protection Agency. 1985. Fifth Working Draft. Code of Federal Regulations, Title 40, Protection of Environment; Part 191, Environmental Radiation Protection Standards for Management and Disposal of Spent Nuclear Fuel, High-Level and Transuranic Radioactive Wastes. March 21, 1985. U.S. Public Document Room, Washington, D.C.

U.S. Nuclear Regulatory Commission. 1983. Low-Level Licensing Branch Technical Position on Radioactive Waste Classification. May 1983, Revision D. U.S. NRC, Washington, D.C.

U.S. Nuclear Regulatory Commission. 1984a. Code of Federal Regulations, Title 10, Energy; Part 50, Domestic Licensing of Production and litilization Facilities. U.S. NRC, Washington, D.C.

U.S. Nuclear Regulatory Commission. 1984b. Code of Federal Regulations, Title 10, Energy; Part 72, Licensing Requirements for the Storage of Spent Fuel in an Independent Spent Fuel Storage Installation (ISFSI). U.S. NRC, Washington, D.C.

U.S. Nuclear Regulatory Comrission. 1984c. Code of Federal Regulations, Title 10, Energy; Part 20, Standards for Protection Against Radiation. U.S. NRC, Washington, D.C. 
U.S. Nuclear Regulatory Commission. 1984d. Code of Federal Regulations, Title 10, Energy; Part 71, Packaging and Transportation of Radioactive Material. U.S. Federal Register, Vol. 48, p. 35607, August 5, 1983; p. 38449 , August 24, 1983. J.S. NRC, Washington, D.r.

U.S. Nuclear Regulatory Commission. 1984e. Code of Federal Regulations, Title 10, Energy, Part 60, Disposal of High-Level Radioactive Wastes in Geologic Repositories (Subpart E: Technical Criteria). Final Rule. U.S. Federal Register, Vol. 48, No. 120, June 21, 1983, pp. 28194-28229. U.S. NRC, Washington, D.C.

U.S. Nuclear Regulatory Commission. 1984f. Code of Federal Regulations, Title 10, Energy; Part 61, Licensing Requirements for Land Disposal of Radioactive Waste, Final Rule. IJ.S. Federal Register, Vol. 47, December 27, 1982 (Effective January 26, 1983), P. 57463. U.S. NRC, Washington, D.C.

Westinghouse Electric Company. 1984. TRU Waste Acceptance Criteria for the Waste Isolation Pilot Plant. WIPP-DOE-069, Rev. 2, Draft C, Albuquerque, New Mexico. 
APPENOIX D

PROCESSING, TRANSPORTATION, AND DISPOSAL

COST ESTIMATES 
APPENDIX D

PROCESSING, TRANSPORTATION, AND DISPOSAL

COST ESTIMATES

\section{D.1. PROCESSING COST ESTIMATE}

The capital and operating cost estimates for each treatment option studied in this report were taken from Mckee et a1. (1984) when available. For those operating costs not available in the Mckee study, the capital and operating costs were approximated by the authors. Table D.1 gives the capital cost estimates and Table 0.2 gives the operating cost estimates for each TRUW treatment option. Al1 cost estimates are based on undiscounted 1983 dollars.

Included in the operating cost are the cost of replacing the used containers and the cost of purchasing containers to package the processed waste. Table 0.3 describes the containers used in this study and gives the costs of these containers.

\section{D.2 TRANSPORTATION COST ESTIMATE}

This section describes the cost estimates for transporting the wastes in two subsections; the first considers TRUW and HLW transported to a repository, and the second considers LLW transportation costs.

\section{D.2.1 TRUW and HLW Transport Cost Estimation}

The TRUW and HLW transport cost estimate for this report is based on a transportation cost analysis in the Mckee study. The transportation costs for TRUW consisted of a cask leasing fee and freight charges. For this study it was simplest to calculate the transportation costs on a per shipment basis. Table 0.4 gives the parameters needed to determine the number of drums a shipment can carry. For example, for RH 55-gal drums with a surface dose of less than $1 \mathrm{R} / \mathrm{hr}$, a shipment consists of three casks. Each cask contains 14 drums. Therefore each shipment transports (3 casks) (14 drums/cask), or 42 55-gal drums. 
TABLE D.1. Capital Costs for the Six TFUW Treatment Options

\begin{tabular}{|c|c|c|}
\hline Option & Facility & $\begin{array}{c}\text { Capital Cost } \\
\text { for } \\
1,500 \mathrm{MTU} / \mathrm{yr} \\
\text { Reprocessing, } \$ M \\
\end{array}$ \\
\hline 1 & $\begin{array}{l}\text { HLW vitrification } \\
\text { TRUW storage } \\
\text { Waste assay }\end{array}$ & $\begin{array}{l}170(a) \\
32(b) \\
34(a)\end{array}$ \\
\hline 2 & $\begin{array}{l}\text { HLW vitrification } \\
\text { TRUW storage } \\
\text { Waste assay } \\
\text { TRUW treatment }\end{array}$ & $\begin{array}{l}179(\mathrm{a}) \\
24(\mathrm{~b}) \\
34(\mathrm{a}) \\
40^{(\mathrm{c})}\end{array}$ \\
\hline 3 & $\begin{array}{l}\text { HLW vitrification } \\
\text { TRUW storage } \\
\text { Waste assay } \\
\text { TRUW treatment }\end{array}$ & $\begin{array}{l}170(a) \\
33(b) \\
34(a) \\
40\end{array}$ \\
\hline 4 & $\begin{array}{l}\text { HLW vitrification } \\
\text { TRUW storage } \\
\text { Waste assay } \\
\text { TRUW treatment }\end{array}$ & $\begin{array}{l}179^{(a)} \\
21(b) \\
34(a) \\
93(c)\end{array}$ \\
\hline $5 A$ & $\begin{array}{l}\text { HLW vitrification } \\
\text { TRUW storage } \\
\text { Waste assay } \\
\text { TRUW treatment }\end{array}$ & $\begin{array}{l}200(a, c) \\
21(b) \\
34(a) \\
115^{(c)}\end{array}$ \\
\hline $5 B$ & $\begin{array}{l}\text { HLW vitrification } \\
\text { TRUW storage } \\
\text { Waste assay } \\
\text { TRUW treatment }\end{array}$ & $\begin{array}{l}170^{(a)} \\
21(b) \\
34(a) \\
145^{(c)}\end{array}$ \\
\hline 6 & $\begin{array}{l}\text { HLW vitrification } \\
\text { TRUW storage } \\
\text { Waste assay } \\
\text { TRUW treatment }\end{array}$ & $\begin{array}{l}170(a) \\
21(b) \\
34(a) \\
95(c)\end{array}$ \\
\hline
\end{tabular}

(a) Cost estimates are from Mckee et al. (1984).

(b) Cost estimates are based on those in Mckee et al. (1984), which were then scaled to appropriate capacities using the following exponential scaling factors: 0.5 for processing facilities, 0.6 for RH storage, and 0.8 for $\mathrm{CH}$ storage.

(c) Estimated by the authors. 
TABLE D.2. Operating Costs Based on 1,500 MTU/yr for the Six TRUW Treatment Options(a)

\begin{tabular}{|c|c|c|c|c|}
\hline Option & Facility & $\begin{array}{l}\text { Operating } \\
\text { Cost, } 8 \mathrm{M} / \mathrm{yr} \\
\end{array}$ & $\begin{array}{l}\text { Canister } \\
\text { Cost, } \$ M / y r \\
\end{array}$ & $\begin{array}{c}\text { Total } \\
\text { Operating } \\
\text { Cost, } \$ M / y r \\
\end{array}$ \\
\hline 1 & $\begin{array}{l}\text { HLW vitrification(b) } \\
\text { TRUW storage (b) } \\
\text { Waste assay }(b) \\
\text { Total }\end{array}$ & $\begin{array}{l}5.8 \\
1.9 \\
2.0\end{array}$ & $\begin{array}{l}5.3 \\
5.9 \\
--\end{array}$ & $\begin{array}{r}11.1 \\
7.8 \\
2.0 \\
20.9\end{array}$ \\
\hline 2 & $\begin{array}{l}\text { HLW vitrification(b) } \\
\text { TRUW storage(b) } \\
\text { Waste assay }(b) \\
\text { TRUw treatment }(c) \\
\text { Total }\end{array}$ & $\begin{array}{l}5.8 \\
1.4 \\
2.0 \\
2.4\end{array}$ & $\begin{array}{l}5.3 \\
1.1 \\
-- \\
--\end{array}$ & $\begin{array}{r}11.1 \\
2.5 \\
2.0 \\
2.4 \\
18.0\end{array}$ \\
\hline 3 & $\begin{array}{l}\text { HLW vitrification(b) } \\
\text { TRUW storage (b) } \\
\text { Waste assay }(b) \\
\text { TRUW treatment }(c) \\
\text { Total }\end{array}$ & $\begin{array}{l}5.8 \\
2.0 \\
2.0 \\
0.8\end{array}$ & $\begin{array}{l}5.3 \\
1.3 \\
-- \\
--\end{array}$ & $\begin{array}{r}11.1 \\
3.3 \\
2.0 \\
0.8 \\
17.2\end{array}$ \\
\hline 4 & $\begin{array}{l}\text { HLW vitrificatjon }(b) \\
\text { TRUw storage }(b) \\
\text { Waste assay }(b) \\
\text { TRUw treatment }(c) \\
\text { Total }\end{array}$ & $\begin{array}{l}5.8 \\
1.3 \\
2.0 \\
6.4\end{array}$ & $\begin{array}{l}5.3 \\
0.4 \\
-- \\
--\end{array}$ & $\begin{array}{r}11.1 \\
1.7 \\
2.0 \\
6.4 \\
21.2\end{array}$ \\
\hline $5 \mathrm{~A}$ & $\begin{array}{l}\text { HLW vitrification(b) } \\
\text { TRUw storage (b) } \\
\text { Waste assay }(b) \\
\text { TRUw treatment }(c) \\
\text { Total }\end{array}$ & $\begin{array}{l}6.8 \\
1.3 \\
2.0 \\
7.3\end{array}$ & $\begin{array}{l}6.6 \\
2.1 \\
-- \\
--\end{array}$ & $\begin{array}{r}13.4 \\
3.3 \\
2.0 \\
7.3 \\
26.0\end{array}$ \\
\hline $5 B$ & $\begin{array}{l}\text { HLW vitrification(b) } \\
\text { TRUW storage(b) } \\
\text { Waste assay (b) } \\
\text { TRUW treatment (c) } \\
\text { Total }\end{array}$ & $\begin{array}{l}5.8 \\
1.3 \\
2.0 \\
9.1\end{array}$ & $\begin{array}{l}5.3 \\
2.2 \\
-- \\
-.\end{array}$ & $\begin{array}{r}11.1 \\
3.5 \\
2.0 \\
9.1 \\
25.7\end{array}$ \\
\hline 6 & $\begin{array}{l}\text { HLW vitrification(b) } \\
\text { TRUW storage (b) } \\
\text { Waste assay (b) } \\
\text { TRUw treatment (c) } \\
\text { Total }\end{array}$ & $\begin{array}{l}5.8 \\
1.3 \\
2.0 \\
5.7\end{array}$ & $\begin{array}{l}5.3 \\
0.5 \\
-- \\
--\end{array}$ & $\begin{array}{r}11.1 \\
1.8 \\
2.0 \\
5.7 \\
20.6\end{array}$ \\
\hline
\end{tabular}

(a) Costs are for one reprocessing plant operating at a rate of 1,501 MTU/yr.

(b) Cost estimates are from Mckee et al. (1984). Costs are scaled to appropriate capacities using the following exponential scaling factors based on capacity: 0.6 for RH storage and 0.8 for $\mathrm{CH}$ storage.

(c) Fraction of capital cost representing operating cost (minus canister and drum costs) estimated by authors based on analys is of operating costs in DOE/ET-0028 (U.S. DOE 1979). 
TABLE D.3. Container Description and Cost

\begin{tabular}{|c|c|c|}
\hline Container/Drum Size & Material Type & Cost (mid-1983 \$/container) \\
\hline 55-gal drum & Galvanized mild steel & $6 D^{(a)}$ \\
\hline 55-gal drum & Stainless steel & $300^{(b)}$ \\
\hline 80-gal drum & Galvanized mild steel & $120(c)$ \\
\hline 53-gal canister & Stainless steel & $8,100(d, e)$ \\
\hline 160-gat canister & Stainless steel & $8,100(d)$ \\
\hline 160 -gal canister & Mild steel & $2,000^{(b, f)}$ \\
\hline 160-gal canister & Mild steel & $4,000(g)$ \\
\hline 600 -gal canister & Stainless steel & $14,500(d, h)$ \\
\hline 600-gal canister & Mild steel & $3,600(c)$ \\
\hline
\end{tabular}

(a) Rockwell-Hanford Operations costs for WIPP qualified containers.

(b) Estimated from cost of other container in this size using cost of fabricated stainless steel equal to 4 times the cost of fabricated mild steel.

(c) Estimated by authors, based on costs for 55-gal drum.

(d) From Mckee et al. (1984).

(e) A canister is used for HLW (MCKee et a $\mathrm{a}^{i}$ 1984).

(f) This cost per canister is also used for LLW Class C. Cost is based on scaledown from larger, commercially available canisters.

(g) Cost is for hot pressing canisters, to include cost of compressible inner canisters.

(h) A canister is used for Option 1 because of process needs.

The cask leasing charges are from the Mckee et al. (1984) study and the freight charges are from a study by McNair et al. (1984). These transport charges are given in Table D.5.

As an example of how the transport costs were calculated, assume that some RH 55-gal drums with a surface dose $<1 \mathrm{R} / \mathrm{hr}$ are to be transported. A shipment of these drums consists of 42 drums. The cask leasing fee for 55-gal drums is $\$ 200 /$ day/cask. The round-trip transit time is 24 days. Since each shipment contains 3 casks, the cask leasing fee per shipment $=(\$ 200 /$ day $/$ cask $)(24$ days $)$ (3 casks/shipment), or $\$ 14,400 /$ shipment of 42 RH 55 -gal drums with a surface dose less than $1 \mathrm{R} / \mathrm{hr}$. It is assumed that each shipment is accompanied by an escort for $\$ 1,900$ per shipment. The cost per shioment of transporting a filled 


\section{TABLE D.4. Transportation Parameters for TRUW and HLW}

\begin{tabular}{|c|c|c|c|c|c|}
\hline \multirow[b]{2}{*}{ Waste and Container Type } & \multirow{2}{*}{$\begin{array}{l}\text { Number of } \\
\text { Containers/ } \\
\text { Transport } \\
\text { Packaging } \\
\end{array}$} & \multirow[t]{2}{*}{$\begin{array}{c}\text { Number of } \\
\text { Transport } \\
\text { Packaqing/ } \\
\text { Rail } \\
\text { Shipment } \\
\end{array}$} & \multirow{2}{*}{$\begin{array}{c}\text { Type of Rail } \\
\text { Cask }\end{array}$} & \multicolumn{2}{|c|}{$\begin{array}{l}\text { Transport Packaging } \\
\text { We ight, ka/cask } \\
\text { Packaging }\end{array}$} \\
\hline & & & & EmpTy & Loader \\
\hline \multicolumn{6}{|l|}{ RH TRUN } \\
\hline 55-gal drum, <1 $\mathrm{R}^{(b)}$ & 14 & 3 & CNS14-170 $(\mathrm{C})$ & 72,600 & 90,700 \\
\hline $55-\mathrm{gal} d r u m,>1 R^{(b)}$ & 7 & 3 & CNS7-100 & 72,600 & 90,700 \\
\hline 80-gal drum, <1 $\mathrm{R}^{(\mathrm{b})}$ & 10 & 3 & CNS14-170 ${ }^{(\mathrm{C})}$ & 72,600 & 90,700 \\
\hline 80-gal drum, >1 $\mathrm{R}^{(\mathrm{b})}$ & 5 & 3 & CNS7-100 $(\mathrm{C})$ & 72,600 & 90,700 \\
\hline 160-gal canister & $7^{(d)}$ & 1 & DHLH-rati ${ }^{(e)}$ & 80,500 & 90,700 \\
\hline 600-gal canister & 1 & 1 & $\begin{array}{l}\text { Cladding } \\
\text { hulls-rail (c) }\end{array}$ & 70,800 & $78,000^{(f)}$ \\
\hline \multicolumn{6}{|l|}{ CH TRUW } \\
\hline 55-gal drum & 54 & 2 & TRUPACT $^{(b)}$ & 36,300 & 63,500 \\
\hline 80 -gal drum & 42 & 2 & TRUPACT $^{(b)}$ & 36,300 & 63,500 \\
\hline 160-gal canister & 18 & 2 & TRUPACT ${ }^{(b)}$ & 36,300 & 63,500 \\
\hline $600-g a 1$ canister & 1 & 1 & $\begin{array}{l}\text { Cladding } \\
\text { nul|s-rail (b) }\end{array}$ & 70,800 & $78,000^{(f)}$ \\
\hline \multicolumn{6}{|l|}{$H L H$} \\
\hline 200-L CHLW canister & 12 & 1 & CHLW-raili ${ }^{(b)}$ & 70,000 & 80,300 \\
\hline 320-L CHLW canister & 7 & 1 & CHLW-raij ${ }^{(b)}$ & 70,000 & 80,300 \\
\hline
\end{tabular}

(a) Source of these packaging weights is wilmot ot al. (1983), unless specified otherwise.

(b) <l $R$ means surface dose rate $<1 \mathrm{R} / \mathrm{hr}$ and $>1 \mathrm{R}$ means surface dose rate $>1 \mathrm{R} / \mathrm{hr}$.

(c) Capacity of rail cask is given by wilmot et al. (1983). Cavity is 56 inches in diameter.

(d) It is assumed that a DHLW cask can hold seven 160-gal canisters.

(e) Capacity of rail cask is given by wilmot et al. (1983). Cavity is 88 inches in diameter.

(f) The maximum weight of a $600 \mathrm{ngal}$ canister from any of the TRUw treatment processes is $6,700 \mathrm{~kg}$. This is added to the empty weight of the $600 \mathrm{aal}$ transport packaging weight $(70,800 \mathrm{~kg})$ to obtain the loaded weight of $78,000 \mathrm{~kg}$.

cask containing 55-gal drums of waste and then returning the empty cask is $\$ 30,56 \mathrm{n} / \mathrm{sh}$ ipment. Therefore the total cost of transporting the waste is the freight cost of $\$ 32,460(\$ 1,900+\$ 30,560)$ plus the cask leasing fee of $\$ 14,400$, for a total of $\$ 46,860$.

Tables 0.6 through 0.9 give the cost of transporting the waste generated from each treatment option. The costs are given by waste type on a basis of 


\section{TABLE D.5. Cask Leasing and Freight Charges for Transporting TRtJW and HLW}

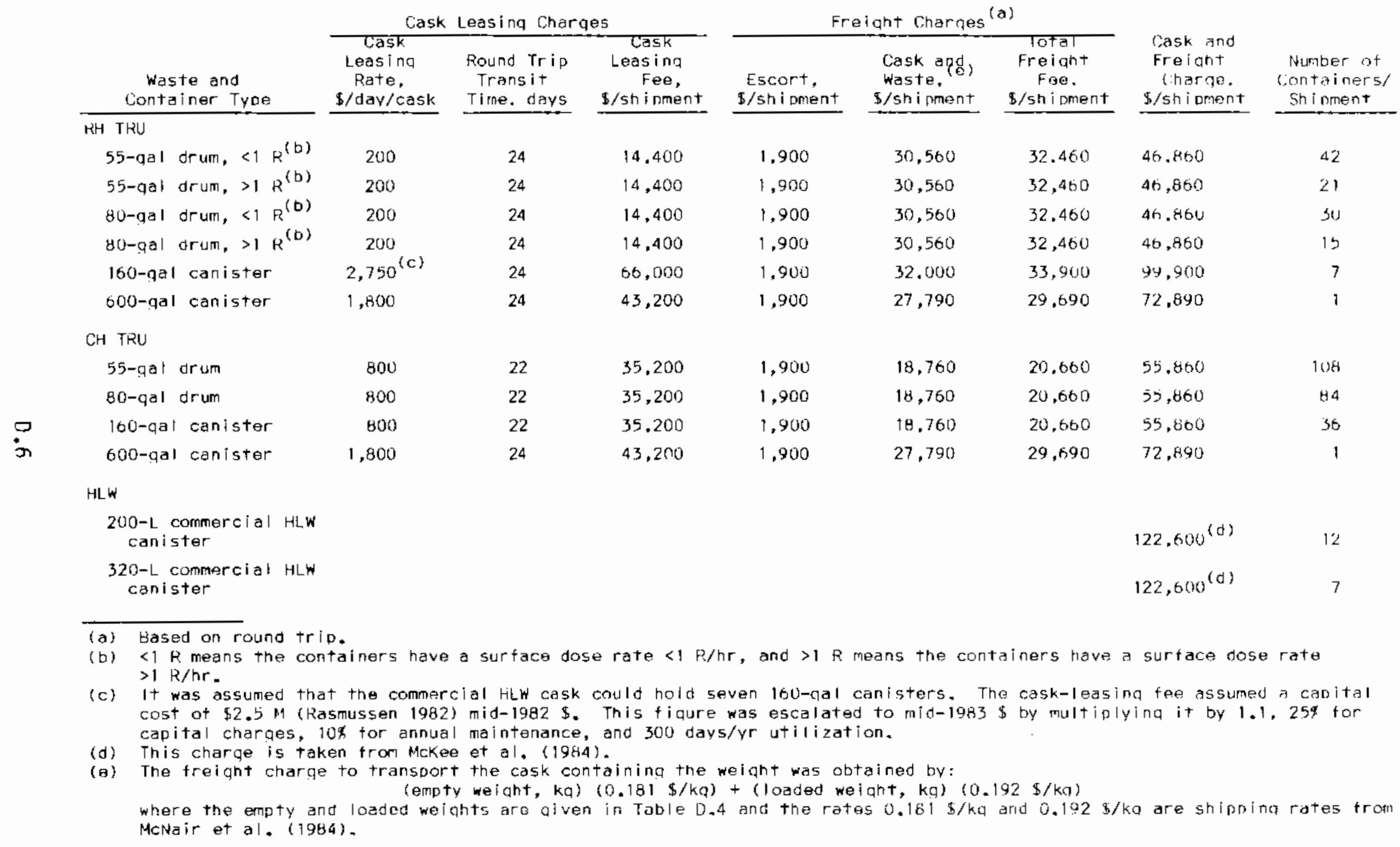



TABLE D.6. Transport Quantities and Costs for 1,500 MTU
Reprocessed Waste/yr for Options 1 and 2 (a)

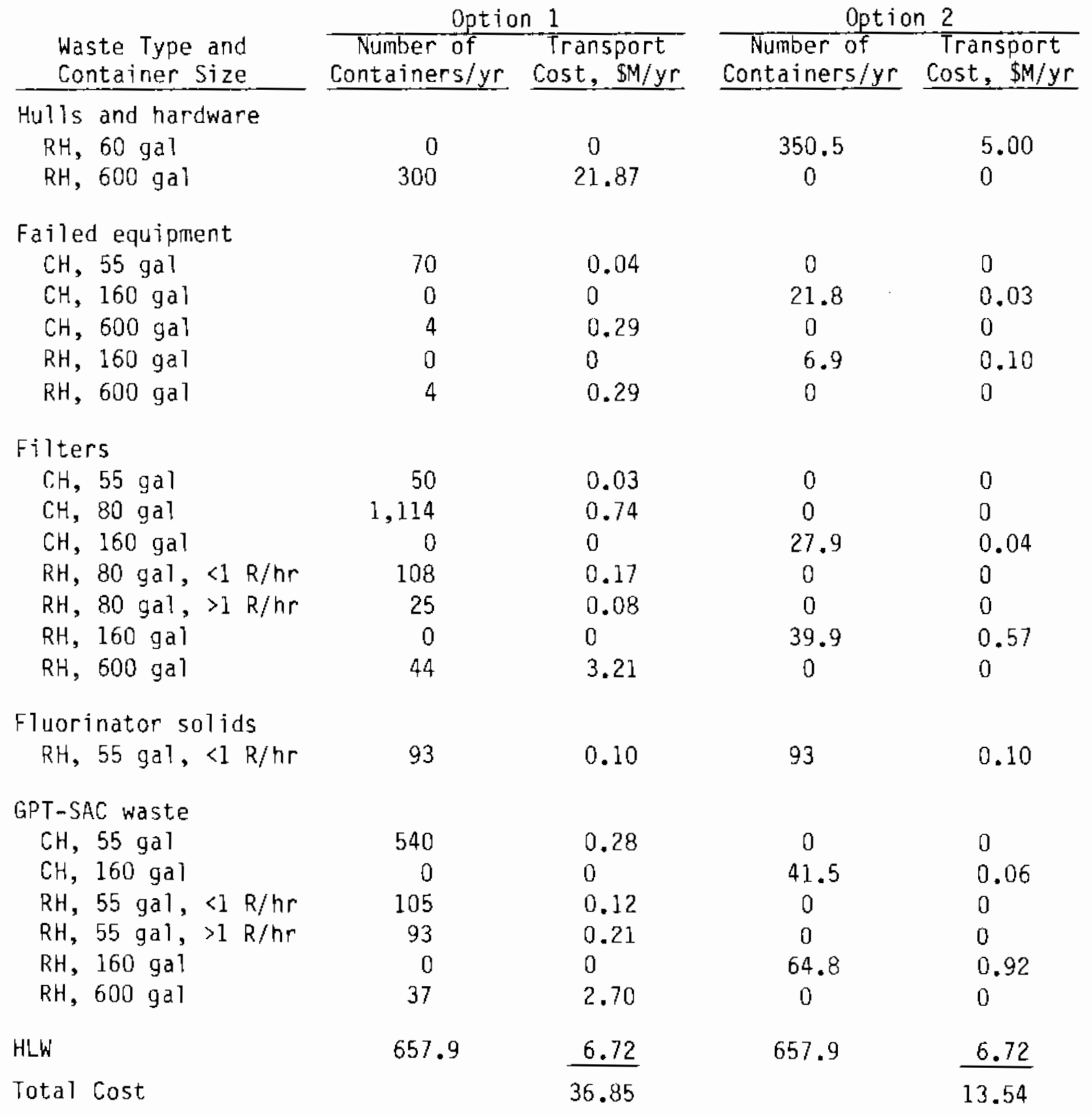

(a) Values are shown in more significant figures than the accuracy of the data to maintain consistency of the calculations. 
TABLE D.7. Transport Quantities and Costs for 1,500 MTU
Reprocessed Waste/yr for lotions 3 and $4(a)$

\begin{tabular}{|c|c|c|c|c|}
\hline \multirow{2}{*}{$\begin{array}{l}\text { Waste Type and } \\
\text { Container Size }\end{array}$} & \multicolumn{2}{|c|}{ Option 3} & \multicolumn{2}{|c|}{ Option 4} \\
\hline & $\begin{array}{c}\text { Number of } \\
\text { Containers/yr }\end{array}$ & $\begin{array}{l}\text { Transport } \\
\text { Cost, } \$ M / y r \\
\end{array}$ & $\begin{array}{c}\text { Number of } \\
\text { Containers/yr }\end{array}$ & $\begin{array}{l}\text { Transport } \\
\text { Cost, } \$ M / y r\end{array}$ \\
\hline \multicolumn{5}{|l|}{ Hulls and hardware } \\
\hline $\mathrm{RH}, 160 \mathrm{gal}$ & 0 & 0 & 152.3 & 2.17 \\
\hline $\mathrm{RH}, 600 \mathrm{gal}$ & 343 & 25.00 & 0 & 0 \\
\hline \multicolumn{5}{|l|}{ Failed equipment } \\
\hline $\mathrm{CH}, 55 \mathrm{gal}$ & 70 & 0.04 & 0 & 0 \\
\hline $\mathrm{CH}, 160 \mathrm{gal}$ & 0 & 0 & 4.6 & 0.01 \\
\hline $\mathrm{CH}, 600 \mathrm{gal}$ & 5 & 0.36 & 0 & 0 \\
\hline $\mathrm{RH}, 160 \mathrm{gal}$ & 0 & 0 & 0.9 & 0.01 \\
\hline $\mathrm{RH}, 600 \mathrm{gal}$ & 3 & 0.22 & 0 & 0 \\
\hline \multicolumn{5}{|l|}{ Filters } \\
\hline $\mathrm{CH}, 55 \mathrm{gal}$ & 131.4 & 0.07 & 0 & 0 \\
\hline $\mathrm{CH}, 160 \mathrm{gal}$ & 0 & 0 & 3.9 & 0.01 \\
\hline $\mathrm{RH}, 55 \mathrm{gal},<1 \mathrm{R} / \mathrm{hr}$ & 75.5 & 0.08 & 0 & 0 \\
\hline $\mathrm{RH}, 55 \mathrm{gal},>1 \mathrm{R} / \mathrm{hr}$ & 53.1 & 0.12 & 0 & 0 \\
\hline $\mathrm{RH}, 160 \mathrm{gal}$ & 0 & 0 & 3.7 & 0.05 \\
\hline \multicolumn{5}{|l|}{ Fluorinator solids } \\
\hline $\mathrm{RH}, 160 \mathrm{gal}$ & 0 & 0 & 15.5 & 0.22 \\
\hline \multicolumn{5}{|l|}{ GPT-SAC waste } \\
\hline $\mathrm{CH}, 55 \mathrm{gal}$ & 170.5 & 0.09 & 0 & 0 \\
\hline $\mathrm{CH}, 160 \mathrm{gal}$ & 0 & 0 & 3.7 & 0.01 \\
\hline $\mathrm{RH}, 55 \mathrm{gal},<1 \mathrm{R} / \mathrm{hr}$ & 118.9 & 0.13 & 0 & 0 \\
\hline $\mathrm{RH}, 55 \mathrm{gal},>1 \mathrm{R} / \mathrm{hr}$ & 88.6 & 0.20 & 0 & 0 \\
\hline $\mathrm{RH}, 160 \mathrm{gal}$ & 0 & 0 & 5.6 & 0.08 \\
\hline$H L W$ & 657.9 & 6.72 & 657.9 & 6.72 \\
\hline Total cost & & 33.03 & & 9.28 \\
\hline
\end{tabular}

(a) Values are shown in more significant figures than the accuracy of the data to maintain consistency of the calculations. 
TABLE D.8. Transport Quantities and Costs for 1,500 MTU
Reprocessed Waste/yr for Option $5(a)$

\begin{tabular}{|c|c|c|c|c|}
\hline \multirow[b]{2}{*}{$\begin{array}{l}\text { Waste Type and } \\
\text { Container Size }\end{array}$} & \multicolumn{2}{|c|}{ Suboption 5A } & \multicolumn{2}{|c|}{ Suboption 5B } \\
\hline & $\begin{array}{c}\text { Number of } \\
\text { Containers/yr }\end{array}$ & $\begin{array}{l}\text { Transport } \\
\text { Cost, } \mathbb{M M} / y r\end{array}$ & $\begin{array}{l}\text { Number of } \\
\text { Containers/yr }\end{array}$ & $\begin{array}{l}\text { Transport } \\
\text { Cost, } \$ M / y r\end{array}$ \\
\hline \multicolumn{5}{|l|}{ Hulls and hardware } \\
\hline LLW, 160 gal & 657.9 & 0.93 & 657.9 & 0.93 \\
\hline HLW contribution $(a)$ & $79.3^{(b)}$ & 4.58 & $0.3^{(b)}$ & $\sim 0$ \\
\hline RH, 160 gal & 0 & 0 & 15.2 & 0.22 \\
\hline \multicolumn{5}{|l|}{ Failed equipment } \\
\hline LLW, 160 gal & 16.7 & 0.0006 & 16.7 & 0.0006 \\
\hline HLW contribution $(a)$ & $0.05(b)$ & 0.003 & $0.05^{(b)}$ & 0 \\
\hline $\mathrm{CH}, 160 \mathrm{ga}]$ & 6.5 & 0.01 & 6.5 & 0.01 \\
\hline RH, 160 gal & 2.1 & 0.03 & 2.1 & 0.03 \\
\hline \multicolumn{5}{|l|}{ Filters } \\
\hline $\mathrm{LLW}, 160 \mathrm{gal}$ & 35.8 & 0.001 & 35.8 & 0.001 \\
\hline HLW contribution $(a)$ & $3.5^{(b)}$ & 0.20 & $3.5^{(b)}$ & $\sim$ \\
\hline \multicolumn{5}{|l|}{ Fluorinator solids } \\
\hline LLW, 160 gal & 34.0 & 0.01 & 34.0 & 0.01 \\
\hline \multicolumn{5}{|l|}{ GPT-SAC waste } \\
\hline LLW, 160 gal & 130.2 & 0.005 & 130.2 & 0.005 \\
\hline HLW contribution $(a)$ & $0.3^{(b)}$ & 0.02 & 0.3 & $\sim$ \\
\hline $\mathrm{CH}, 160$ gal & 0.7 & 0.001 & 0.7 & 0.001 \\
\hline $\mathrm{RH}, 55 \mathrm{gal},>1 \mathrm{R} / \mathrm{hr}$ & 57.4 & 0.13 & 57.4 & 0.13 \\
\hline $\mathrm{RH}, 160$ ga 1 & 1.1 & 0.02 & 1.1 & 0.02 \\
\hline HLW & $131.6^{(b)}$ & 6.72 & $131.6^{(b)}$ & 6.72 \\
\hline Total cost & & 12.6 & & 8.0 \\
\hline
\end{tabular}

\footnotetext{
(a) Values are shown in more significant figures than the accuracy of the data to maintain chnsistency of the calculations.

(b) Value is in $\mathrm{m}^{3} / \mathrm{yr}$.
} 
TABLE D.9. Transport Quantities and Costs for 1,500 MTU
Reprocessed Waste/yr for Option $6(a)$

\begin{tabular}{|c|c|c|}
\hline \multirow[b]{2}{*}{$\begin{array}{l}\text { Waste Type and } \\
\text { Container Size }\end{array}$} & \multicolumn{2}{|c|}{ Option 6} \\
\hline & $\begin{array}{l}\text { Number of } \\
\text { Containers/yr }\end{array}$ & $\begin{array}{l}\text { Transport } \\
\text { Cost, } \$ M / y r\end{array}$ \\
\hline Hulls and har & & \\
\hline RH, 160 gal & 152.3 & 2.17 \\
\hline
\end{tabular}

Failed equipment

$\begin{array}{lll}\mathrm{CH}, 160 \mathrm{gal} & 4.6 & 0.01 \\ \mathrm{RH}, 160 \mathrm{gal} & 1.0 & 0.01\end{array}$

Filters

$\begin{array}{lrl}\mathrm{CH}, 55 \mathrm{gal} & 113.5 & 0.06 \\ \mathrm{RH}, 55 \mathrm{gal}<1 \mathrm{R} / \mathrm{hr} & 36.8 & 0.04 \\ \mathrm{RH}, 55 \mathrm{gal}>1 \mathrm{R} / \mathrm{hr} & 36.4 & 0.08\end{array}$

Fluorinator solids
LLW, $160 \mathrm{gal}$
94.6
0.04

GPT, SAC waste

$\mathrm{CH}, 55$ gal

$6.2 \quad 0.003$

$\mathrm{CH}, 160 \mathrm{gal}$

0.3

0.0005

$\mathrm{RH}, 55$ gal $>1 \mathrm{R} / \mathrm{hr}$

11.7

0.03

$\mathrm{RH}, 160 \mathrm{gal}$

$0.8 \quad 0.01$

HLW

657.9

$\frac{6.72}{9.17}$

Total Cost
(a) Values are shown in more significant figures than the accuracy of the data to maintain consistency of the calculations.

1,500 MTU/yr reprocessed. With Suboptions 5A and 5B (Table D.8) additional HLW is generated during TRUW treatment. These $H_{L} W$ quantities are shown separately from the $H L W$ produced from the liquid waste solidification as the $H L W$ contribution by waste type. Transport costs for LLW, included in Tables 0.6 through 
0.9 for Options 5 and 6, are discussed in Section 0.2.2. Table 8.4 summarizes Tables 0.5 through 0.9 and gives the total transport costs based on 1,500 MTI) and $70,000 \mathrm{MTU}$ reprocessed.

\section{D.2.2 LLW Transport Cost Estimation}

The LLW produced in Suboptions 5A, 5B and 0ption 6 is transported by truck to a disposal facility 300 miles away in the eastern U.S. The low-level fuel hardware is highly radioactive and is therefore transported in a commercial cladding hulls cask. The shipment has a round trip transit time of 1.5 days (for a truck traveling $35 \mathrm{mi} / \mathrm{hr}, 12 \mathrm{hr} /$ day, $600 \mathrm{miles}$ round trip). The cask leasing fee for a commercial hulls cask is $\$ 1,275 /$ day (adjusted $16 \%$ from 1981 dollars to 1983 dollars) (Wilmot et al. 1983). The freight charges are $\$ 2,660 /$ shipment (McNair et a1. 1984). Therefore the total transport cost for the decontaminated hardware is $\$ 4,570 /$ shipment $\Gamma(\$ 1,275 /$ day $\times 1.5$ days $)+$ $\$ ?, 660) 7$. Fach shipment contains only one 160 -gal container of spent fuel hardware as LLW.

The cost of transporting the other LLW (hulls, failed equipment, filters, fluorinator solids, and GPT-SAC waste) is based on an analys is in DOE/LLW-6Td (EGRG Idaho 1983). Due to its low surface dose rate (see Section 0.3.?), it was assumed that the low-level failed equipment, filters, and GPT-SAC waste do not require shielding or a cask. It has a transport cost of $\$ 864 /$ shipment (adjusted 16\% from 1981 dollars to 1983 dollars). The volume of a shipment of waste not requiring shielding is $14.2 \mathrm{~m}^{3}\left(500 \mathrm{ft}^{3}\right)$. The hulls and fluorinator solids are classified as shielded waste. The cost of transporting shielded waste is $\$ 512 / \mathrm{m}^{3}$, plus $\$ 870 /$ shipment for leasing the cask. Each shielded waste shipment contains $4.25 \mathrm{~m}^{3}\left(150 \mathrm{ft}^{3}\right)$ of waste. Therefore the cost of transporting shielded waste is $\$ 3,040 /$ shipment.

Table 0.10 gives the packaged volume of LLW from nptions 5 and 5 and the cost of transporting it to a LLW disposal facility. These quantities are also included in Tables 0.6 through 0.9 . 
TABLE 0.10. Quantities and Transport Costs for LLW(a)

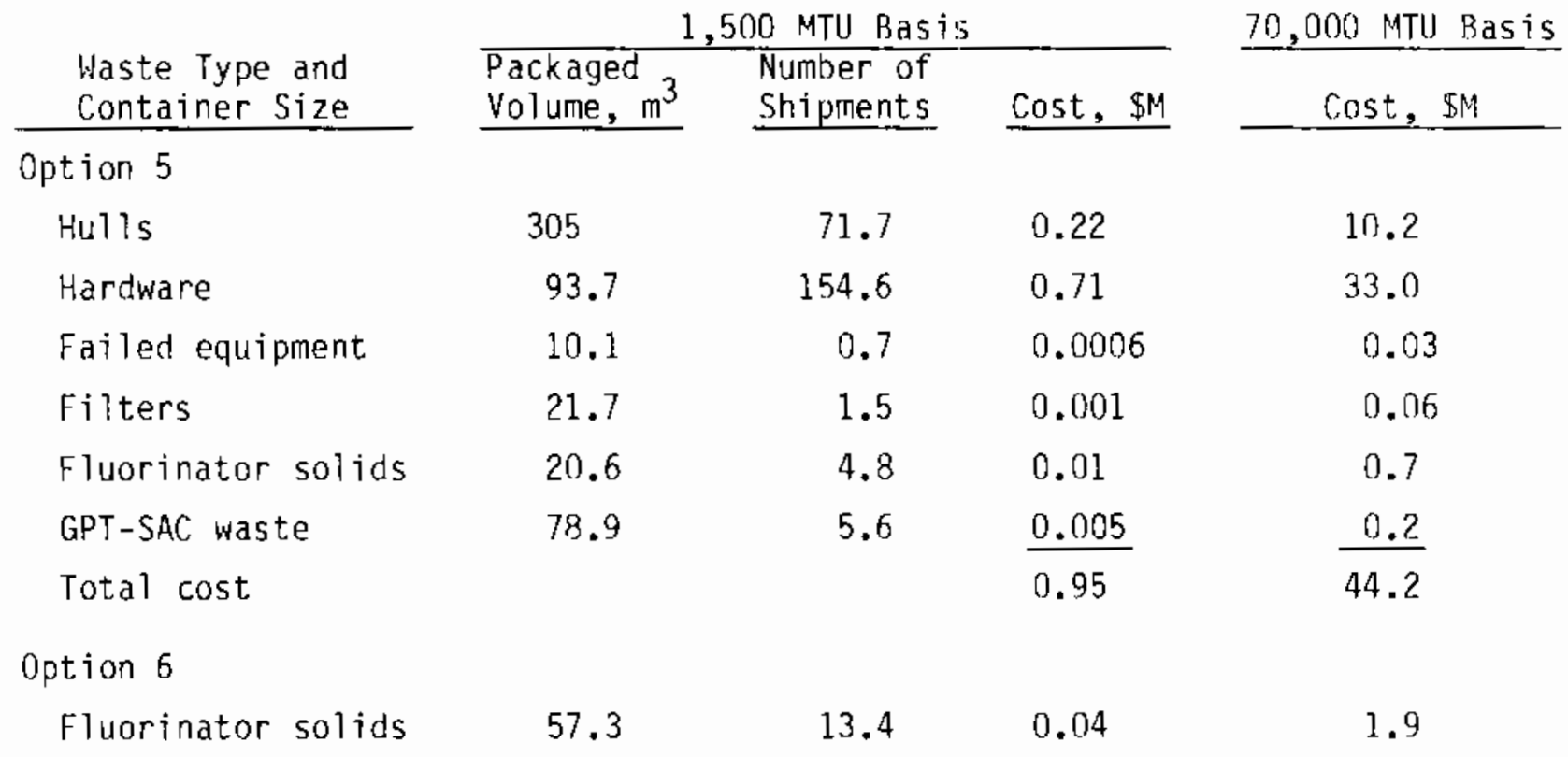

(a) Values are shown in more significant figures than the accuracy of the data to maintain consistency of the calculations.

\section{D.3 DISPOSAL COST ESTIMATIONS}

The disposal costs assume that the TRUW and HLW are disposed at a repository in basalt and that the LLW is disposed of at a low-level radioactive waste disposal facility.

\section{D.3.1 TRUW and HLW Disposal Cost Estimator}

The disposal costs for TRUW and HLW were estimated using a repository cost computer code RECON ( $\mathrm{Clark}$ 1983), which gives the life-cycle construction and operating costs of a geologic repository. It was assumed that the repository has the capacity for 70,000 MTII of reprocessed waste, that it could accept both TRUW and HLW, that the RH TRUW and HLW are placed remotely into horizontal boreholes, and that the C.H TRUW containers are stacked in the corridors with overpack canisters. The computer model includes labor requirements, rates, waste receiving, packing transport, emplacement, rock excavation, backfilling, sealing, and decommissioning. The repository used in RECON is based on the 1983 reference design concept for the B.WIP (Kaiser Engineers Inc./Parsons, Brinkerhoff, Quade, and Douglas, Inc. 1983). 
Table D.11 gives the cost of disposing the TRUW and HLW listed in Table 7.9. This information is given in Table 8.5 by waste type. Table 8.5 was obtained by dividing the values in Table 0.11 by the quantities of containers and drums in Table 7.9, which have been scaled for 70,000 MTU reprocessed.

\section{D.3.2 LLW Disposal Cost Estimation}

The LLW disposal facility at Barnwell, South Carolina is the representative LLW disposal facility for this study. The cost schedule (effective January 1,1984 ) for disposing LLW at this facility is given in Appendix $E$.

For Option 5, Table 0.12 lists, for each waste type, the parameters needed to obtain unit costs from the LLW disposal cost schedule in Appendix $E$. (Because the cost schedule in Appendix $E$ is in English units, the discussion in this subsection is as well.)

The number of 160-gal canisters/yr is taken from Tables 7.6 or 7.7 . The 1b/canister is obtained by taking the weight per waste type per year from Tables 7.6 or 7.7 , dividing it by the number of canisters/yr and adding to this

TABLE D.11. Disposal Costs for TRUW and HLW Based on 70,000 MTU

\begin{tabular}{|c|c|c|c|c|c|c|c|c|}
\hline & & & & tal Cost. & & & & \\
\hline $\begin{array}{c}\text { Containter } \\
\text { Size }\end{array}$ & Option 1 & Ootion 2 & Ootion 3 & Option 4 & $\begin{array}{l}\text { Subon- } \\
\text { tion } 58 \\
\end{array}$ & $\begin{array}{l}\text { Suhoo- } \\
+1 \text { on } 5 b \\
\end{array}$ & notion & 6 \\
\hline $\mathrm{CH}, 55 \mathrm{aal}$ & 99 & 0 & 108 & 0 & 0 & 0 & 71 & \\
\hline $\mathrm{CH}, \mathrm{BO} \mathrm{ab}$ & 205 & 0 & 0 & 0 & 0 & 0 & 0 & \\
\hline $\mathrm{CH}, 160 \mathrm{al}$ & 0 & 119 & 0 & 56 & 63 & 63 & 5 & \\
\hline $\mathrm{CH}, \mathrm{SOO}$ oal & 5 & 0 & 0 & 0 & 0 & 0 & n & \\
\hline $\mathrm{RH}, 55$ al! & 32.5 & 109 & 392 & 0 & 82 & 82 & 108 & \\
\hline $\mathrm{RH}$, \&ก na। & 147 & 0 & 0 & 0 & 0 & 0 & 0 & \\
\hline RH, 160 तล 1 & n & $122 \kappa$ & 0 & 535 & 43 & 43 & 445 & \\
\hline RH, 500 וaה & 1448 & $n$ & $134 \mathrm{~A}$ & 0 & 0 & 0 & ก & \\
\hline$H L w, 3 \cap n L$ & 2630 & 2785 & 2775 & 3013 & 37.05 & 3154 & 2970 & \\
\hline Total & 4867 & 47.40 & 4622 & $36 \cap 3$ & 3394 & 3352 & 3601 & \\
\hline
\end{tabular}

(a) Values are shown in more sinniflcant fiaures than the accurack of the rata to maintain consistency of the calculations. 
TABLE 0.12. Parameters for nisposal for LLW from nption 5 Based on 1,500 MTU Reprocessed wasta/yr (a)

\begin{tabular}{|c|c|c|c|c|c|c|}
\hline Variable & $\mathrm{Hu} / \mathrm{Is}$ & Har dware & $\begin{array}{l}\text { Failed } \\
\text { Equi pment }\end{array}$ & Filters & $\begin{array}{c}\text { Fluor inator } \\
\text { sol ids }\end{array}$ & $\begin{array}{c}\text { GPT-SAC } \\
\text { Waste }\end{array}$ \\
\hline No, containers/yr & 503.3 & 154.6 & 16.7 & $35 . .8$ & 34.0 & 130.2 \\
\hline $1 \mathrm{~b} / \mathrm{canister}$ & 2,580 & 2,150 & 2,905 & 1,584 & 2,958 & 1,076 \\
\hline$t t^{3} / v r$ & 10,760 & 3,310 & 357 & 760 & 727 & 2,785 \\
\hline Radiation, R/hr & $<100$ & 20,000 & $<0.05$ & $<0.05$ & 0.4 & $<0.05$ \\
\hline $\mathrm{Ci} / \mathrm{sh}$ ipment & 3,600 & 27.000 & $<5$ & $<5$ & 38 & $<5$ \\
\hline No. shioments & 71.7 & 154.6 & 0.7 & $1.5_{j}$ & 4.8 & 5.57 \\
\hline
\end{tabular}

(a) Values are shown in more significant tiqures than the accuracy of the data to maintain consistency of the calculations.

quantity the 160-gal canister tare weight of $9501 \mathrm{~b}$. The volume of LLW disposed per year ( $\mathrm{ft}^{3} / \mathrm{yr}$ ) is hased on the external volume of a 160 -gal canister $\left(21.4 \mathrm{ft}^{3}\right)$.

The dose rate of decontaminated hulls was estimated from the contained quantity of ${ }^{60} \mathrm{Co}$. It was determined that there are approximately $2 \mathrm{E}-5 \mathrm{Ci}$ of ${ }^{60} \mathrm{Co}$ per $\mathrm{g}$ of hulls. There are $797,700 \mathrm{~g}$ of decontaminated hulls in a 160-gal canister, or $16 \mathrm{C} i$ of ${ }^{60} \mathrm{Co}$. This was estimated by the authors to give a surface dose rate of 75 to $100 \mathrm{R} / \mathrm{hr}$.

For the curie content of the hulls, it was assumed that after decontamination, the predominant radionuclides remaining would he ${ }^{3} \mathrm{H},{ }^{14} \mathrm{C},{ }^{93} \mathrm{Zr}$ and ${ }^{93} \mathrm{~m} h$, and that the quantities of these radionuclides would not change significantly due to decontamination. Marr (1983) specifies that there are about $239, \mathrm{nOn} \mathrm{Ci}$ of these radionuclides per year in the hul1s, which is equivalent to ahout $470 \mathrm{Ci}$ per 160 -gal canister of decontaminated hulls.

It is assumed that decontamination of the fuel hardware has a negligible impact on reducing its surface dose rate. In narr (1983), a 6nח-gal canister of hulls and hardware with a surface dose rate of $4,600 \mathrm{R} / \mathrm{hr}$ contains $620 \mathrm{~kg}$ of hardware. It is estimated that $76 \%$ of this dose rate results from the ${ }^{60} \mathrm{Co}$ contained in the hardware and $24 \%$ results from ${ }^{137} \mathrm{Cs}$, which is removed during decontamination. Therefore the surface dose rate due to the hardware is estimated to be $76 \%$ of $4,600 \mathrm{R} / \mathrm{hr}$, or $3,500 \mathrm{R} / \mathrm{hr}$. There is twice as much weight of low-level hardware in a $16 n$-gal container, and the 160 -gal container is ahout 
3-1/2 times smaller. Therefore it is estimated that the surface dose rate of the low-level hulls canister is 7 times greater than $3,500 \mathrm{R} / \mathrm{hr}$, or is about $20,000 \mathrm{R} / \mathrm{hr}$.

For the curie content of the hardware, it was assumed that the ${ }^{55} \mathrm{Fe},{ }^{60} \mathrm{Co}$, and ${ }^{63} \mathrm{Ni}$ are all in the hardware and that the quantity of these radionuclides remains unchanged after decontamination. Darr (1983) specifies that there are $42,000,000 \mathrm{Ci} / \mathrm{yr}$ of these radionuclides, which result in $27,000 \mathrm{Ci}$ per 160 -gal canister.

The decontaminable failed equipment, filters, and GPT-SAC waste can be decontaminated such that the packaged surface dose rate is less than 0.05 $\mathrm{R} / \mathrm{hr}$. It is estimated that a 160-gal canister of failed equipment, filters, and GPT-SAC waste as LLW would have a curie content of about $0.2 \mathrm{Ci}$. This estimate was obtained by setting up a ratio between dose rates and curie content given in Darr (1983).

The report DOE/LLW-6Td (EG\&G, Inc. 1983) specifies that shielded shipments (hulls and fluorinator solids) contain about $150 \mathrm{ft}^{3}$ of LLW, and shipments of waste requiring no shielding contain about $500 \mathrm{ft}^{3}$ of LLW. The hardware is shipped in a commercial hulls cask and is limited to 1 canister/cask and 1 cask/shipment (Mckee et al. 1984).

It is assumed for Option 5 that the TRU fluorinator solids are mixed with the non-TRU fluorinator solids to form a LLW and that the final surface dose rate is the weighted average based on initial drum volume of all the drums of fluorinator solids blended. The final surface dose rate of the blended fluorinator solids is estimated to be $0.4 \mathrm{R} / \mathrm{hr}$. It was assumed that an estimate of the curie content of the fluorinator solids can be obtained by taking a weighted average based on weight for all the fluorinator solids in stream 41 that are biended together. This results in a content of $38 \mathrm{Ci} / \mathrm{shipment}$.

Table 0.13 gives the unit costs for disposing of the LLW by the different categories of the cost schedule in Appendix E. 
TARLE 0.13. Unit Cost for LLW nisposal by Cost Category

\begin{tabular}{|c|c|c|c|c|c|c|}
\hline Category & $\mathrm{Hul} 15$ & Hardware & Equ i pment & Filters & Solids & $\begin{array}{c}\text { GPT-SAC } \\
\text { Waste }\end{array}$ \\
\hline Disposal, $\$ / t t^{3}$ & 14.50 & 14.50 & 14.50 & 14.50 & 14.50 & 14.50 \\
\hline Radiation, $\$ / f t^{3}$ & 70 & 2,100 & 0 & 0 & 0 & 0 \\
\hline Weight, $\$ /$ container & 250 & 250 & 250 & 250 & 250 & 250 \\
\hline Curies, \$/shipment & 6,000 & 17,600 & 500 & 500 & 1,500 & 500 \\
\hline Perpetuity, $\$ / 4 t^{3}$ & 4.75 & 4.75 & 4.75 & 4.75 & 4.75 & 4.75 \\
\hline $5 C$ LLw tax, $\$ / f t^{3(a)}$ & 4.00 & 4.00 & 4.00 & 4.00 & 4.00 & 4.00 \\
\hline Cask, $\$$ shipment & 500 & 500 & 0 & 0 & 500 & 0 \\
\hline
\end{tabular}

(a) South Carolina LLW tax.

The disposal costs hased on radiation level and curie content for the hardware shipments were extrapolated from the rates given on the rate schedule in Appendix $E$ because the hardware has a high radiation level and curie content. It was assumer that the LLW facility will accept these shipments. A least squares fit of the natural $\log$ of the surface dose rate (and curie content) from the rate schedule in Appendix $E$ versus the associated cost was performed. Plotting these points verified that the cost per shipment increases exponentially with surface dose rate (and curie content). The disposal costs of the hardware shipments were approximated by extrapolating these points to the surface dose rate and curie content associated with the decontaminated hardware.

Table 0.14 gives the disposal costs per year for the LLW from Option 5 by cost category. Also included are the total costs hased on 1,500 MTU and 70,000 MTU.

Some LLW is generated in Option 6 from cementation of the fluorinator solids. The disposal parameters for the fluorinator solids are:

$$
\begin{aligned}
& \text { No. of } 160 \text { gal containers }=94.6 \\
& \text { Weight, } 1 \mathrm{~b} / \text { container }=734+950=1,700 \\
& \text { Volume, } \mathrm{ft}^{3} / \mathrm{yr}=1,984 \\
& \text { Radiation, } \mathrm{R} / \mathrm{hr}=1 / 2 \text { (initial surface dose) }=1 / 2(0.873 \mathrm{R} / \mathrm{hr})=0.44
\end{aligned}
$$


TABLE D.14. Disposal Costs for LLW from Option $5^{(a)}$

\begin{tabular}{|c|c|c|c|c|c|c|c|c|c|}
\hline \multirow[b]{2}{*}{ Category } & \multicolumn{6}{|c|}{ Cost, \$M/yr } & \multicolumn{3}{|c|}{ Total, B/M } \\
\hline & Hulls & Hardware & $\begin{array}{l}\text { Failed } \\
\text { Equidment }\end{array}$ & Filters & $\begin{array}{c}\text { Fluorinator } \\
\text { solids }\end{array}$ & $\begin{array}{c}\text { GPT-SAC } \\
\text { waste }\end{array}$ & 1,500 & MTU & $70,000 \mathrm{MTL}$ \\
\hline Disposal & $\overline{0.156}$ & 0.048 & 0.005 & 0.011 & 0.011 & 0.040 & 0.27 & & 12.6 \\
\hline Radiation & 0.753 & 6.951 & 0 & 0 & 0 & 0 & 7.70 & & $35 y .5$ \\
\hline weight & 0.126 & 0.039 & 0.004 & 0.009 & 0.009 & 0.033 & 0.22 & & 10.3 \\
\hline Curies & 0.430 & 2.721 & 0,0004 & 0.0007 & 0.007 & 0.003 & 3.16 & & 147.6 \\
\hline Perpetuity & 0.051 & 0.016 & 0.002 & 0.004 & 0.003 & 0.013 & 0.09 & & 4.2 \\
\hline SC LLW $\operatorname{tax}(b)$ & 0.043 & 0.013 & 0.001 & 0.003 & 0.003 & 0.011 & 0.07 & & 3.5 \\
\hline Cask & 0.036 & 0.077 & 0 & 0 & 0.002 & 0 & 0.12 & & 5.4 \\
\hline Total & $\overline{1.595}$ & $\overline{9.865}$ & $\overline{0.012}$ & $\overrightarrow{0.028}$ & $\overline{0.035}$ & $\overline{0.100}$ & $\overline{11.63}$ & & $\overline{543.1}$ \\
\hline
\end{tabular}

(a) Values are shown in more significant fiqures than the accuracy of the data to maintain consistency of the calculations.

(b) South Carolina LLW tax.

$$
\begin{aligned}
\mathrm{Ci} / \text { shipment } & =(400 \mathrm{Ci} / 15,136 \mathrm{gal})\left(1,12 ? \mathrm{gal} / 150 \mathrm{ft}^{3}\right)\left(150 \mathrm{ft}^{3} / \text { shipment }\right) \\
& =30
\end{aligned}
$$

No. shiprents $=13 . n$

The disposal costs for the cemented LLW from nption 5 aro riatod in Tahle n.15.

\begin{tabular}{|c|c|}
\hline Category & $\begin{array}{c}\text { Cost (\$) Rased } \\
1,500 \text { MTIl } \\
\text { Reprocessed } \\
\end{array}$ \\
\hline Disposal & 2,000 \\
\hline Radiation & n \\
\hline Weight & $? 3,650$ \\
\hline Curies & 19,500 \\
\hline Perpetuity & 9,400 \\
\hline SC LLW tax $(b)$ & 8,000 \\
\hline Cask & 5,500 \\
\hline Total based on 1,500 MTI reprocessed & 69,050 \\
\hline Total based on 70,000 MTll reprocessed & $3, ? \cap 00,0 \cap 0$ \\
\hline
\end{tabular}

TABLE 0.15. Disposal Costs for LLW from Option 6.d:

(a) Values are shown in more significant figures than the accuracy of the data to maintain consistency of the calculations.

(b) South Carolina LLW tax. 


\section{D.4 REFERENCES}

Clark, L. L. et al. 1983. RECON: A Computer Program for Analyzing Repository Economics. PNL-4466, Pacific Northwest Laboratory, Richland, Washington.

Darr, D. G. 1983. Waste Model Characteristics Study: Evaluation of Reprocessing Waste Est imates. DOE/3156/FR-01, Allied-General Nuclear Services, Barnwell, South Carolina.

EG\&G Idaho. 1983. Directions in Low-Level Radioactive Waste Management, An Analys is of Low-Level Waste Disposal Facility and Transportation Costs. DOE/LLW-6Td, Idaho FaTTs, Idaho.

Mckee, R. W., L. L. Clark, P. M. Daling, J. F. Nesbitt, and J. L. Swanson. 1984. "Economic Analysis of Waste Management System Alternatives for Reprocessing Wastes." Waste Management 1984, pp. 383-393. University of Arizona, Tucson.

McNair, G. W. et al. 1984. Truck and Rail Charges for Shipping Spent Fuel and Nuclear Waste. PNL-4064, Pacific Northwest Laboratory, Richland, Washington.

Rasmussen, D. E. 1982. Comparison of Cask and Drywell Storage Concepts for a Monitored Retrievable Storage/Interim Storage System. PNL-4450, Pacific Northwest Laboratory, Richland, washington.

U.S. Department of Energy. 1979. Technology for Commercial Radioactive Waste Management. DOE/ET-0028 in 5 volumes, U.S. DOE, Washington, D.C.

Wilmot, E. L. et al. 1983. A Preliminary Analysis of the Cost and Risk of Transporting Nuclear Waste to Potential Candidate Commercial Repository Sites. SAND83-0867, Sandia National Laboratories, Albuquerque, New Mexico. 
APPENDIX E

RATE SCHEDULE FOR THE BARNWELL LOW-LEVEL. RADIOACTIVE WASTE DISPOSAL FACILITY 
APPENDIX E

RATE SCHEDULE FOR THE BARNHELL LOW-LEVEL

RADIOACTIVE WASTE DISPOSAL FACILITY $(a)$

A11 radwaste material sha11 comply with Department of Transportation packaging specifications in accordance with Title 49 and Title 10 of the Code of Federal Regulations, CNSI's Nuclear Regulatory Commission and South Carolina Radioactive Material Licenses, CNSI's Rarnwell Site Disposal Criteria, and amendments thereto.

1. DISPOSAL CHARGES: (Not including surcharges)

A. $\$ 14.50$ per cubic foot, but not less than $\$ 300.00$ per shipment

2. SURCHARGES:

A. Radiation Surcharges - steel drums, boxes, and liners:

Maximum Radiation Level at Package Surface $(R / h r)$

$\begin{array}{ccr}0 & - & 0.050 \\ 0.051 & - & 0.100 \\ 0.101 & - & 0.250 \\ 0.251 & - & 0.500 \\ 0.501 & - & 1 \\ 1.001 & - & 5 \\ 5.001 & - & 10 \\ 10.001 & - & 25 \\ 25.001 & - & 50 \\ 50.001 & - & 75 \\ 75.001 & - & 100 \\ 100.001 & - & 125 \\ 125.001 & - & 250 \\ 250.001 & - & 500 \\ 500.001 & - & 1000 \\ 1,000.001 & - & 5000 \\ \text { Greater than } 5000 \mathrm{R} / \mathrm{hr}\end{array}$

Radiation Surcharge (\$ per cubic foot)

No surcharge

$\$ 5.00$

8.00

10.00

13.00

15.00

20.00

30.00

40.00

50.00

70.00

80.00

100.00

200.00

300.00

400.00

By Special Request

(a) This rate schedule, from Chem-Nuclear Systems, Inc., was effective January 1, 1984, and was used to calculate the LLW disposal costs in Appendix 0 . 
B. Weight Surcharges

Wejght of Container

\begin{tabular}{|c|c|c|}
\hline 0 & - & $1,000 \quad 1 \mathrm{~b}$ \\
\hline 1,000 & - & $5,000 \quad 1 b$ \\
\hline 5,000 & - & $10,0001 b$ \\
\hline 10,000 & - & $20,0001 \mathrm{~b}$ \\
\hline 20,000 & - & $30,000 \quad 1 b$ \\
\hline 30,000 & - & $40,0001 \mathrm{~b}$ \\
\hline & - & 50,000 \\
\hline $\mathrm{q} \Gamma \mathrm{\theta}$ & than & $50,0001 \mathrm{~b}$ \\
\hline
\end{tabular}

C. Curie Surcharges:

Curie Content

\begin{tabular}{|c|c|}
\hline 0 & - \\
\hline 1.001 & - \\
\hline 5.001 & - \\
\hline 15.001 & - \\
\hline 25.001 & - \\
\hline 50.001 & - \\
\hline 75.001 & - \\
\hline 100.001 & - \\
\hline 150.001 & - \\
\hline 250.001 & - \\
\hline 500.001 & - \\
\hline $1,000.001$ & - \\
\hline
\end{tabular}

Surcharge Per Container

No Surcha^ge
$\$ \quad 250.000$
500.00
750.00
$1,000.00$
$1,500.00$
$2,000.00$
By Special Request

\section{Surcharge Per Shipment}

$$
\begin{gathered}
\text { No Surcharge } \\
\$ 500.00 \\
750.00 \\
1,000.00 \\
1,500.00 \\
2,000.00 \\
2,500.00 \\
3,000.00 \\
4,000.00 \\
5,000.00 \\
6,000.00 \\
8,000.00
\end{gathered}
$$

By Special Request

D. Biological Tissue Surcharge $\$ 1.00$ per cubic foot

E. Special handling surcharge: Applicable on unusually large or bulky containers

3. CASK HANDLING FEE

$$
\$ 500.00 \text { per cask, }
$$
minimum

4. TAXES AND SPECIAL FUNDS
A. Perpetuity Escrow Fund
$\$ 2.25$ per cubic foot 2.50 per cubic foot effective April 5, 1984

B. S.C. Low Level Radioactive Waste Disposal Tax

$\$ 4.00$ per cubic foot 
C. Barnwell County Business License Tax:

A 2.4\% Barnwell County Business License Tax shall be added to the total of all disposal fees.

NOTE: Fees noted in Iterm $34, A, B$, and $C$ shall be stated separately on all disposal invoices.

5. MISCELLANEOUS:

A. Transport vehicles which are provided with additional shielding features may be subject to a minimum handling fee of $\$ 150.00$ per use. Such a fee covers additional handling and labor required for special equipment set up and temporary shield removal.

B. Decontamination services (if required): $\$ 50.00$ per man-hour plus supplies at current CNSI rate.

C. Customers may be charged for all special services as described in the Barnwell Site Disposal Criteria.

D. Terms of payment are NET 30 DAYS upon presentation of invoices. A service charge per month of the maximum rate permitted by law may be levied on accounts paid after thirty (30) days.

E. Company purchase orders or a written letter of authorization in form and substance acceptable to CNSI shall be received before receipt of radioactive waste material at the Barnwell Disposal Site and shall refer to CNSI's Radioactive Material Licenses, the Barnwell site Disposal Criteria, and subsequent changes thereto.

F. All shipments shall receive a CNSI allocation number and conform to the Prior Notification Plan. Additional information may be obtained at (803) 259-3577 or (803) 259-3578.

G. This Rate Schedule is subject to change and does not constitute an offer of contract which is capable of being accepted by any party.

H. A charge of $\$ 5,000.00$ is applicable to all shipments which require special site set-up for waste disposal. 


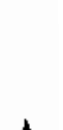


APPENDIX F

ADDITIONAL INFORMATION ON THE EVALULATION OF PROCESSING CHARACTERISTICS 
ADDITIDNAL INFORMATION ON THE EVALUATION OF PROCESSING CHARACTERISTICS

This appendix provides adritional information on the processing characteristics evaluation of the treatment options as presented in Section 9. Tables F.1 through F.4 were developed by the authors after considerable tiscussion of background relating to the factors and qualitative ratings.

Table F.I gives the results of evaluations relating to operational safety. Some abhreviated explanations of the ratings are provided helow.

Option 1 - no treatment - has low accident potential for most operations, since there is no extra handling of the wastes or equipment. However, the waste does contain combustibles and fuel cladding hull fines that may be pyrophoric, and thus the no treatment option does involve some risk of fire.

Option ? - minimum treatment - has a potential for fire or explosion hecause of the potential for generating hull fines and for initiating a pyrophoric chemical reaction during compaction. Since the mechanical compaction presses would be operated remotely, the compaction process would present a low hazard to personnel. The contact handled shredter, however, would provide some mechanical hazard to operating personnel.

Option 3 - minimum number of processes and products - involves incorporating the hulls into cement, thus reducing the fire hazard. Rut this option would also involve some mechanical operations in the proximity of operating personnel for treatment of other waste.

Option 4 - maximum volume reduction without decontamination uses several operations involving high temperatures, the transfer of molten material, and incineration, all of which have an associated fire hazard and radiochemical volatility potential. Shredding and other inechanical handling operations would expose operating 
TABLE F.1. Oualitative Comparison of Relative Operational Safety Among the Six TRlJW Treatment Options (a)

\begin{tabular}{|c|c|c|c|c|c|c|c|}
\hline & $\begin{array}{c}\text { Treatment } \\
\text { Options }\end{array}$ & $\begin{array}{c}\text { Chemical } \\
\text { Hazard }\end{array}$ & $\begin{array}{l}\text { Fire or } \\
\text { Exolosion } \\
\text { Potential }\end{array}$ & $\begin{array}{c}\text { Mechanical } \\
\text { Hazard }\end{array}$ & $\begin{array}{c}\text { Electrical } \\
\text { Hazard }\end{array}$ & $\begin{array}{l}\text { Radiochemica } 1 \\
\text { Release }\end{array}$ & $\begin{array}{c}\text { Overall } \\
\text { Operational } \\
\text { Safety }\end{array}$ \\
\hline 1. & $\begin{array}{l}\text { No } \\
\text { treatment }\end{array}$ & $\begin{array}{l}\text { Very } \\
\text { good }\end{array}$ & Good & $\begin{array}{l}\text { Very } \\
\text { good }\end{array}$ & $\begin{array}{l}\text { Very } \\
\text { gcod }\end{array}$ & $\begin{array}{l}\text { Very } \\
\text { good }\end{array}$ & $\begin{array}{l}\text { Very } \\
\text { good }\end{array}$ \\
\hline 2. & $\begin{array}{l}\text { Minimum } \\
\text { treatment }\end{array}$ & $\begin{array}{l}\text { very } \\
\text { good }\end{array}$ & Maderate & Good & $\begin{array}{l}\text { Very } \\
\text { qcod }\end{array}$ & $\begin{array}{l}\text { Very } \\
\text { good }\end{array}$ & Good \\
\hline 3. & $\begin{array}{l}\text { Minimum } \\
\text { number of } \\
\text { processes }\end{array}$ & Good & Good & Good & $\begin{array}{l}\text { very } \\
\text { good }\end{array}$ & $\begin{array}{l}\text { Very } \\
\text { good }\end{array}$ & Good \\
\hline 4. & $\begin{array}{l}\text { Maximum } \\
\text { vol ume } \\
\text { reduction } \\
\text { without } \\
\text { decon. }\end{array}$ & Good & Fair & Fair & Fair & Fair ${ }^{(b)}$ & Fair \\
\hline 5. & $\begin{array}{l}\text { Maximum } \\
\text { volume } \\
\text { reduction } \\
\text { with decon. }\end{array}$ & Moderate & Fair & Fair & Mcderate & Moderate ${ }^{(b)}$ & Moderate \\
\hline 6. & $\begin{array}{l}\text { Noncombus- } \\
\text { tible waste } \\
\text { forms }\end{array}$ & Good & Moderate & Fair & Hcderate & Fair (b) & Maderate \\
\hline
\end{tabular}

(a) Ratings for each hazard category are relative even though al t the hazards are believed to be acceptable with conventional design and operating practices. Ratings range from very good (most favorable) to fair (least favorable). No attempt is made to determine which hazard cateqory is the most important.

(b) Off-gas systems are available to control radiochemical releases to safe levels.

personnel to some of these hazards. The melting and shredding equipment would use high electrical current usage and would therefore increase this hazard.

Option 5 - maximum volume reduction with recontamination causes some concern about the handling of liquid nitrogen and fuel cladding hulls, since the decontamination operation would generate a fine zirconium powder as material is removed from the hull surface. Some of this fine material would remain as a metal powder and may have pyrophoric tendencies during lag storage and later process operations. Since the melting of the metallic wastes would he avoided, there would he less opportunity for volatilizing the radionuclides. Decontamination residues would still he immobilized, but the quantity 
of material requiring treatment for repository disposal is much less for Option 5 than for the other options. While electrical power requirements will likely he less for 0ption 5 than for the options using melting, the operations will still likely use significant electrical power.

Option 6 - noncombustible waste forms - is similar in part to Option 4 (maximum volume reduction without decontamination), and it therefore has similar safety considerations. However, Option 6 has lower fire and explosion potential because fewer high-temperature processes are utilized and no fuel cladding hull fines are produced. Option 6 would also use less lower electrical power usage than 0ption 4 and would therefore have lower potential electrical hazarts. Since cement is one of the waste forms, there would be some potential for radiolytic gas generation.

The complexity of the treatment processes is compared qualitatively by the number of processes and the number of steps in the process. In general, the more complex the treatment, the greater the cost of the process equipment and the facility space, the greater the likelihood of process upsets and equipment failure, and therefore the lower the operating efficiency of the process as a whole. For this assessment, two measures of process complexity were determined and are shown in Table F.2. The two measures consist of the number of major process units required and the number of major flowsheet steps shown in Section 7 for each of the respective treatment strategies. In the last column in Table F.?, the process simplicity (i.e., inverse of complexity) is derived and is given in Table 9.2.

The status of technology in this study was qualitatively classified by the stage of development of the hardware: conceptual, laboratory or bench scale, nonradioactive pilot or engineering scale, or radioactively operational. This distinction, based on the knowledge of the authors and on review of the literature, is shown in Table F.3. The judgments are hased primarily on the use of the process for the specific wastes of interest in this study and the state of development of the equipment; previous applications of the technology to waste treatments are also recognized. In the last column of Table F.3, the overall qualitative rating is terived and is given in Table 9.?. 
TARLE F.?. Oualitative Comparison of Relative Process Simplicity for the Six TRUW Treatment Options

\begin{tabular}{|c|c|c|c|c|}
\hline & Treatment Option & Process Units (a) & $\begin{array}{l}\text { Number of Steps } \\
\text { in Flowsheet }\end{array}$ & $\begin{array}{c}\text { Overall } \\
\text { Simplicity (c) } \\
\end{array}$ \\
\hline & No treatment & None & 1 & very good \\
\hline 2. & Minimum treatment & $\begin{array}{l}\mathrm{RH} \text { compactor } \\
\mathrm{RH} \text { size reduction } \\
\mathrm{CH} \text { size reduction }\end{array}$ & 7 & Good \\
\hline 3. & $\begin{array}{l}\text { Minimum number of } \\
\text { processes and } \\
\text { products }\end{array}$ & $\begin{array}{l}\text { CH shredder } \\
\text { RH shredder } \\
\text { RH in-drum cement mixer } \\
\text { RH external cement mixer }\end{array}$ & 9 & Good \\
\hline 4. & $\begin{array}{l}\text { Maximum volume } \\
\text { reduction without } \\
\text { decontamination }\end{array}$ & $\begin{array}{l}\text { RH melter for metals and ceramics } \\
\text { RH shredder } \\
\text { RH incinerator } \\
\text { RH las-temperature, hot press }\end{array}$ & 12 & Moderate \\
\hline 5. & $\begin{array}{l}\text { Maximum volume } \\
\text { reduction with } \\
\text { decontamination }\end{array}$ & $\begin{array}{l}\text { Hull cryogenic cracker } \\
\text { RH centrifugal barrel finisher } \\
\text { RH compactor } \\
\text { RH shredder } \\
\text { RH blender } \\
\text { RH vibratory finisher } \\
\text { RH incinerator } \\
\text { LLH cement mixer } \\
\text { CH precipitator } \\
\text { RH high-temperature hot press } \\
\text { (Option 5B on Iv) }\end{array}$ & 15 & Fair \\
\hline 6. & $\begin{array}{l}\text { Honcombustible } \\
\text { waste forms }\end{array}$ & $\begin{array}{l}\text { RH melter for metals } \\
\text { CH shredder } \\
\text { RH shredder } \\
\text { RH incinerator } \\
\text { RH in-drum cement mixer }\end{array}$ & 11 & Moderate \\
\hline
\end{tabular}

(a) An effective assay system is required for each option. Scitting is not shown as a process unit but ill be required for several options.

(b) Taken from Section 7 .

(c) The relative ratings are from very good (the most favorable) to fair (the least favorable in the group).

(d) May already be available in the existing LLw treatment facility.

A qualitative comparison was made of the flexihility of the processes to handle a variety of waste characteristics. This was done hy first qualitatively evaluating the flexibility of each process step, as shown in the Column 3 of Table F.4. In the last column of Tahle F.4, the overall qualitative rating is derived and is given in Tahle 9.2. 


\section{TABLE F.3. Oualitative Comparison of the Status of Technology for the Six TRIJW Treatment Options}

Treatment Option

1. No treatment

2. Minimum treatment

3. Minimum number and products

4. Maximum volume reduction without decontamination

5. Maximum volume reduction with decontamination of processes

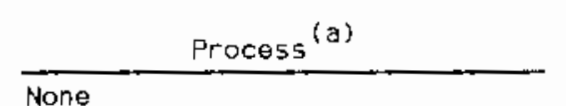

RH compactor

$\mathrm{CH}$ size reduction

$\mathrm{RH}$ size reduction

\section{$\mathrm{CH}$ shredder}

$\mathrm{RH}$ shredder

$\mathrm{RH}$ in-drum cement mixer

RH external cement mixer

$\mathrm{RH}$ melter

RH shredder

RH incinerator

RH low-temperature hot press

Hull cryogenic cracker

RH centrifugal barrel finisher

$\mathrm{RH}$ compactor

$\mathrm{RH}$ shredder

RH blender

RH vibratory finisher

RH incinerator

LLW cement mixer ${ }^{(C)}$

Precipitator

$\mathrm{RH}$ high-temperature hot press (Option 5B only)

6. Noncombustible waste forms

\author{
RH melter for metals \\ $\mathrm{CH}$ shredder \\ RH shredder \\ $\mathrm{RH}$ incinerator \\ $\mathrm{RH}$ in-drum cement mixer
}

\begin{tabular}{|c|c|}
\hline Status of Technology & $\begin{array}{l}\text { Overal! } \\
\text { Status (b) }\end{array}$ \\
\hline Operational & Very good \\
\hline $\begin{array}{l}\text { Operationa! } \\
\text { Operational } \\
\text { Cold pilot scale }\end{array}$ & Very good \\
\hline $\begin{array}{l}\text { Operational } \\
\text { Cold pilot scale } \\
\text { Operational } \\
\text { Operational }\end{array}$ & very good \\
\hline $\begin{array}{l}\text { Cold pilot scale } \\
\text { Cold oilot scale } \\
\text { Contact operational } \\
\text { Conceptual }\end{array}$ & Moderate \\
\hline $\begin{array}{l}\text { Conceptual } \\
\text { Bench scale } \\
\text { Operational } \\
\text { Contact operational } \\
\text { Operational } \\
\text { Cold dilot scale } \\
\text { Contact operational } \\
\text { Operational } \\
\text { Conceptual } \\
\text { Laboratory scale }\end{array}$ & Fair \\
\hline $\begin{array}{l}\text { Cold pilot scale } \\
\text { Operational } \\
\text { Cold pilot scale } \\
\text { Contact operational } \\
\text { Operational }\end{array}$ & Good \\
\hline
\end{tabular}

Operational

Operational

Operational

cold ollot scale

Contact operationa

Operational

Cold dilot scale

Contact operationa

operationa

Conceptual
Cold pilot scale

\footnotetext{
(a) An effective assay system is required for each of the options.

(b) The relative ratings are from very good (the most favorable) to fair (the least favorable in the group).

(c) May already be available in the existing LLW treatment facility.
} 
TABLE F.4. Oualitative Comparison of Process Flexibility for the Six TRUW Treatment Options

\begin{tabular}{|c|c|c|c|c|}
\hline \multicolumn{2}{|r|}{ Treatment option } & Process Units (a) & $\begin{array}{l}\text { Flexibiltty of } \\
\text { Process Steps }\end{array}$ & $\begin{array}{l}\text { Overall Process } \\
\text { Flexibility }\end{array}$ \\
\hline & No treatment & None & Very good & Very good \\
\hline 2. & Minimum treatment & $\begin{array}{l}\text { RH compactor } \\
\mathrm{CH} \text { size reduction } \\
\text { RH size raduction }\end{array}$ & $\begin{array}{l}\text { Good } \\
\text { Very good } \\
\text { Good }\end{array}$ & Good \\
\hline & $\begin{array}{l}\text { Minimum number of } \\
\text { processes and } \\
\text { products }\end{array}$ & $\begin{array}{l}\mathrm{CH} \text { shredder } \\
\mathrm{RH} \text { shredder } \\
\mathrm{RH} \text { in-drum cement mixer } \\
\mathrm{RH} \text { external cement mixer }\end{array}$ & $\begin{array}{l}\text { Good } \\
\text { Good } \\
\text { Very good } \\
\text { Very good }\end{array}$ & Good \\
\hline & $\begin{array}{l}\text { Maximum volume } \\
\text { reduction without } \\
\text { decontamination }\end{array}$ & $\begin{array}{l}\text { RH melter } \\
\text { RH shredder } \\
\text { RH incinerator } \\
\text { RH low-temperature hot press }\end{array}$ & $\begin{array}{l}\text { Good } \\
\text { Good } \\
\text { Fair } \\
\text { Fair }\end{array}$ & Fair \\
\hline & $\begin{array}{l}\text { Maximum volume } \\
\text { reduction ith } \\
\text { decontamination }\end{array}$ & $\begin{array}{l}\text { Hull cracker } \\
\text { RH centrifugal barral finisher } \\
\text { RH compactor } \\
\text { RH shredder } \\
\text { RH blender } \\
\text { RH vibratory finisher } \\
\text { RH incinerator } \\
\text { LLW cement mixer (c) } \\
\text { Precipitator } \\
\text { RH high-temperature hot press } \\
\text { (Option 5B on iy) }\end{array}$ & $\begin{array}{l}\text { Fair } \\
\text { Fair } \\
\text { Good } \\
\text { Good } \\
\text { Good } \\
\text { Fair } \\
\text { Fair } \\
\text { Very good } \\
\text { Good } \\
\text { Fair }\end{array}$ & Fair \\
\hline & $\begin{array}{l}\text { Noncombustible } \\
\text { waste forms }\end{array}$ & $\begin{array}{l}\text { RH metallic melter } \\
\text { CH shredder } \\
\text { RH shredder } \\
\text { RH inctnerator } \\
\text { RH in-drum cement mixer }\end{array}$ & $\begin{array}{l}\text { Good } \\
\text { Good } \\
\text { Good } \\
\text { Fair } \\
\text { Very good }\end{array}$ & Good \\
\hline
\end{tabular}

(a) An effective assay system is required for each option.

(b) The relative ratings are from very good (the most favorable) to fair (the least favorable in the groupl.

(c) May already be available in the existing LLw treatment facility. 


\section{DISTRIBUTION}

No. of

Copies

OFFS ITE

7 DOE Office of Terminal Waste GTN

Washington, DC 20545

ATTN: J. E. Baublitz, NE-24

J. A. Coleman, NE-25

ก. J. McGoff, NE-23

J. A. Turi, NE-25

W. R. Voigt, NE-20

H. F. Walter, NE-25

J. R. Zorn, NE-25

30 DOE Technical Information Center

5 Geologic Repository Division DOE Office of Civilian

Radioactive Waste Management Forrestal Building

Washington, DC 20545

ATTN: J. W. Bennett, RW-20

C. R. Cooley, RW-4

M. W. Frei

R. Rusche, RW-1

R. Stein, RW-23

2 DOE Office of Defense Waste \& Byproducts Management GTN

Washington, DC 20545

ATTN: D. R. LeClaire, DP-12

R. ก. Walton, Jr., DP-12.3

M. J. Beli

Division of Nuclear Materials

Safety \& Safeguards

Mail Station 881-SS

Nuclear Regulatory Commission

washington, nC 20555

A. T. Clark

Division of Fuel Material Safety

Nuclear Regulatory Commission

Washington, П.C. 20555
No. of

Copies

W. J. Dircks

Office of the Executive

Director for Operations

Mail Station 6209

Nuclear Regulatory Commission

Washington, nC 20555

2 Environmental Protection Agency

Office of Radiation Programs

401 M. Street, S.W.

Washington, DC 20460

ATTN: D. Egan

G. L. Sjoblom

2 DOE ATbuquerque Operations

Office

P.0. Box 5400

Albuquerque, NM 87185

ATTN: R. Y. Lowrey

J. McGough

W. H. Hannum

DOE West Valley Operations

Office

P. O. Box 191

West Valley, NY 14171

2 DOE Idaho Operations Office

550 Second Street

Idaho Falls, In 83401

ATTN: J. D. Hamric

J. B. Whitsett

L. Lanni

DOE San Francisco Operations

1333 Broadway

San Francisco, CA 94612

W. E. Pasko

DOE Dak Ridge Dperations Office

P.O. Box E

nak Ridge, TN 37830

S. A. Mann

DOE Chicago Operations Office

gann South Cass Avenue

Argonne, IL 60439 
No. of

Copies

J. 0 . Neff

DOE National Waste Program office

505 King Avenue

Columbus, $\mathrm{OH} 43201$

G. K. Dertel

DOE Savannah River Operations Office

P.0. Box A

Aiken, SC 29801

D. L. Vieth

DOE Nevada Operations Office

P.0. Box 14100

Las Vegas, NV 89114

2 Argonne National Laboratory

9700 South Cass Avenue

Argonne, Il. 60439

ATTN: C. S. Abrams/ J. H. Kittel

M. J. Steindler/

L. E. Trevorrow

5 Battelle Memorial Institute Project Management Division $505 \mathrm{King}$ Avenue

Columbus, $\mathrm{OH} 43201$

ATTN: W. A. Carbeiner/

S. H. Basham

J. F. Kircher

B. Rawles

W. J. Madia

H. J. Peters

F. Holzer

Lawrence Livermore National Laboratory

University of California

P.0. Box 808

Livermore, CA 94550
No. of

Copies

D. T, Oakley

Los Alamos Scientific

Laboratory

MS 671

P.0. Box 1663

Los Alamos, NM 87544

T. H. Row

Oak Ridge National Laboratory

P.0. Box $X$

0ak Ridge, TN 37830

3 Oak Ridge National Laboratory

P.0. Box Y

Oak Ridge, TN 37830

ATTN: J. 0. Blomeke

W. D. Burch

L. A. Dole

5 Sandia Laboratories

P.0. Box 5800

Albuquerque, NM 87185

ATTN: D. R. Andercon

R. W. Lynch

J. F. Ney

W. Weart

Technical Library

B. R, Wheeler

Westinghouse Idaho Nuclear

Co., Inc.

P.0. Box 4000

Idaho Falls, ID 83401

6 E. I. du Pont de Nemours

\& Company

Savannah River Laboratory

Aiken, SC 29801

ATTN: $M$. D. Borsma

J. L. Crandal?

E. J. Henneliy

L. L. Kilpatrick/L. M. Lee

S. Mirshak

R. M. Wallace 
No. of

Copies

E. A. Jennrich

EGRG Idaho

P.0. Box 1625

Idaho Falls, in 83415

K. V. Gilbert/P. G. hagen

Rockwell International

Rocky Flats Plant

$P .0$. Box 464

Golden, C0 80401

G. W. Meyers

Atomics International nivision

Rockwell International

8900 DeSoto Avenue

Canoga Park, CA 91304

T. H. Pigford

Department of Nuclear

Engineering

University of California

Berkeley, CA 94720

M. E. Spaeth

Science Applications, Inc.

2769 South Highland

Las Vegas, NV 89109

J. F. Strahi

Roy $F$. Weston, Inc. 23D1 Research Boulevard

Rockville, MD 20850

R. F. Williams

Electric Power Research

Institute

3412 Hillview Avenue

P.O. Box 10412

Palo Alto, CA 94304
No. of

Copies

6 West Valley Nuclear Services Company

P.0. Box 191

A1buquerque, N"1 87185

ATTN: C. C. Chapman

J. C. Chyner

L. R. Fisenstatt

J. L. Knabenschuh

J. E. Krauss

J. M. Pope

J. W. Bartlett

The Analytic Sciences

Corporation

6 Jacoh Way

Reading, MA 01867

W. A. Freeby/J. L. Jardine

Bechtel National, Inc.

P.0. Box 3965

San Francisco, CA 94119

Librarian

Westinghouse Electric

Corporation

Technical Library

P.0. Box 40039

Albuquerque, NM 87196

L. L. Hench

Department of Materials Science \& Engineering

University of Florida

Gainesville, FL 32611

J. L. Larocca, Chairman

Energy Research \& Development Authority

Empire State Plaza

Albany, NY 12???3

R. G. Post

College of Engineering

Iniversity of Arizona

Tucson, AZ $857 ? 1$ 
No. of

Copies

ONSITE

6 DOE Richland Operations Office

J. H. Anttonnen/P. A. Craig

E. A. Bracken

H. E. Ransom

J. L. Rhoades

M. W. Shupe

J. D. White

11 Rockwel1 Hanford Operations

E. B. Ash

K. A. Gasper

R. N. Gurley

J. W. Patterson

R. D. Prosser

J. H. Roecker

K. R. Shah

M. J. Smith

T. B. Veneziano

D. 0. Wodrich

File Copy

UNC United Nuclear Industries

T. E. Dabrowski/W. J. Kyriazis

2 Westinghouse Hanford Company

R. E. Lerch

J. D. Watrous

60 Pacific Northwest Laboratory

R.P. Allen

W. J. Bjork lund

W. F. Bonner

D. J. Bradley

H. C. Burkholder

J. R. Carrell

L. A. Chick

T. D. Chikalla

P. M. Daling

R. M. Fleischman

J. H. Jarrett/C.A. Geffen

Y. B. Katayama
No, of

Copies

$\frac{\text { Pacific Northwest Laboratory }}{\text { (contd) }}$

S. E. King

D. E. Knowlton

W. L. Kuhn

L. T. Lakey/K. M. Harmon

J. M. Latkovich

R. C. Lijkala/M. R. Kreiter

J. L. McElroy

R. W. Mckee

G. B. Mellinger

J. E. Mendel/M. D. Merz

J. E. Minor

D. R. Mont gomery

R. D. Peters

A. M. Platt

J. V. Robinson

W. A. Ross (10)

K. J. Schnei der (10)

S. C. Slate

J. L. Swanson

R. L. Treat

G. L. MeVay

J. H. Westsik

W. R. Wiley/D. B. Cearlock/ R. P. Marshall

Technical Information (5)

Publishing Coordination MA (2) 